

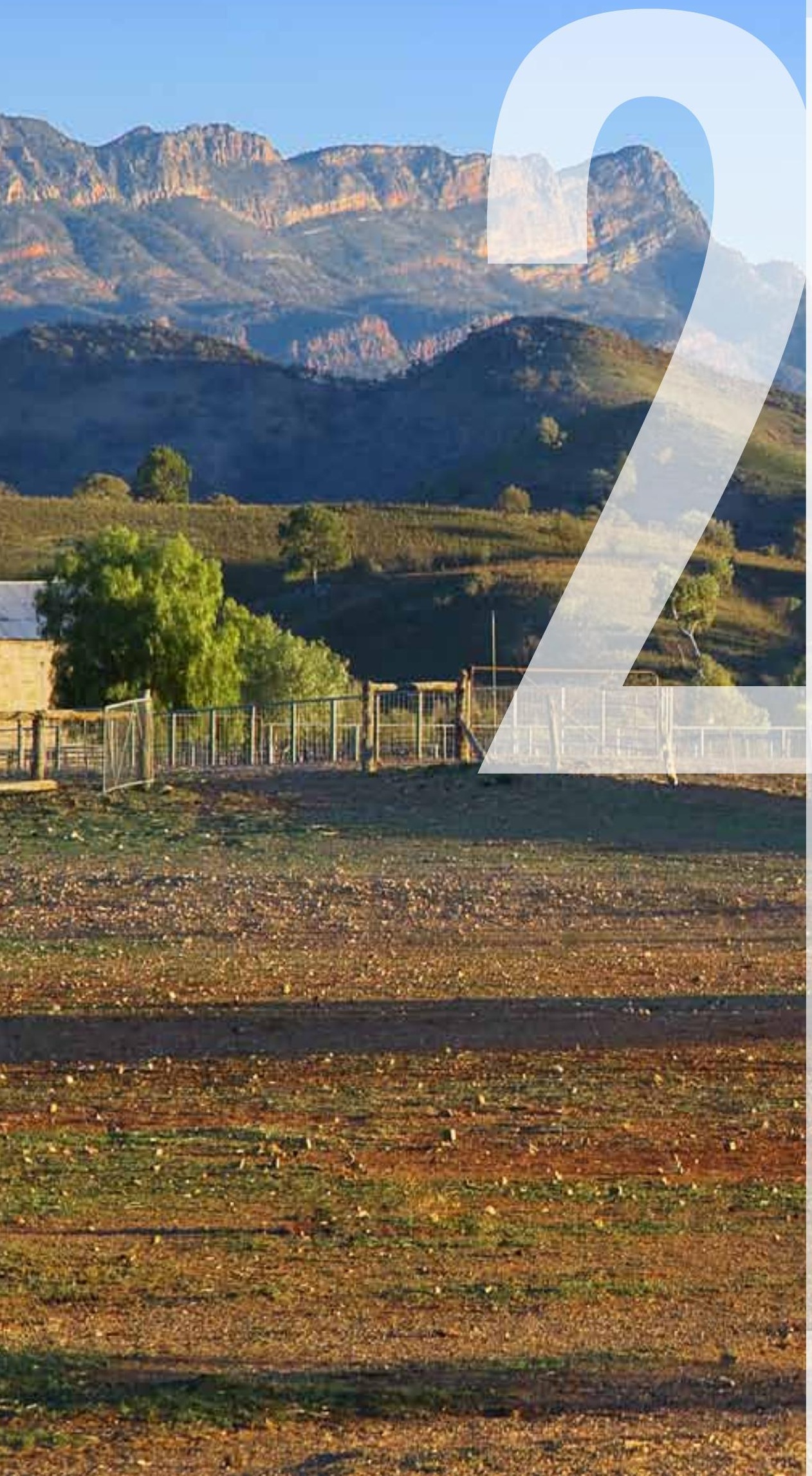

\section{Australia in time and space}

The geology of Australia has exerted a fundamental influence on the welfare and lives of the Australian people and their economic and environmental sustainability. How did Australia's remarkable geology develop, from its deep-time roots in the Archean to the present, and how has this development affected the distribution and abundance of Australia's economic and environmental resources? This chapter provides a summary of Australia's geology in terms of time and space-how Australia was assembled and how it interacted with other continents to produce a rich geology, flora, fauna and landscape. Australia, as a nation continent, has been systematically mapped, and numerous geological and geophysical maps and datasets are available to advance our understanding of the continent.

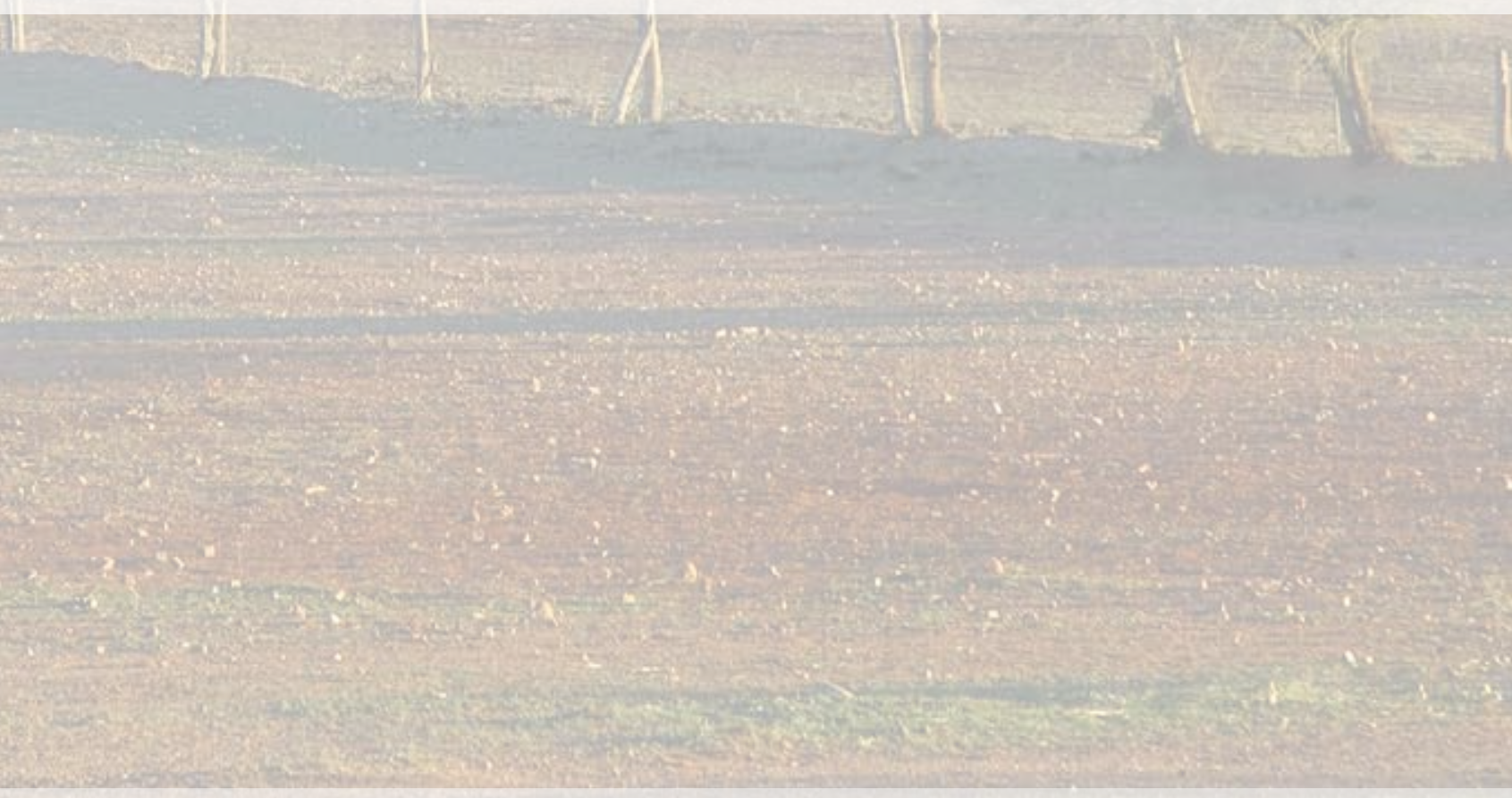

Richard S Blewett, ${ }^{1}$ Brian LN Kennett ${ }^{2}$ and David L Huston ${ }^{1}$

${ }^{1}$ Geoscience Australia, ${ }^{2}$ Australian National University 


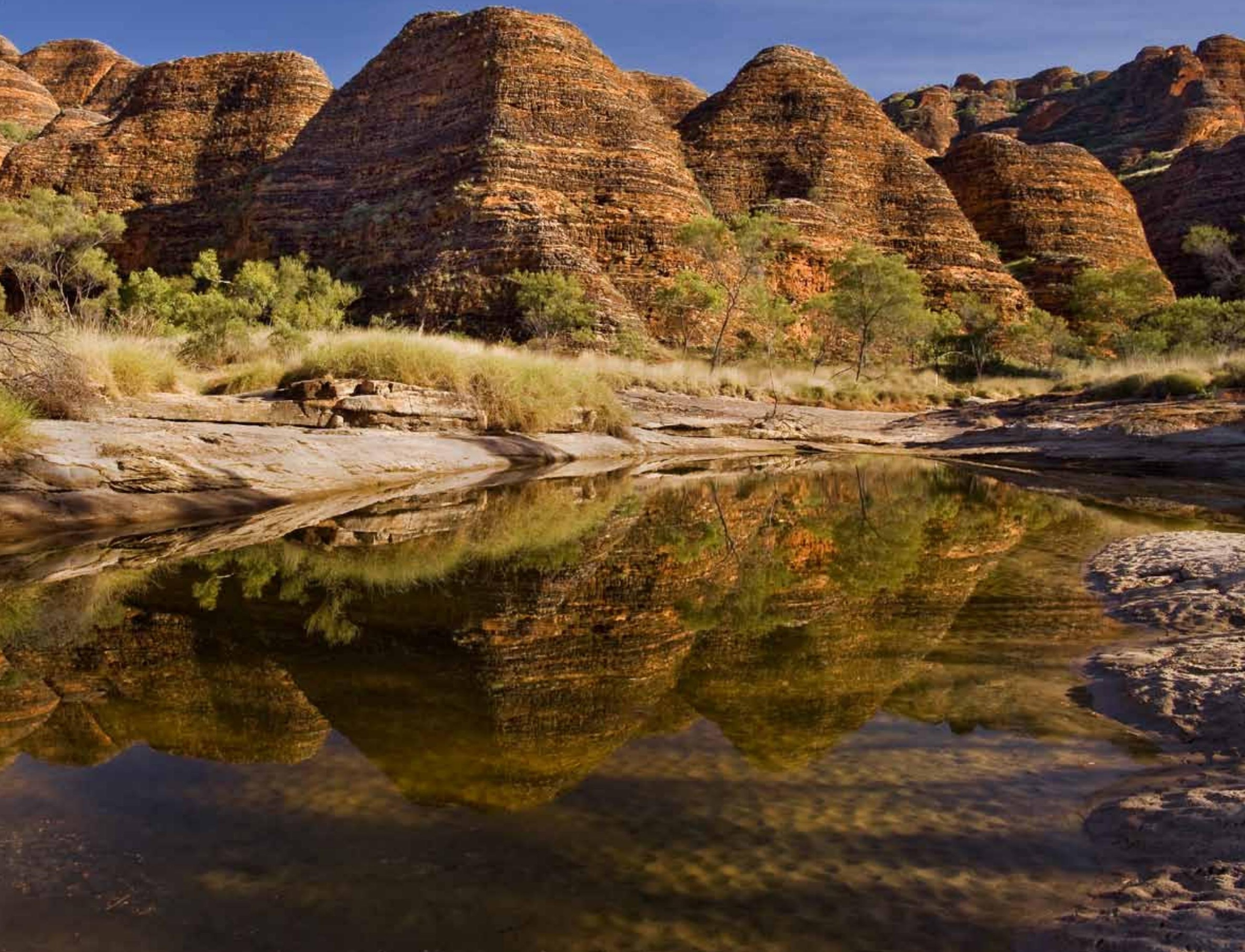




\section{Australia's current tectonic setting}

\section{Plate boundaries}

Globally, there are 14 large and about 40 small tectonic plates, ranging in size from the Pacific Plate, which comprises $20.5 \%$ of Earth's surface, to the Manus Microplate in the Bismarck Sea, which comprises only $0.016 \%$ of the surface area. These tectonic plates are thought to be nearly rigid blocks of lithosphere, defined by their boundaries and their trajectory across Earth's surface. The plate boundaries can be convergent, or divergent, or transform. Increasingly evident are regions of diffuse seismicity, with wide, slowly deforming boundaries (as opposed to sharp, discrete ones) between some plates.

Australia was once thought of as simply part of the rapidly moving Indo-Australian Plate, but is now considered as a plate in its own right (Figure 2.1). The Australian Plate appears to be rigid from Cocos Island in the west to Noumea in the east and incorporates the entire Australian continent. The smaller Capricorn Plate is located between the Indian Plate to the northwest and the Australian Plate to the east and southeast. The small Macquarie Microplate is thought to have existed for

Western Australia.

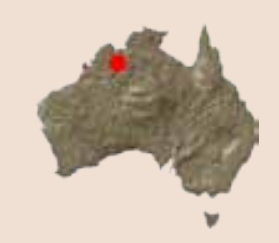

ca $6 \mathrm{Ma}$. It is a further subdivision of the former Indo-Australian Plate, and is located to the east of the Tasman Fracture Zone.

The boundary forces acting upon the Australian Plate vary, from extension in the south and southwest to compression in the east and north. To the south, an active spreading centre, the Southeast Indian Ridge, separates the Antarctic Plate from the Australian Plate (Figure 2.1). This southern plate boundary, a mid-ocean ridge, was around $100 \mathrm{Myr}$ in the making and developed with the breakup of Gondwana (Chapter 4). Australia's motion was initially to the northwest, but a major plate reorganisation occurred in the Pacific Ocean between $53 \mathrm{Ma}$ and $50 \mathrm{Ma}$, possibly caused by subduction of the Pacific-Izanagi

The Australian Plate boundary bisects New Zealand, here as the Alpine Fault.

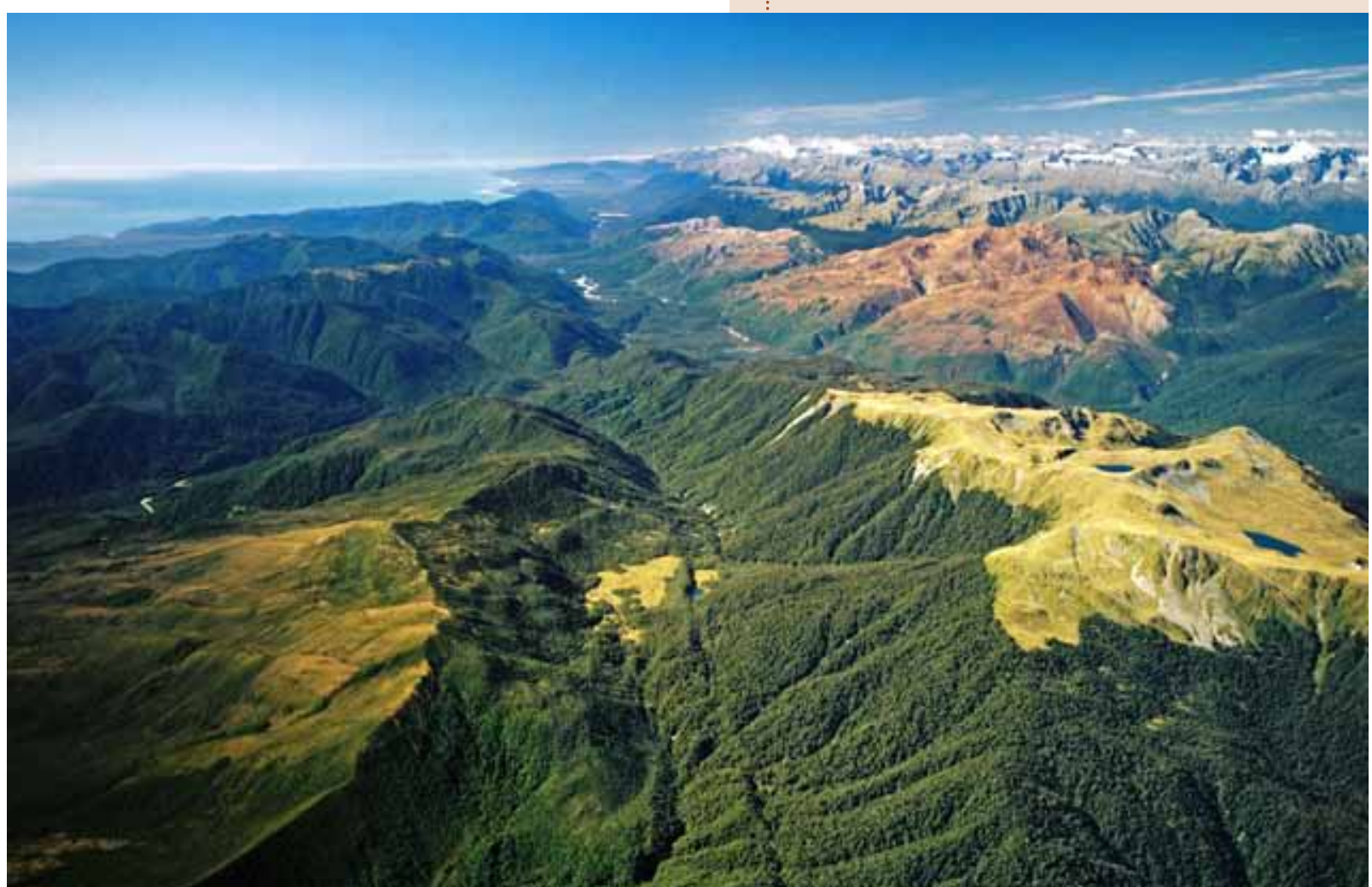




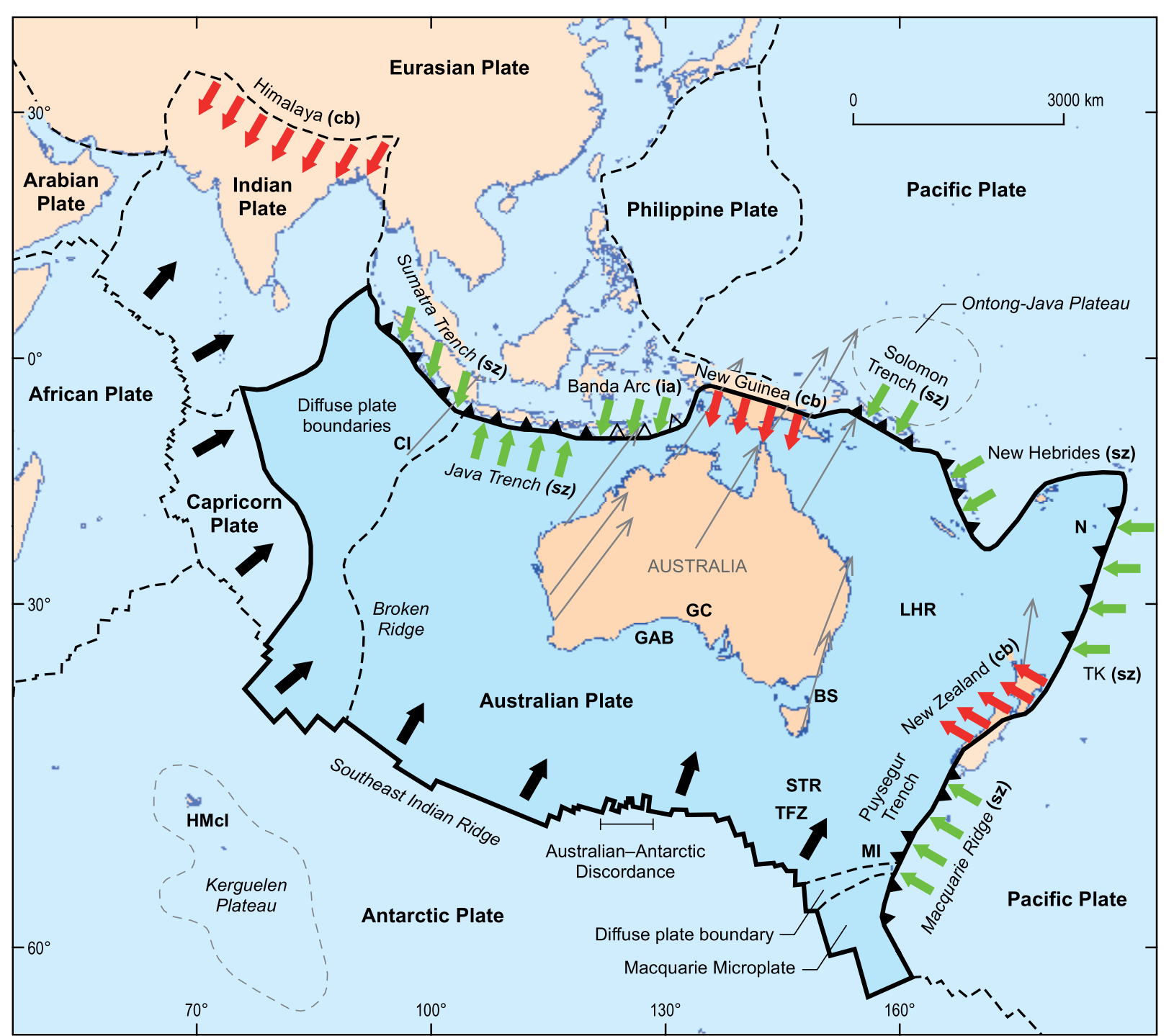

- Australian Plate boundary

--- Plate boundary

Plateau boundary

$\longrightarrow$ GPS track

Figure 2.1: Map of the crustal plates and their key boundaries surrounding the Australian Plate. The Capricorn Plate is a zone of diffuse seismicity between the Indian and Australian plates. Red arrows are the plate motion vectors and velocity. GPS measurements show that Australia is moving to the north-northeast at a rate of around $7 \mathrm{~cm}$ per year. The Australian-Antarctic Discordance is a region where the mid-ocean ridge between Antarctica and Australia is anomalously deep. (Sources: modified from Rover \& Gordon, 1997; Tregoning, 2003; DeMetts et al., 2010

$\mathrm{BS}=$ Bass Strait; $\mathrm{Cl}=$ Cook Islands; $\mathrm{GAB}=$ Great Australian Bight; GC = Gawler Craton; LHR = Lord Howe Rise; HMcl = Heard and McDonald Islands; $\mathrm{MI}=$ Macquarie Island; STR = South Tasman Rise; TFZ = Tasman Fault Zone spreading ridge and subsequent Marianas/ Tonga-Kermadec subduction initiation. Whatever the cause, Australia's drift direction changed to its present north-northeast trajectory. Full separation between Australia and Antarctica was not achieved until $34 \mathrm{Ma}$. Australia has migrated more than $3000 \mathrm{~km}$ along this north-northeast path at a rate of 6-7 $\mathrm{cm}$ per year, making it the fastest moving continent. The final separation from Gondwana saw the emergence of the island continent that we recognise as Australia (Chapter 4), and marks a significant point in the evolutionary path of our geology and landscape (Chapter 5) and of our distinctive flora and fauna (Chapter 3).

The eastern boundary of the Australian Plate with the Pacific Plate is a collisional zone through New Zealand and a clear subduction boundary along the Tonga-Kermadec Trench north of New Zealand. The Australian Plate is being subducted beneath the Pacific Plate along its northeastern margin at the New Hebrides and Solomon trenches, and again beneath the South Island of New Zealand at the Puysegur Trench. The northern boundary is tectonically complex. Australia is colliding with the Pacific Plate through the island of New Guinea. Further west, the interaction is with the Eurasian Plate, with collision occurring in the Banda Arc region and subduction beneath Indonesia at the Java and Sumatra trenches. The western plate boundary is formed by a diffuse zone of seismicity with the Capricorn Plate (Figure 2.1).

\section{Stress state}

The forces generated at the plate boundaries are transmitted across the plates. These forces originate from at least three types of settings: the 
subduction of oceanic lithosphere, collision zones between continental lithosphere, and seafloor spreading (ridge push). Analysis of earthquakes generated at these boundaries and within the plate can be used to determine the type, magnitude and direction of stress. These earthquakes are also sources of energy that can be used to map the structure of the lithosphere and asthenosphere (see later). Other sources of stress are generated from the gravitational potential inherent in the mass distribution within the plate itself and within the mantle, which is reflected in the shape of the gravitational equipotential surface known as the geoid. Beneath continental Australia, the geoid slopes downwards to the southwest, with a total fall of around $125 \mathrm{~m}$.

Continental Australia is unique among the continents in that the measured stress field is not parallel to the present day north-northeast directed plate motion (Figure 2.2). Much of continental Australia is under a horizontal compressional stress (Did you know? 2.1), and most of that stress state is controlled by compression originating from the three main collision boundaries located in New Zealand, Indonesia and New Guinea, and the Himalaya (transmitted through the Indian and Capricorn plates). South of latitude $-30^{\circ}$, the stress trajectories are oriented east-west to northwest-southeast. North of this latitude, the stress trajectories are closer to the present-day plate motion, being oriented east-northeast-westsouthwest to northeast-southwest. Notably, the main stress trajectories diverge most markedly from one another in north-central New South Wales (Figure 2.2).

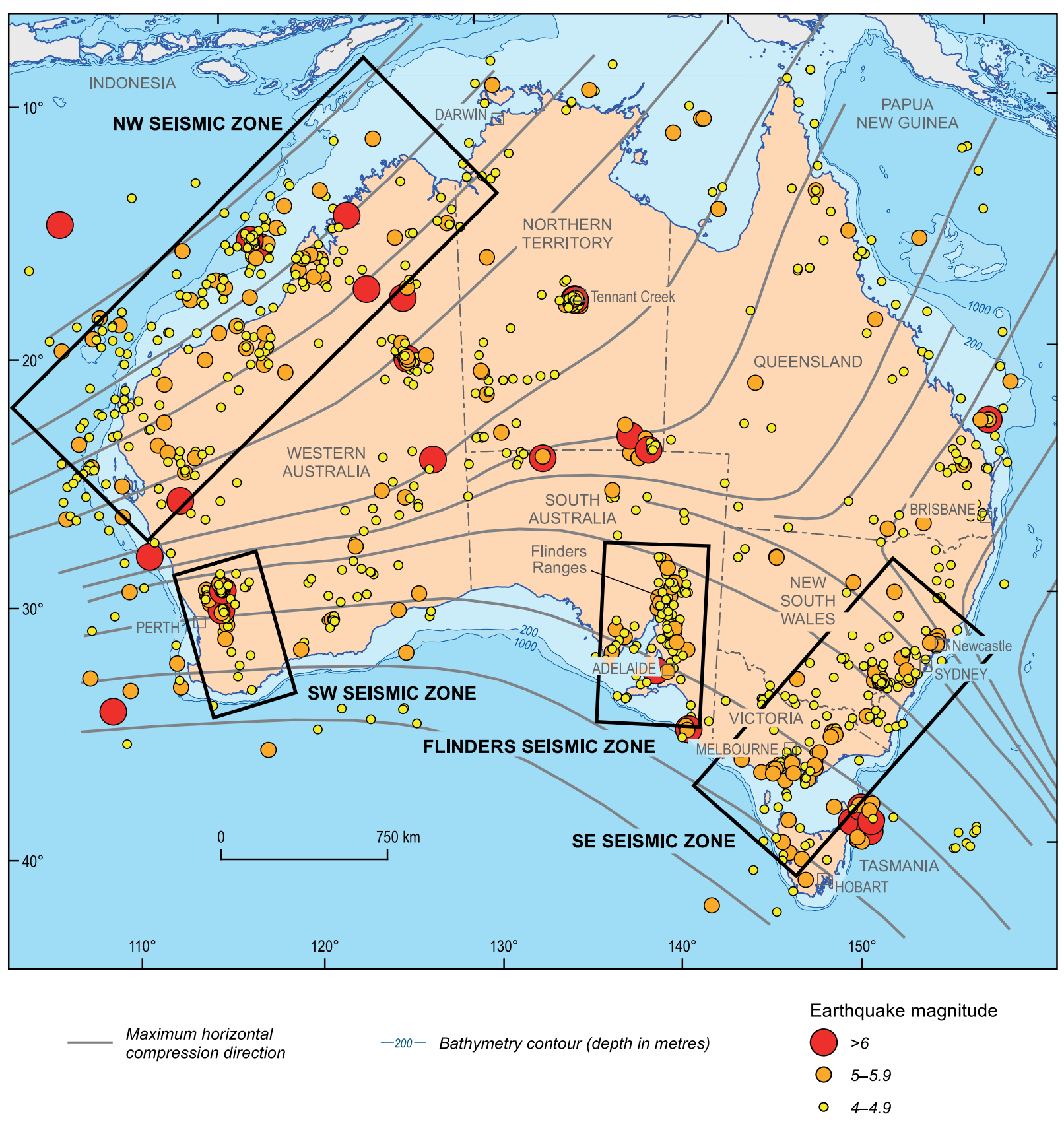

Figure 2.2: Distribution of magnitude $M>4$ historical earthquake epicentres, mapped neotectonic (young) features (modified from Quigley et al., 2010), and directions of maximum horizontal compression (SHmax), shown as grey lines (after Hillis \& Reynolds, 2003). The directions of maximum horizontal compression sweep east-west across the southern half of the continent and diverge to northeast and north-northeast over the northern half of the continent. Australia is divided into four main seismic zones: NW Seismic Zone, SW Seismic Zone, Flinders Seismic Zone and SE Seismic Zone. One of the most active seismic provinces is located in the Flinders Ranges of South Australia. This region coincides with recent uplift of the landscape (Chapter 5) and a zone of enhanced heat flow (Chapter 10). 


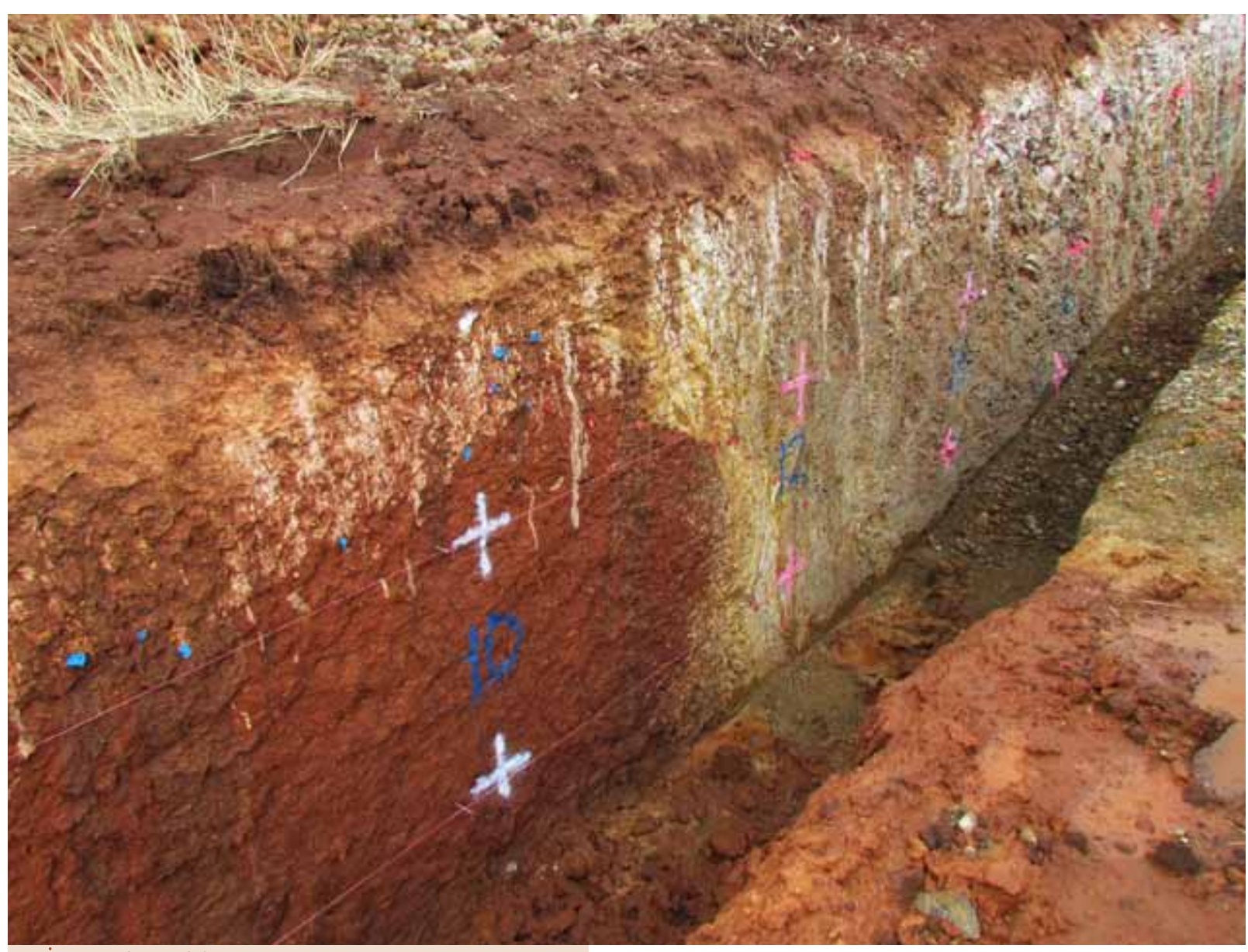

Image by Dan Clark

O Trench exposure, showing Proterozoic Burra Group bedrock (grey) thrust over Pleistocene alluvial sediments (red) across the Williamstown-

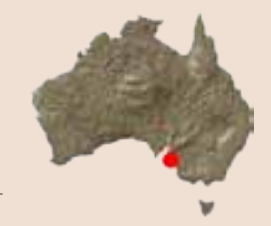
Meadows (Kitchener) Fault, northern Mt Lofty Ranges, South Australia. The most recent large earthquake event on this fault, some $30-40 \mathrm{ka}$, resulted in the formation of a scarp $>25 \mathrm{~km}$ long and $1.5 \mathrm{~m}$ high.
For what is generally considered a 'stable' intraplate continental region, Australia experiences a relatively high level of seismicity. The distribution of events with magnitude $M \geq 5.5$ is not uniform across the continent. Rather, the largest earthquakes are clustered into four main regions, which have contrasting basement ages (Archean, Proterozoic and Paleozoic). These seismic zones are characterised by normally low seismic activity punctuated by a period of enhanced seismic activity associated with one or more large earthquakes over decadal time-scales. There is some spatial overlap between such clusters of seismicity and mapped neotectonic reactivation of ancient fault zones and/or regions of elevated crustal heat flow. These spatial relationships suggest that active intraplate deformation in Australia is guided most likely by prior tectonic structures and local to regional thermal weakening of the lithosphere.

The Flinders Seismic Zone in South Australia is one of the most seismically active regions in Australia, with earthquakes of magnitude up to M 6.5 recorded. Interestingly, this region lies within the South Australian Heatflow Anomaly, comprising some of the world's highest concentrations of heat-producing elements (Chapter 10). Major fault displacements, with the uplift of the Mt Lofty Ranges to more than $700 \mathrm{~m}$ asl, are a testament to the tectonic activity in this region. In a number of localities, such as the Wilkatana Fault in the central Flinders Ranges, east- and west-directed thrust faults place Precambrian basement rocks over Pleistocene sediments as young as $30 \mathrm{ka}$. Earthquake focal-mechanism solutions for this zone additionally indicate strike-slip and reverse mechanisms, with a broadly east-west oriented maximum horizontal stress orientation. Quaternary tectonism in southeastern South Australia also resulted in the damming of the Murray River and formation of a large inland lake that persisted for $500 \mathrm{kyr}$ (Chapter 5). In central Australia, the earthquake mechanisms are consistent with north-south compression associated with Australia's ongoing collision with Indonesia/New Guinea.

The recurrence intervals for active faults in continental Australia are not well constrained, as is the case for intraplate regions worldwide, with 
estimates for large scarp-forming earthquakes $(\mathrm{M} \geq 6.0)$ between $10 \mathrm{ka}$ and $100 \mathrm{ka}$. Assessment of seismic hazard is difficult in a region with infrequent large events. Australia's most significant earthquake, in terms of human impacts, occurred in Newcastle (NSW) in 1989, with 13 fatalities and 160 people injured. This notwithstanding, the area had not been identified as particularly significant in the existing hazard maps of the day (ca 1979). This example illustrates the difficulty of hazard appraisal in regions where quiescence is the more prevailing status quo. Neotectonic fault movements attest to large earthquakes $(M<7.0)$ in the recent past in proximity to some of Australia's most populated centres in the SE Seismic Zone. Determining the likely recurrence rate for these earthquakes is therefore important for understanding Australia's seismic hazard (Chapter 11).

The eastern and northern margins of the Australian Plate are associated with active volcanism of the 'Pacific rim of fire'. Here, the subduction zones and their overlying environments form one of the most seismically active regions in the world, where around one-third of all earthquakes worldwide occur. The impact on Australia is felt from tsunamis generated by these earthquakes, which can reach Australia's coastline within two to four hours of the seismic event. The Joint Australian Tsunami Warning Centre (JATWC) is operated by Geoscience Australia and the Australian Bureau of Meteorology (BoM). The centre monitors, detects, verifies and warns the community of potential tsunami impacts on Australia's coastline and external territories. This system locates earthquakes using real-time data from 60 seismic stations in Australia and more than 130 international seismic stations, which, together with sonobuoys and tide gauges, calculates the tsunami risk to near-shore regions. The system is integrated with national emergency agencies to issue appropriate warnings within minutes of the initial earthquake. Modelling of hypothetical tsunami events, as well as measured ones, identifies Australia's northwest coast, particularly the Pilbara and Kimberley regions, and the more populated east coast, as having the highest tsunami risk (Chapter 6).

\section{Volcanic activity}

There are two active and emergent volcanoes in Australian territory, both lying within the Antarctic Plate on the oceanic Kerguelen Plateau (Figure 2.1). The approximately $2.2 \mathrm{M} \mathrm{km}^{2}$ Kerguelen Plateau is made of basalts with geochemical characteristics distinct from those of mid-ocean ridges. Mafic volcanism started around $110 \mathrm{Ma}$ and was associated with a hotspot. One active volcano is located on the Big Ben massif of Heard Island. Its most recent lava flow is $2 \mathrm{~km}$ long by $50-90 \mathrm{~m}$ wide (Box 1.4). The second volcano is located on the McDonald Islands, $44 \mathrm{~km}$ to the west of Heard Island - this was dormant for $75 \mathrm{kyr}$, then erupted in 1992 , with activity several times since.

Elsewhere on the Australian Plate, the main belt of volcanoes in the North Island of New Zealand formed as a result of the westward subduction of the Pacific Plate. Here, there are a number of active centres with widespread geothermal activity, with sometimes dangerous consequences for people. Strato-volcanoes include Ruapehu and Tarawera, both of which have claimed lives in the past

\section{Did know? \\ 2.1: Regional stress is important for hot-rock energy}

Australia's unusual horizontal compressiona stress state favours the exploitation of the nation's hot-rock geothermal resources (Chapter 10). Hot-rock geothermal systems use a fluid pumped through a closed loop to extract heat energy from surrounding rocks. The loop consists of a down-going well and an up-going well, connected via a fracture network, which is created by pumping fluid to very high pressures, forcing the intervening rock mass to fracture in ways governed partly by the local- to regional-stress state. Horizontal maximum stress encourages horizontal fracture systems, whereas vertical maximum stress encourages vertical networks. Horizontal fracture networks minimise fluid loss in the system, because the fluid, once it leaves the down-going well, can only travel laterally, promoting its intersection with the adjacent up-going well, and thereby recovering the energy. Containing fluid flow in vertical fracture systems is more difficult, as seen in the Rhine Graben in Germany, which is under an extensional (vertical maximum stress) to strike-slip stress state.

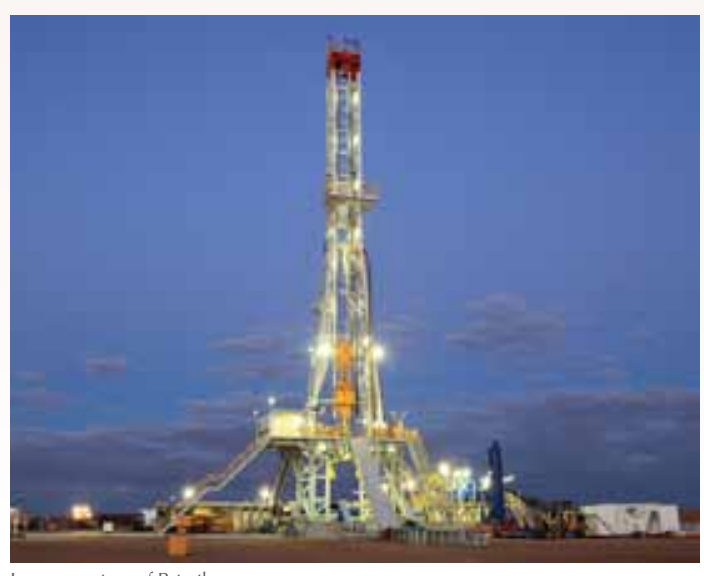




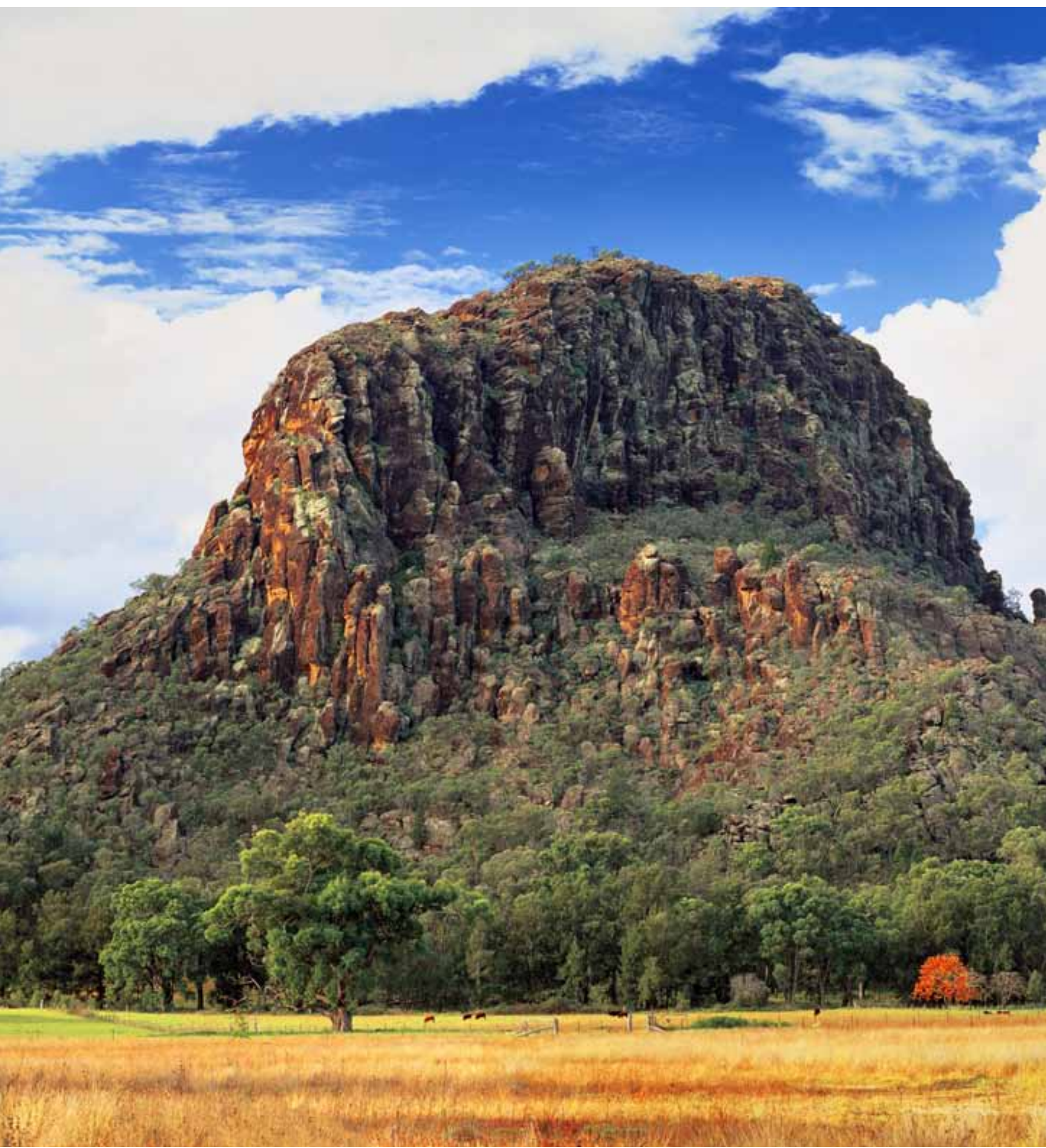

200 years through phreatic eruptions and lahars. Lake Taupo occupies the caldera of a super-volcano, which erupted at about $10 \mathrm{ka}$, leaving a shroud of tephra across the whole North Island.

The mid-ocean ridge between Australia and Antarctica is also an active volcanic region. This ridge has a significant physiographic influence on marine life, but also influences Earth's climate. The growth of oceanic phytoplankton sequesters around $20-25 \%$ of atmospheric $\mathrm{CO}_{2}$. Carbon storage in the Southern Ocean, however, is below full capacity because these waters lack the iron necessary for vigorous plant growth. Around $5-15 \%$, and in some areas up to $30 \%$, of the iron content of this ocean is derived from hydrothermal processes. The mid-ocean ridge volcanoes provide a relatively constant source of iron over millennial time-scales. These volcanoes also buffer short-term iron fluctuations derived from climate-driven sources such as wind-blown continental dust (Chapter 5) and the resuspended coastal sediments (Chapter 6).

In addition, there are many dormant volcanoes along the eastern margin of Australia (Figure 2.3). These form the Newer Volcanic Group, which is a chain of mostly mafic volcanic rocks that erupted along the Great Divide. These rocks stretch from Cape York Peninsula to southern Victoria

O Timor Rock volcanic plug in the Warrumbungle National Park, New South Wales.

o Getty Images [P Walton]

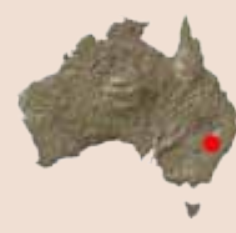


and South Australia, and occur as extensive lava fields (e.g. McBride in north Queensland) and as shield volcanoes (e.g. $12 \mathrm{Ma}$ Mt Canobolas in New South Wales). The soils derived from these volcanic rocks are some of the most fertile in Australia, especially where they occur in the higher rainfall regions (Figure 1.5). Diatremes associated with the Newer Volcanic Group also carried gemstones, such as diamonds, sapphires, rubies, garnets and zircons. To the east of the continent lies a series of subparallel seamount chains, with seamounts in the Tasman Sea, in the Lord Howe Rise, and Norfolk Island. They represent eroded volcanoes, such as the 15.6 Ma Gifford seamount (Figures 1.15 and 2.3), which mark the northward track of the Australian Plate over one or more mantle plumes.

The East Australian Plume System originated around $65 \mathrm{Ma}$, with the rifting of the Coral Sea. As the continent drifted north over the plume system, younger eruptions occurred increasingly to the south. The youngest dormant volcanoes occur in the intraplate region of southeast South Australia to western Victoria. They consist of nepheline hawaiites (a variety of basalt) dated at $4.6 \mathrm{ka}$, which were derived from partial melts of lower crust to upper mantle mafic rocks. Drill holes into the Gambier Basin produce commercial quantities of $\mathrm{CO}_{2}$ gas, once thought to be volcanic in origin, but now considered to

Figure 2.3: Distribution of Cenozoic volcanoes and lava fields in eastern Australia. Note the southward decrease in age of shield volcanoes and seamounts in three parallel tracks. These volcanoes were formed as the Australian Plate moved north-northeast over a series of mantle plumes. (Source: after Johnson, 2009)

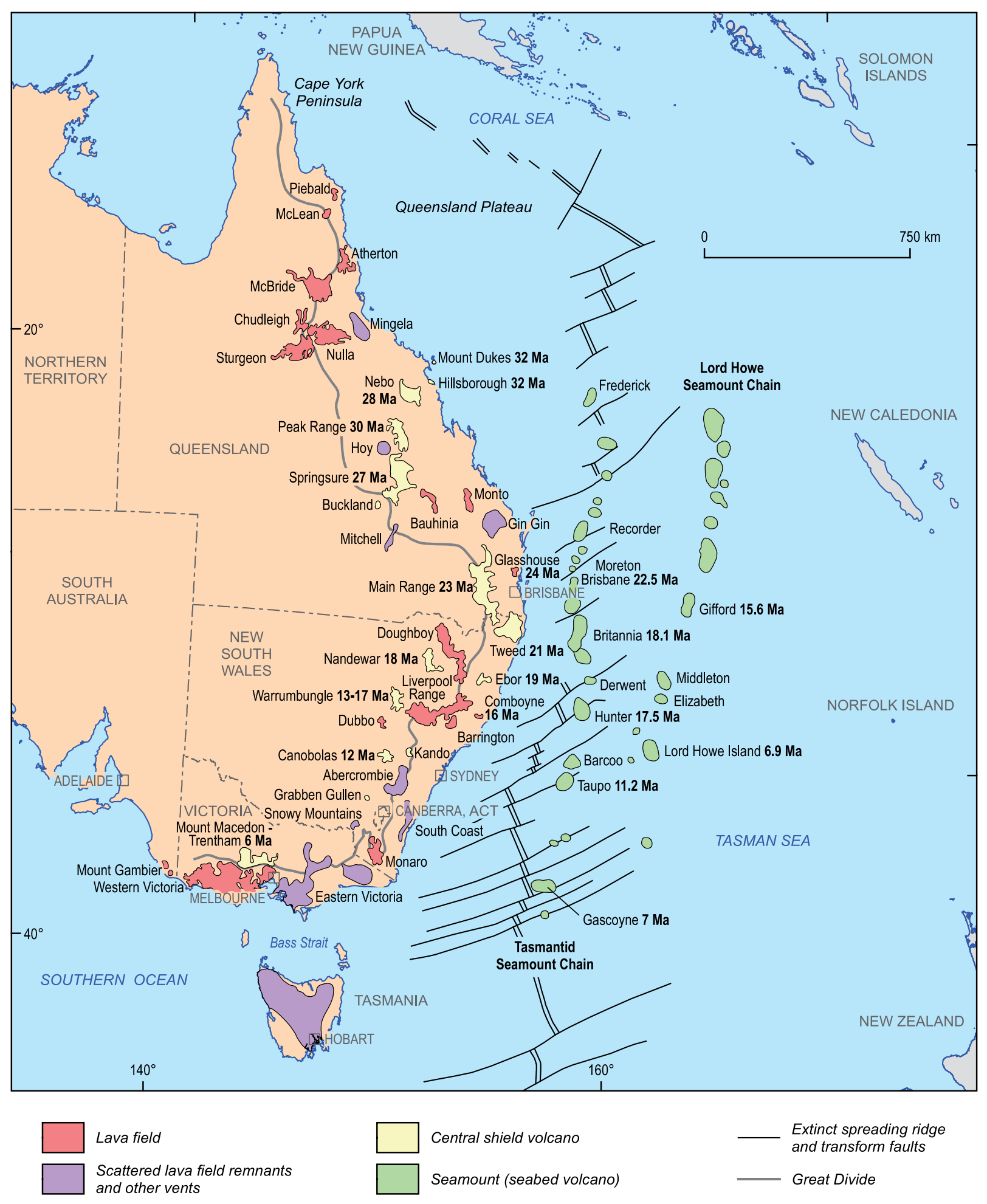


to discover and chart 'unknown southlands'. By 1623, Carstensz had named parts of Cape York Peninsula. From the 1600s to the 1800 s, various European explorers, including the Dutch, French and British, had charted Australia's coastline and added to the map. Louis de Freycinet and Matthew Flinders published the first complete maps of Australia in 1811 and 1814, but James Cook had noted geological features such as the Glasshouse Mountains on the southeast Queensland coast in 1770. European settlement, migration and inland exploration provided further geographical details, and geological exploration began.

Unlike all the other continents on Earth, Australia is governed as a single sovereign nation - a political factor that has facilitated the systematic mapping of the continent. With each technological advance, Australia has been mapped in ever-increasing sophistication and detail. Australia is well served by high-quality geological and geophysical maps. The data form a vital input to Australia's pre-competitive data inventory, with the Australian Government, together with state and territory geological surveys, promoting the nation as an attractive destination for mineral and energy explorers. Many others have since copied this lead, but no other country has such a comprehensive coverage, which is freely available for download (www.ga.gov.au/gadds). The maps and results illustrated in the following section include representations of continental-scale topography and bathymetry, remote sensing, soils, gamma-ray spectrometry, potential fields (gravity and magnetics) and lithospheric mapping. Further presentations of these results are in Appendix 2. Definitions of the spatial and temporal terms are given in Table 2.1.

Table 2.1: Definition of the spatial and temporal terms used

\begin{tabular}{|c|c|}
\hline Term & Definition \\
\hline Supercontinent & A large continent formed by the amalgamation of most or all of Earth's continental landmasses. \\
\hline Supercraton & A large, ancestral (largely Archean) landmass consisting of two or more cratons. \\
\hline Continent & One of Earth's major landmasses (or former major landmasses). \\
\hline Element & $\begin{array}{l}\text { Part of a continent that has some shared broad-scale geological history; often an interpreted proto-continent } \\
\text { or collection of such continental fragments (including cratons) that now forms part of an extant continent. }\end{array}$ \\
\hline Craton & A part of Earth's continental crust that has attained stability and has been little deformed for a prolonged period. \\
\hline Province & $\begin{array}{l}\text { A large geological region showing similarities in its geological history to adjacent provinces, but with a different } \\
\text { geological history. }\end{array}$ \\
\hline Superterrane & A collection of two or more terranes. \\
\hline Terrane & A region with essentially similar geology and geological history. \\
\hline Domain & A usually fault-bounded region of similar geology. \\
\hline Superbasin & A group of temporally and genetically related basins. \\
\hline Basin & A low area at Earth's surface of tectonic origin in which sediments have accumulated. \\
\hline Inlier & An exposure of basement rocks completely surrounded by younger basinal rocks. \\
\hline Seismic province & $\begin{array}{l}\text { A discrete volume of middle to lower crust, which cannot be traced to the surface, whose seismic reflectivity is } \\
\text { different from that of adjoining provinces, either laterally or vertically. }\end{array}$ \\
\hline Orogen & $\begin{array}{l}\text { An often linear or arcuate region that has been subjected to one or more common episodes of deformation and } \\
\text { metamorphism (orogenies). }\end{array}$ \\
\hline Orogeny & Geological event or genetically and temporally closely related events involving rock deformation. \\
\hline Movement & $\begin{array}{l}\text { Geological event or genetically and temporally closely related events involving rock deformation. Used } \\
\text { where previously defined orogenies (e.g. Alice Springs) are found to include unrelated orogenic events. }\end{array}$ \\
\hline Event & $\begin{array}{l}\text { A temporally and, commonly, spatially restricted occurrence of a geological process or related geological } \\
\text { processes. This can include magmatism (igneous event), deformation (deformational event, orogeny or } \\
\text { movement) or mineralisation (mineralisation event). }\end{array}$ \\
\hline
\end{tabular}

\section{Surface relief}

Flying from Europe or Asia over the Australian continent to the east coast, it is easy to see why the expression 'old, flat and red' to describe Australia is so apt (Chapter 5). The large cratonic blocks of Precambrian rocks in the western two-thirds of Australia form the core of the continent. The ochre-red colours of the 'outback' are a testament to the aridity, driven by Australia's plate position with respect to the monsoonal belts in the north, and the westerly winds in the Southern Ocean. Australia is the lowest and flattest continent, and has been the most slowly eroded and deeply weathered on Earth (Figure 1.5).

The average elevation of the continent is about $330 \mathrm{~m}$, with a maximum local topographic relief typically less than $1500 \mathrm{~m}$. Other than the upland areas, the bedrock erosion rates are typically less 


\section{IMPACT CRATERS (воx 2.1)}

The collision of extraterrestrial bodies with Australia is inevitable, given the great age of the geology and landscape. Australia has a total of 35 confirmed impact sites from the Late Precambrian onwards, 22 unconfirmed impacts and 10 sites with identified impact ejecta. The size of the impacts ranges from a few hundred metres to more than $100 \mathrm{~km}$ in diameter.

Australites are the glassy tektites (ejecta) found across southern Australia. Examples from Victoria are around $800 \mathrm{ka}$. They were reputedly used as cutting tools or sacred objects by Aboriginal people. Other impacts are concealed beneath the ocean or in sedimentary basins-these are inferred from their geophysical signatures. For example, a large feature beneath the Cooper Basin in South Australia is interpreted as a major impact that might have been partly responsible for generating the heat anomaly. The area coincides with an elliptical-shaped magnetic high, which is around $100 \mathrm{~km}$ in diameter. Shock-textured quartz from Carboniferous granites recovered from deep drillholes is consistent with an impact.

Other impacts, such as the impressive 300 ka Wolf Creek crater, are exposed as eroded circular-shaped remnants in the landscape. The smaller Veevers crater in Western Australia is thought to be $<20 \mathrm{ka}$, and this impact may well have been felt by nearby Aboriginal people. In the Northern Territory, rocks fractured into a regular 'shatter cone' pattern by intense, sudden pressure have been found at the $5 \mathrm{~km}$ diameter and $150 \mathrm{~m}$ high Gosses Bluff crater west of Alice Springs in central Australia. This impact occurred ca $142.5 \mathrm{Ma}$. The site is sacred to the local Western Arrernte Aboriginal people. They name it Tnorala and relate its formation to a cosmic impact during the Dreamtime:

A group of celestial women were dancing as stars in the Milky Way. One of the women became tired and placed her baby in a wooden basket. The women continued to dance and the basket with baby fell to the Earth, the impact forced the ground upward, forming the circular mountain range. The baby's parents, the evening and morning star (Venus), continue to search for their baby. (Thornton, 2007)

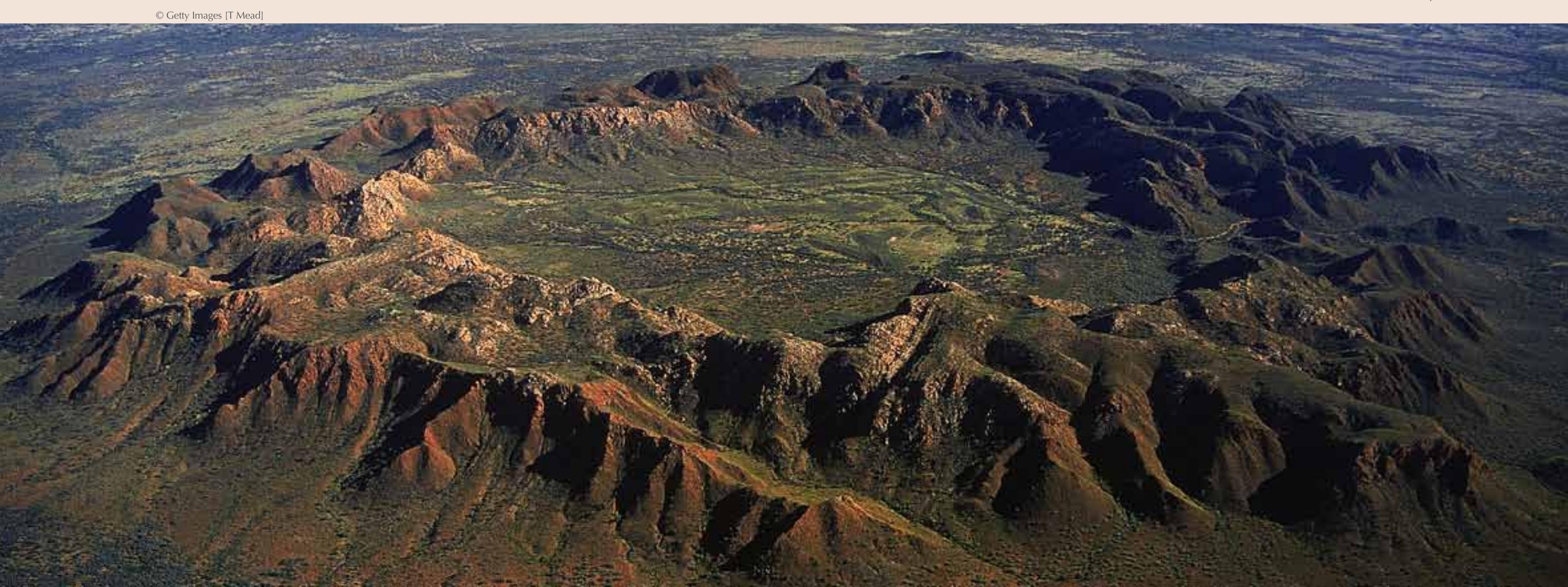




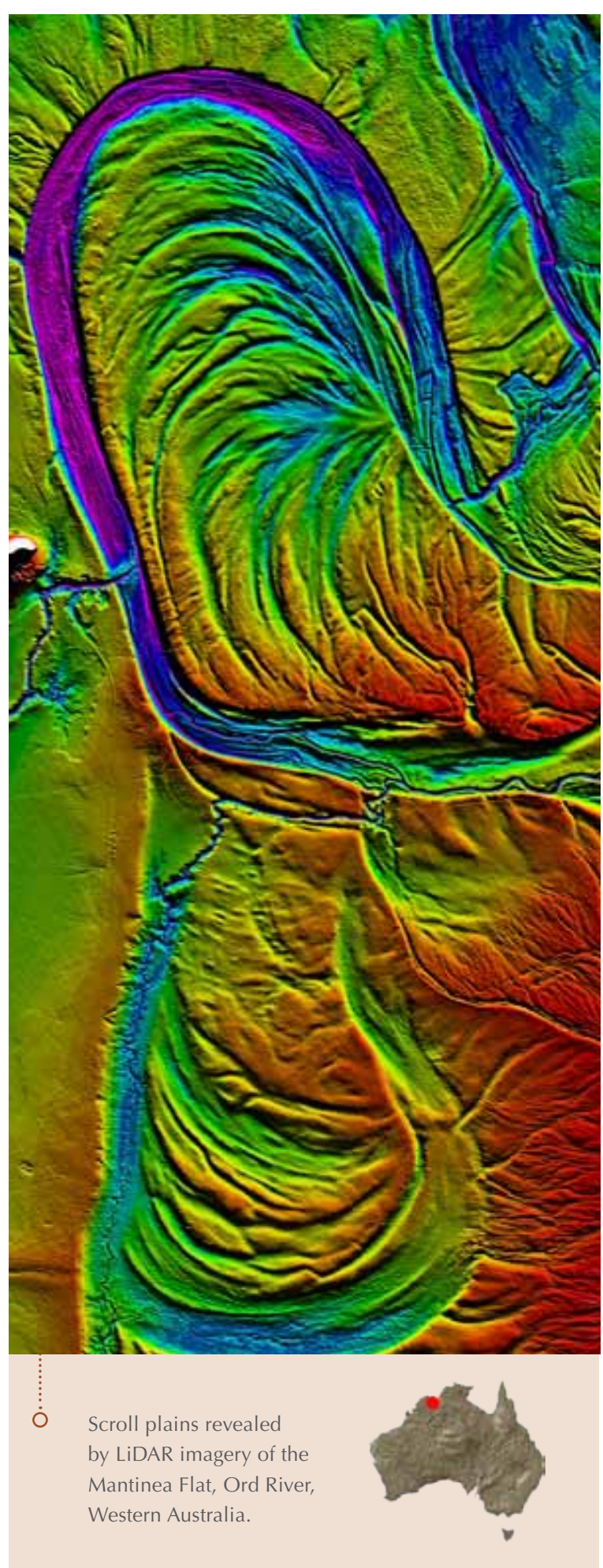

The wide continental shelf between the coast of northern Australia and Indonesia, Timor and New Guinea is a relatively fertile fishing ground and also host to great hydrocarbon wealth. The extended continental North West Shelf contains large natural gas resources, and is marked by complex embayments and salients left over from the breakup of Gondwana (Chapter 4). The continental slope on all margins is deeply incised, with steep-sided canyons up to $2 \mathrm{~km}$ deep. Australian margins, like those in Antarctica, are unusual because deep river-associated canyons do not dissect their continental shelves. More than $80 \%$ of Australia's canyons are blind, probably because of Australia's low rainfall, low relief and lack of continentally derived sediment transport to the oceans (Chapter 6). Some of the larger canyons influence ocean currents and attendant fertility - the head of the Perth Canyon off southwest Western Australia, for example, is a haven for whales.

\section{Topography and bathymetry}

The representation of surface topography is now carried out with a digital elevation model (DEM) based on the use of point elevation data; commonly, a regular grid of elevation points is employed. Such grids can be directly observed, but generally they are computed from other elevation information such as contours or irregularly spaced spot heights. High-resolution digital terrain maps can be generated from the National Aeronautics and Space Agency's (NASA, in the United States) Shuttle Radar Topography Mission (SRTM). NASA has released the SRTM dataset for Australia, New Zealand and many South Pacific islands. Research agencies in Australia have combined to increase the resolution to a one-second grid, or around a $30 \mathrm{~m}$ pixel size. The new image has many benefits; for example, water catchment boundaries can be better mapped, and terrain data can be used for modelling surface/groundwater interactions, as well as landscape evolution. Underlying geological features are also revealed in the elevation data (Figure 1.5).

For more local high-resolution elevation information, the LiDAR (light detection and ranging) technique can be employed. LiDAR maps are generally acquired over smaller areas than the SRTM technique. These high-resolution digital elevation maps have led to significant advances in geomorphology, where very subtle topographic features are readily resolvable. For example, near the mouth of the Murray River in eastern South Australia, ancient river terraces with scrolls and channel banks are defined in great detail (Chapter 5). Combining aircraft-based LiDAR and satellite geodesy provides another tool for detecting faults and measuring uplift across a region.

Most of the Australian Plate is under the sea, and bathymetric images reveal a highly complex surface, reflecting the formative geological processes. Geoscience Australia has been collecting bathymetry data routinely from seismic and sampling surveys around the Australian margin since 1963. More recently, Geoscience Australia has taken on the role of national bathymetry custodian for all holdings within the Australian marine jurisdiction. These data consist of ship-track and swath bathymetries, digitised soundings from hydrographic charts and laser airborne depth-sounder data from more than 1400 surveys. The data were acquired by 
Geoscience Australia, as well as by other scientific institutions, oil exploration companies and academic organisations. In addition, some data have been sourced from the National Geophysical Data Centre (United States), to which various institutions have contributed (Figures 1.5 and 4.9).

\section{Satellite remote sensing}

Satellite remote sensing has proved very valuable in characterising features of the Australian continent.

There are two basic types of sensor systems mounted on orbiting satellites:

- active systems, such as Synthetic Aperture Radar (SAR) that generate their own electromagnetic radiation, measuring a return signal response

- passive systems, such as Landsat, that use an array of detectors to record electromagnetic radiation, which is reflected and/or emitted from Earth's surface.

The data are transmitted to ground stations, such as at Alice Springs (NT). These data, when processed, can be used to create images of Earth's surface. Satellite images differ from high-altitude aerial photographs in two main ways:

- firstly, the acquisition of a broader bandwidth of the electromagnetic spectrum, such as infra-red, enables improved identification and assessment of surface features

- secondly, the regular updates from each satellite pass enable time-based analysis of the surface. Being a digital product, satellite remote sensing imagery can be easily integrated with other spatial imagery.
The Landsat 7 Picture Mosaic of Australia was produced by the Australian Greenhouse Office as part of its National Carbon Accounting System (Figure 2.4). The mosaic consists of 369 individual Landsat satellite scenes, acquired between July 1999 and September 2000, and utilises the 2, 4, 7 spectral bands (as blue, green, red colours). The mosaic clearly shows the arid interior, in brown and yellow colours, contrasting with the more watered coastal zone of eastern Australia and southwest Western Australia, in shades of green. The major ephemeral lake systems in central Australia mark the lowest point in the landscape, and these capture occasional surface-water runoff from the Channel Country to the northeast (Figure 1.4). The productive 'wheat belt' in southwest Western Australia is clearly visible from space, demonstrating the impact that people can have on the landscape (Figure 2.4). To the east and north, the desert and semi-desert of the interior has saline lakes, remnants of past freshwater river and lake systems that drained into the Southern Ocean. The classic Archean granite-cored domes are well exposed near the Pilbara coast. These domal map patterns may have formed under an early-Earth tectonic system, one that was different from modern plate tectonics (see later).

Land cover is defined as the observed biophysical cover on Earth's surface, including trees, shrubs, grasses, soils, exposed rocks and waterbodies, as well as anthropogenic elements such as plantations, crops and built environments. Changes occur to land cover from factors such as seasonal weather, severe weather events, fires and human activities, including mining, agriculture and urbanisation.

\section{Did knouw?}

\subsection{Ocean drilling}

The Ocean Drilling Programme (ODP) was an international partnership involving 22 countries and hundreds of researchers to understand Earth's evolution. Projects were focused on all aspects of the geosciences. Australia participated from 1988 until ODP finished in 2003. Up to 2001, 17 survey legs were completed, many in Australia's jurisdiction. Leg summaries and their locations in Australian waters are presented in Appendix 2.

The Integrated ODP is the current successor organisation (www.oceandrilling.org). Australia, in partnership with New Zealand, joined in 2005, with funding guaranteed until 2012. Expedition 325, completed in mid-2010, drilled three key localities on the outer edge of the Great Barrier Reef in water depths of $42 \mathrm{~m}$ to $167 \mathrm{~m}$. The area was chosen to study sea-level rise and ocean chemistry for the past $20 \mathrm{kyr}$, because it is located in a tectonically stable region distant from major ice sheets.

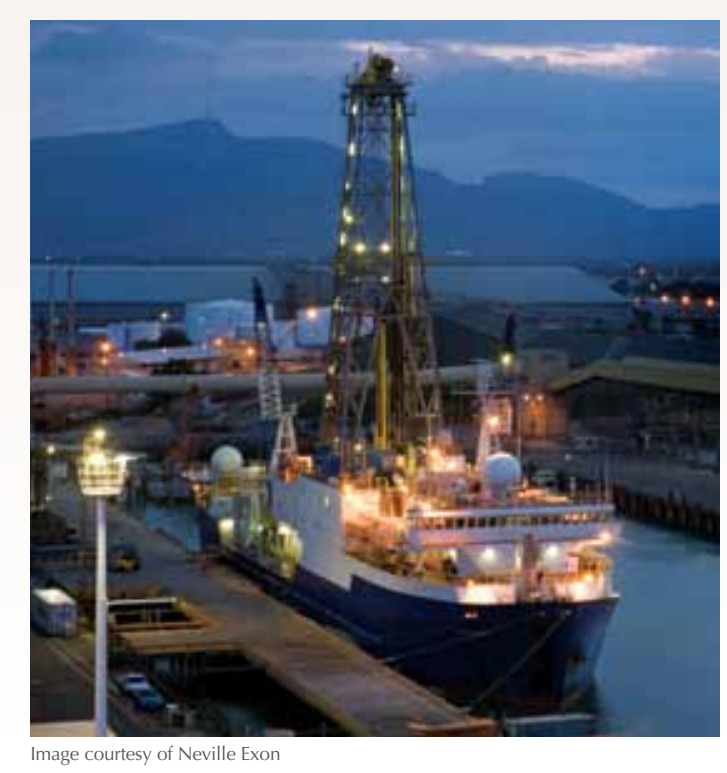




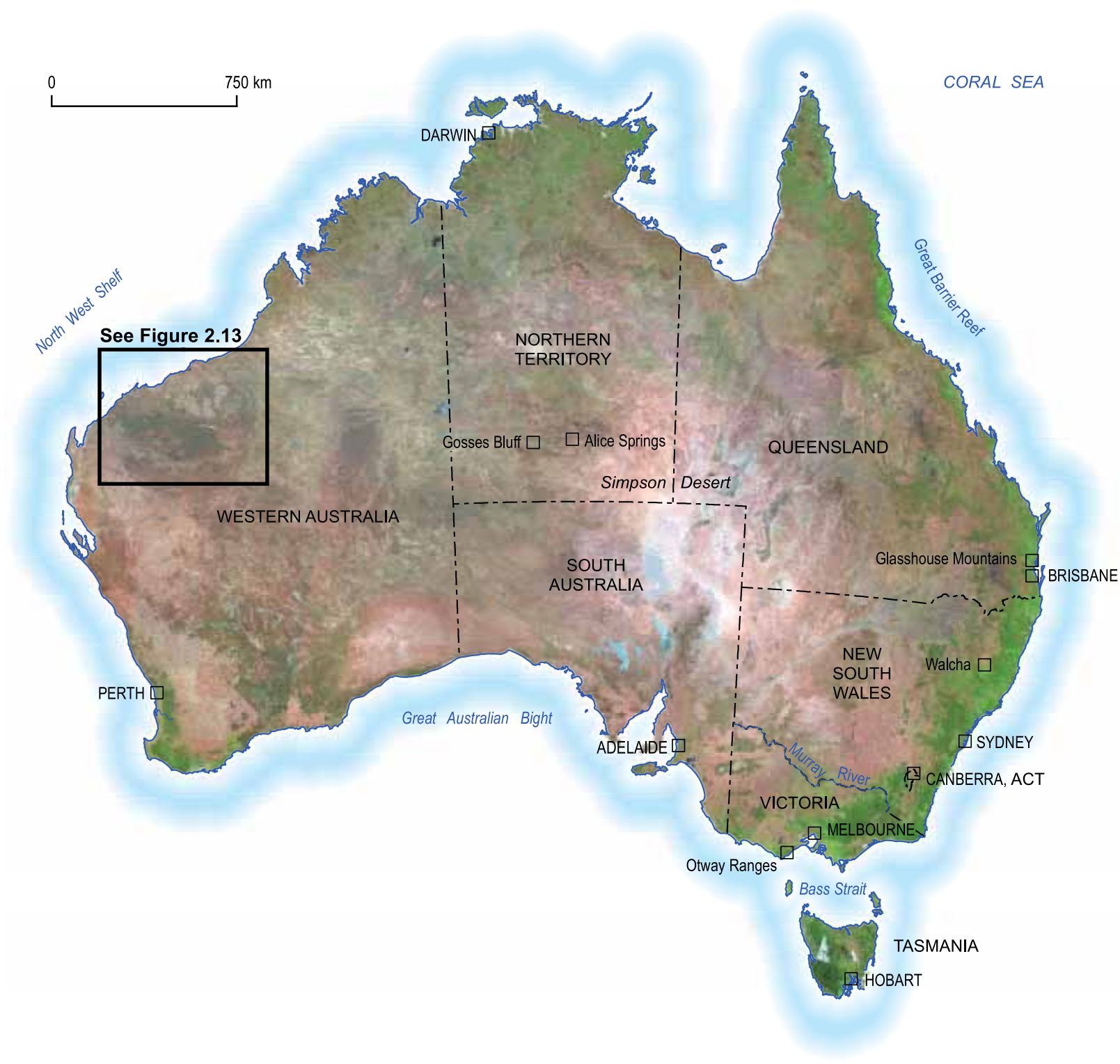

Figure 2.4: True colour mosaic (bands 2, 4 and 7) of Landsat satellite imagery over Australia, highlighting the differences in vegetation as a reflection of rainfall (Chapter 1). The boxed area in the Pilbara is enlarged in Figure 2.13a. (Source: Australian Greenhouse Office, 2005)
Satellites are able to map land cover and how it changes through time. Australia's land cover map was made from time-series satellite data using the Moderate Resolution Imaging Spectroradiometer (MODIS) system from NASA. The time series includes 186 snapshots of vegetation greenness for each $250 \mathrm{~m}$ by $250 \mathrm{~m}$ area across the continent over the period April 2000 to April 2008. The land cover map provides a baseline for reporting on change and trends in vegetation cover and extent. Information about land cover dynamics is essential to understanding and addressing challenges such as drought, salinity, water availability and ecosystem health.

\section{Soils}

Australian soils, like the landscape, are the products of the long-term evolution of the climate, life, topography and geological parent materials (Chapter 5). Australian soils tend to be old, salty and clayey, except in the west of the continent, where they tend to be sandy, acidic, and nutritionally and organically impoverished, and pose structural challenges to building construction. Compared with those in the Northern Hemisphere, Australian soils generally have less organic matter and poor structure, and tend to be clay-rich near the surface. These clayey characteristics tend to restrict water drainage, impede root growth and, due to their 'shrink and swell' nature, impact engineering and farming. The clays adsorb heavy metals and even pesticides, concentrating them in the environment until chemical changes release them. 
The agricultural landscapes of Australia support a great range of soils of varying thickness. Most are ancient, strongly weathered and infertile. Others are younger and more fertile. This variety, along with the natural limitations of many soils and their interactions with climate, has made it difficult to develop sustainable agricultural systems. Limitations to productivity have also been induced through human impacts on soils. While some forms of degradation such as nutrient deficiencies can be corrected, others, such as soil erosion, are difficult to remedy. Remediation is impeded because the rate of soil formation is slow in most areas.

Large areas of Australian soils are affected by salt and have various nutrient and physical limitations for plant growth and therefore agriculture. Their iron-rich nature means that such soils are susceptible to phosphorus adsorption, impeding the uptake of added fertiliser to crops. Soil fertility and usability, together with net water budgets, have had a profound influence on determining the distribution of the Australian population (Figure 1.3). These factors highlight the contrast between Australia's agricultural development and that of Europe and North America.

\section{Gamma-ray spectrometry}

All rocks and soil contain some of the major radioactive elements uranium $(\mathrm{U})$, thorium $(\mathrm{Th})$ and potassium (K). The decay of these elements gives rise to a natural gamma-ray flux, which can be measured with a suitably equipped aircraft. The energy distribution of the gamma rays is specific to the decay chain for the particular elements, and

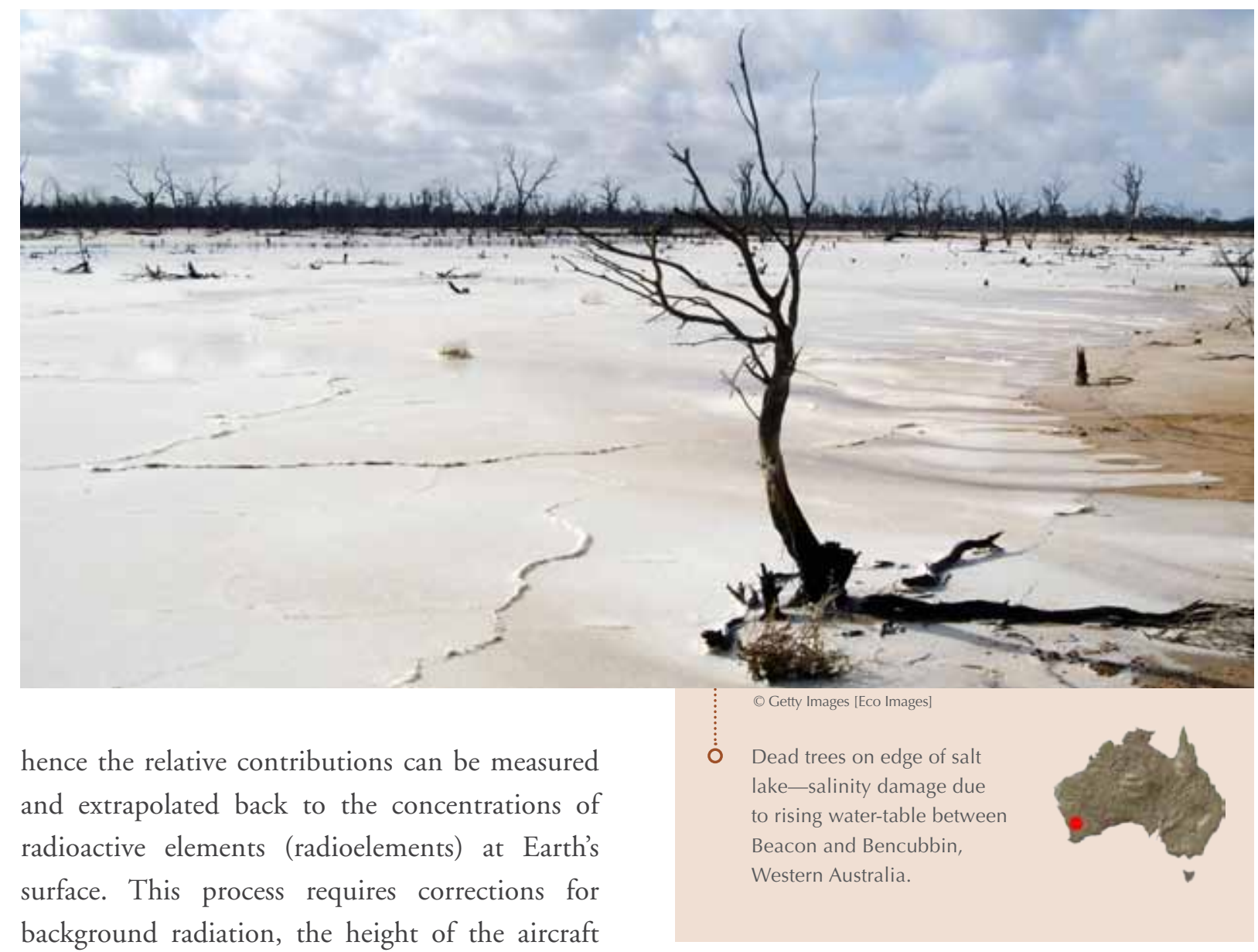
above the ground, and the response and sensitivity of the detector.

The normal mode of display of the results is via a three-colour image, with the $\mathrm{K}$ concentration on the red channel, Th on the green channel and $\mathrm{U}$ on the blue channel. The ternary image is essentially a chemical map of the near-surface distribution of these three elements and is strongly correlated with surface geology and the rate of erosion or deposition in the landscape. Areas that are low in all three radioelements appear as dark hues (ultramafics, quartzites and sandstones), and areas that are high in all three elements appear as white 


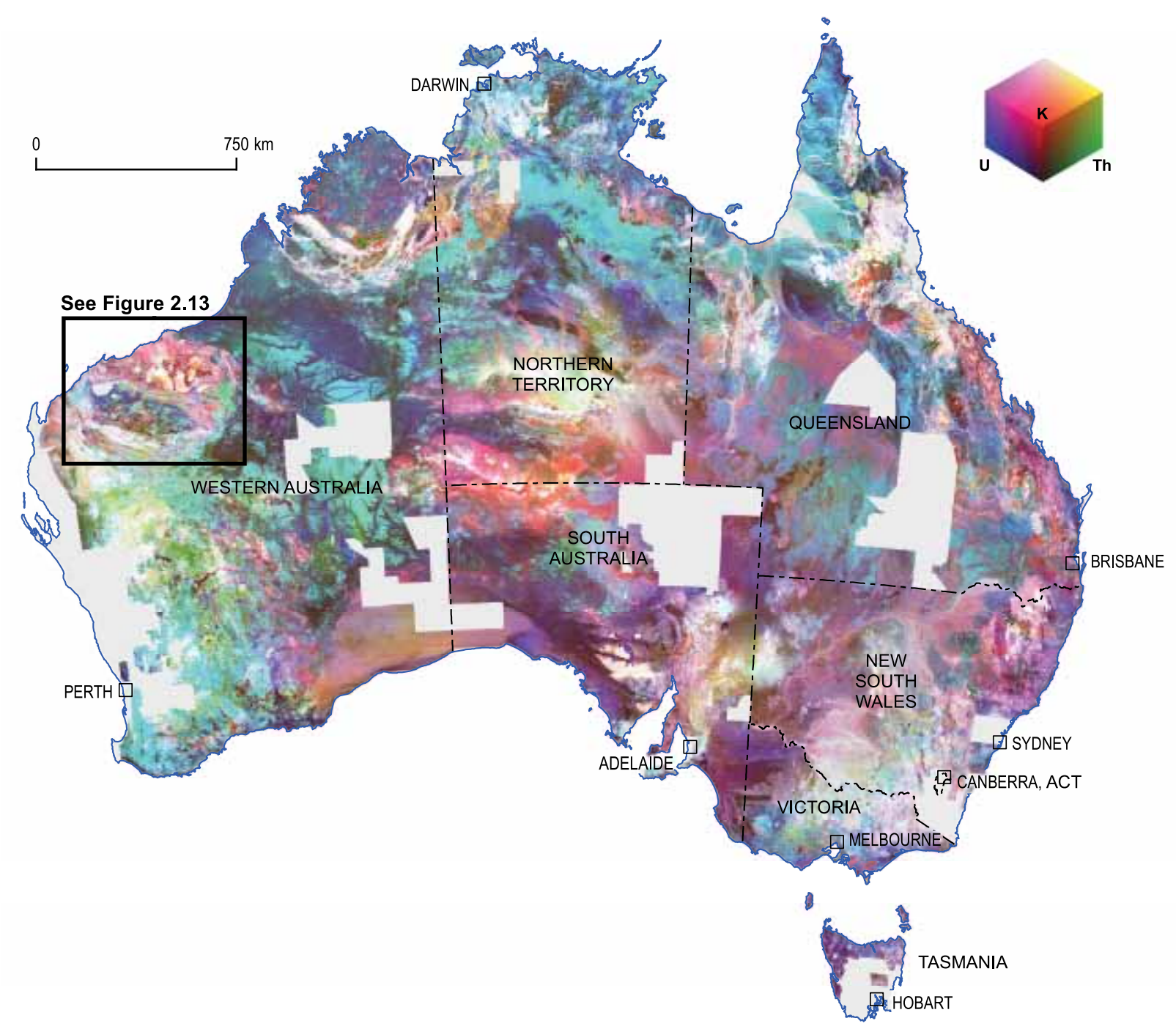

Figure 2.5: Gamma-ray or spectrometric map of Australia synthesised by combining results from many individual airborne surveys (after Geoscience Australia). The gamma-ray map shows the distribution of potassium (red), thorium (green) and uranium (blue) in the top $30 \mathrm{~cm}$ of the surface. Dark coloured and black regions are low in total counts of the radioelements-these are commonly quartz-rich sand-covered areas. The white regions are high in total radioelements and are commonly associated with areas of active erosion, especially of felsic (granitic) rocks. The pale-grey areas are data acquisition gaps. The boxed area in the Pilbara is enlarged in Figure 2.13b. hues (felsic volcanics and granites). Weathering, erosional and depositional processes play a large part in forming the radiometric response. Many of the green and green-blue areas, representing high Th but low $\mathrm{K}$, are highly weathered surfaces rich in iron.

Most gamma-ray surveys are carried out over a limited area, and careful processing is required to link together the results from separate surveys. A major effort has been made in recent years to link the results at the continental scale, and the spectacular outcome is shown in Figure 2.5. This map is the largest single gamma-ray dataset collected at this resolution anywhere on Earth.

Localised high concentrations of the radioelements are clearly visible in the granites of the Pilbara and the eastern Yilgarn cratons (WA), in central Australia and in the New England region of northern New South Wales. Other concentrations occur in the Flinders Ranges (SA), which is also noted as a zone with enhanced geothermal heat flux, most likely associated with a high concentration of these heat-producing elements in the crust (Chapter 10).

Many geological features and boundaries are well delineated in the ternary image. For example, the Mesozoic shoreline on the northern margin of the Nullarbor Plain (WA) is clearly distinguished from the Th-rich Yilgarn Craton. The actively eroding fold-belts surrounding the Kimberley region are prominent against the more sombre tones of the Kimberley itself. There is also a very clear image of the remote Canning Basin in northwestern Western Australia, much of it forming the Great 
Sandy Desert between the Kimberley and the Pilbara regions. The mineral provinces around Mt Isa and Broken Hill have a distinctive signature. The granites along the eastern margin are bright red and white colours and shades, consistent with their high concentrations of radioelements.

In Australia, the acquisition of airborne gamma-ray data has become routine when magnetic data are being acquired. The data are used specifically for geological and landscape mapping and in assessment of alteration associated with mineralisationespecially U. Linking the measurements from rock-sample geochemistry and the gamma-ray data has shown that Australia is 'missing' a huge amount of $U$ (Chapter 10). The data have become one of the key means of prediction to map specific soil properties (e.g. clay content). The results have been used for land-use planning, such as mapping soils, vegetation (even viticulture) and animal ecology.

\section{Surface geochemistry}

Australia has a near complete coverage of multi-element surface geochemistry. Because of the varied landscape and climate of Australia (Chapter 5), a specific sampling methodology was developed. The coverage consists of 1315 samples collected near the outlet of 1186 catchments, covering $81 \%(6.2 \mathrm{M} \mathrm{km}$ ) of Australia. All samples were analysed for up to 68 elements by as many as three complementary methods. The average sampling density was around 1 site per $5200 \mathrm{~km}^{2}$. A geochemical atlas and dataset are freely available from Geoscience Australia’s website. The geochemical maps show continental-scale patterns (Figure 2.6). They also provide the geochemical

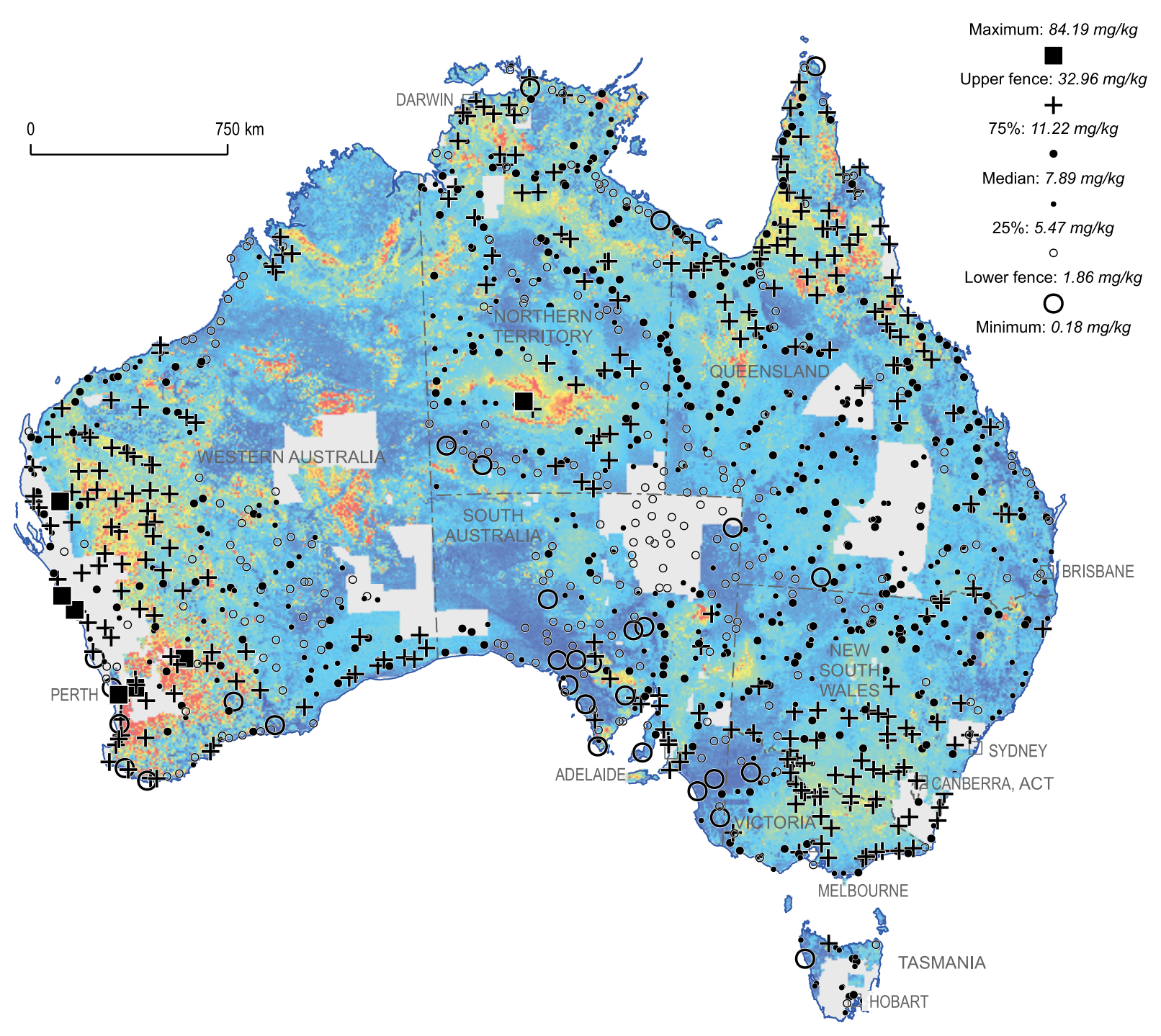

Figure 2.6: Map of soil Th concentration from the top $10 \mathrm{~cm}$ of the surface from 1190 sites distributed across Australia, overlain on an airborne radiometric Th channel image. Although the data density is low, the map provides the first consistent picture across most of Australia of the distribution of the elements analysed. (Source: de Caritat \& Cooper, 2011) 


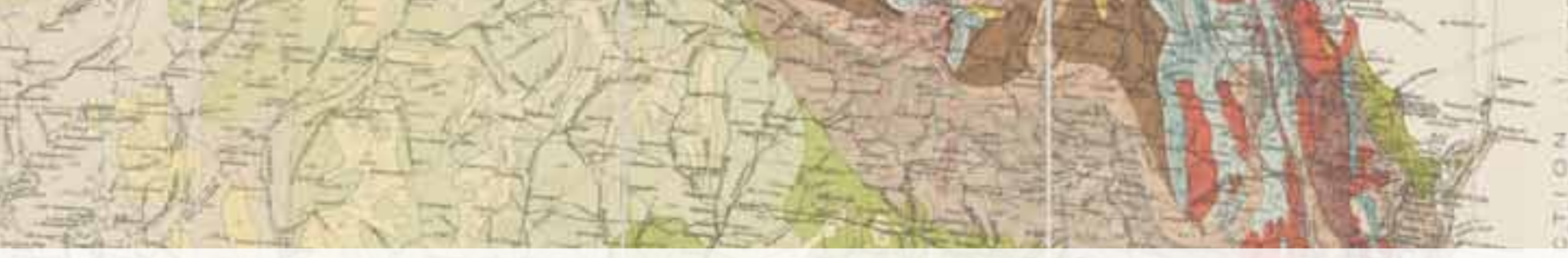

\section{PIONEERS OF GEOLOGICAL MAPPING}

\section{IN AUSTRALIA (воx 2.2)}

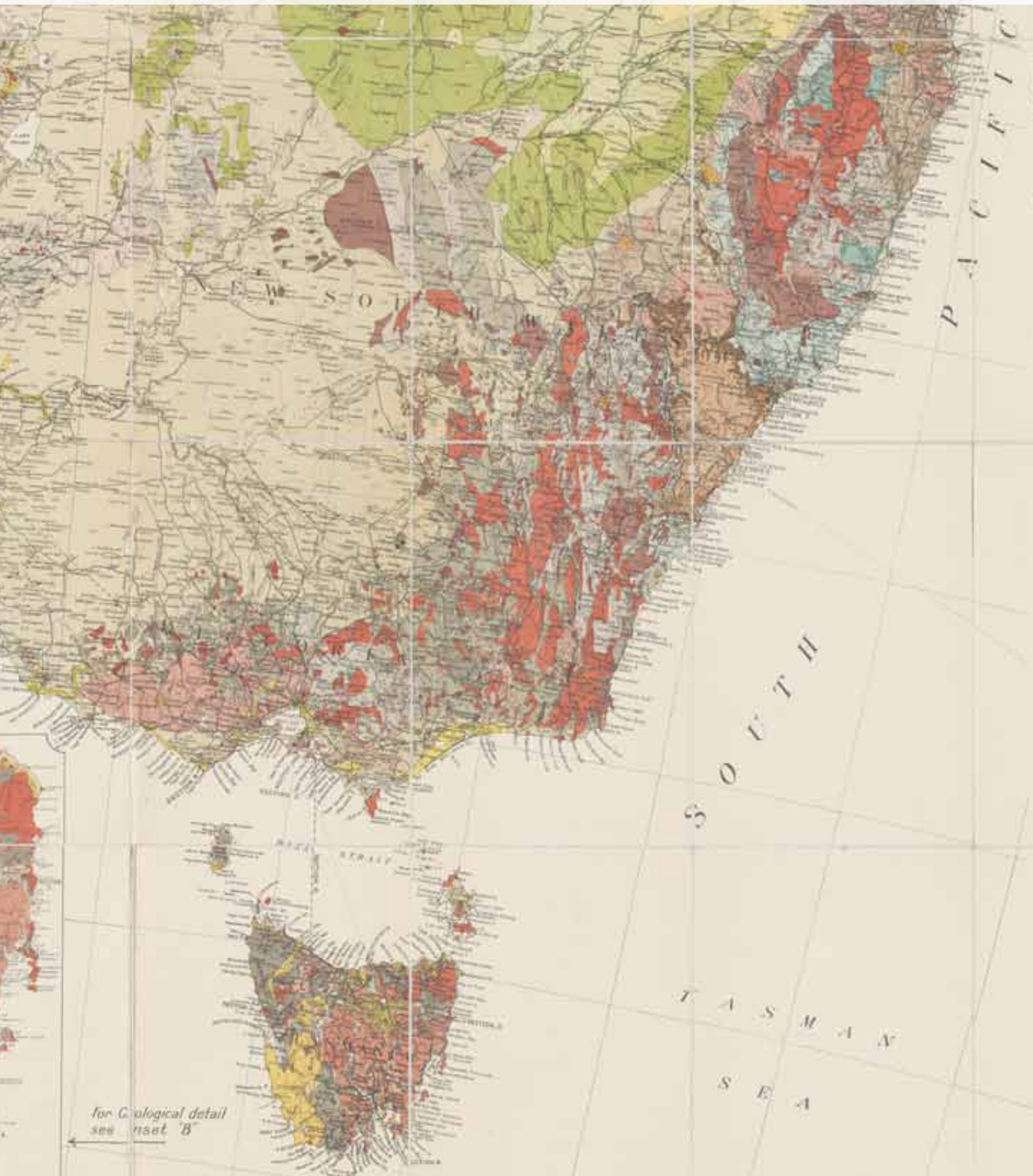

Mapping after the 1830s, by explorers such as J Lhotsky, PE Strzelecki, T Mitchell, JD Dana and L Leichhardt, noted areas likely to contain coal, limestone or metalliferous deposits, as well as fossils to date rocks, potential dam sites and the variability of soils. These tantalising glimpses of potential led to the colonial governments establishing geological surveys. In terms of national geological maps, the Strzelecki 1845 map of New South Wales and southeast Australia and the First sketch of a geological map of Australia including Tasmania, published in 1875 by R Brough Smyth, were the first geological maps of the continent. The Smyth map was issued at a scale of 110 miles to an inch in two sheets, which are in the National Library of Australia.

In 1887, the map Continental Australia: from the most recent information and materials supplied by the survey departments of the several colonies geologically colored [sic] by Arthur Everett was published. The map was sourced from state geological maps, with the base map supplied by the Victorian Lands Department. It was one of the largest geological maps published in Australia at that time, and, priced at $£ 3.10 .0$ (more than $\$ 500$ in 2012 terms), was the most expensive map issued by the department.

The 1932 Geological map of the Commonwealth of Australia and a volume of Explanatory notes, the culmination of several decades of work by TW Edgeworth David, were one of the most significant early contributions to Australian geology. In the late 1940's, the Bureau of Mineral Resources (now Geoscience Australia) and state geological surveys began 1:250 000 scale mapping of the map sheets of Australia; there were more than 600 of these maps. This marked 
the beginnings of a comprehensive understanding of Australia's geology. This mapping was built on the observations and recording of all those earlier generations of geoscientists who covered vast distances under difficult physical conditions and limited basic information.

The unknown frontier today is depth. The challenge for the various mapping agencies is to map the 3D geology of Australia. Advances in geophysics are integral to this aim (Chapter 11).

Some of the early pioneers in geological mapping are noted below.

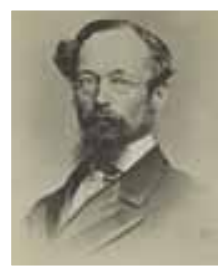

Image courtesy of State
Library of Victoria. Library of Victoria.
Image no. H83.86/1

\section{Alfred Richard Cecil Selwyn}

(1824-1902)

Appointed Geological Surveyor of Victoria in 1851, Selwyn mapped large tracts of the colony, helping to establish the stratigraphy. Under his direction (1853-69), the Geological Survey of Victoria issued more than 60 geological maps and numerous reports. At the time, they were compared favourably with the best in the world. In 1865, he published a geological map of Victoria in eight sheets.

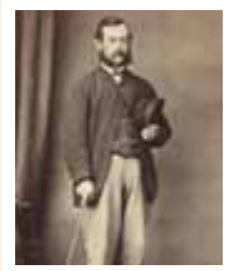

Charles Gould (1834-93)

Gould was Tasmania's first Geological Surveyor (1859-69). His primary task was to discover gold. Gould's surveys covered much of the colony and added greatly to the geographical knowledge of western Tasmania. Image courtesy of LIN

He established the Ordovician to Lower Devonian stratigraphy, correctly deduced the succession of Permian and Triassic coals and Jurassic dolerite, and suggested mining for coal under dolerite.

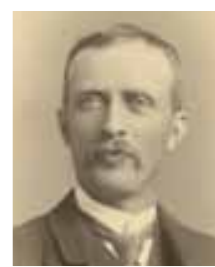

Image courtesy of State Library of South Australia

Henry Yorke Lyell Brown

(1843-1928)

Brown arrived in Australia in 1865 and worked in Victoria, Western Australia and New South Wales. In 1882, he was appointed Government Geologist of South Australia. His major achievement was the publication of the geological map of the colony in 1899 (including the Northern Territory). On his death, it was said that 'he knew every mineral belt from Darwin to Mt Gambier'.

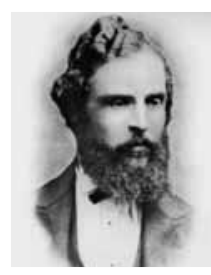

\section{Robert Logan Jack}

(1845-1921)

As Geological Surveyor for northern Queensland (1876), Jack contributed greatly to the geological knowledge of Queensland. His work covered gold, tin, gemstones and coal. Jack's work was of outstanding

mage courtesy of lot of Queensland, Neg: 192.3

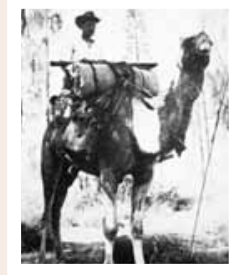

Henry William Beamish Talbot (1874-1957)

Talbot joined the gold rush at Kalgoorlie (1893). He worked for the Geological Survey of Western Australia (1899-1920), typically spending 7-8 months a year exploring remote areas of the state. He explored for oil in the Canning Basin (1921-30), and worked for Western Mining Corporation (1933-47). Government Geologist AG Maitland said 'Few men have contributed more to our knowledge of the inaccessible and arid regions of the state'.

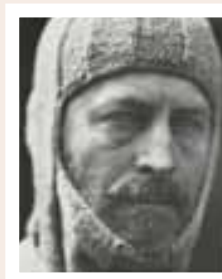

Sir Douglas Mawson

\section{(1882-1958)}

Mawson's major contributions to Australian geology were in the area of Precambrian stratigraphy and glaciation, particularly the rocks of the
Flinders Ranges. Under his leadership, the University of Adelaide became renowned in accurate and detailed observation. Perhaps his greatest contribution was his work on artesian water and the construction of the first government bore in the Great Artesian Basin (1887).

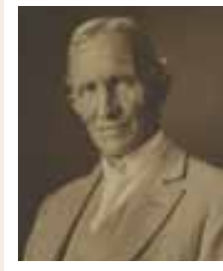

mage courtesy of John Oxley Library, State Library
of Queensland, Neg: 19233
Sir Tannatt William Edgeworth David (1858-1934)

David is arguably Australia's most widely accomplished geologist. His mapping assisted the tin and coal industries in New England and Hunter regions. He was Professor of Geology at the University of Sydney (1891-1924). He led the first expedition to reach the South Magnetic Pole (1909) and distinguished himself in World War I. His Geological map of the Commonwealth of Australia and Explanatory notes were published in 1932.
Image courtesy of National
Library of Australia,
image number: nla.picimage number: nla.pic-
an10932811-47 


\section{Did know?}

\section{3: Geological surveys in Australia}

Since the mid-19th century, most states have had a Geological Survey office that produced maps and publications. Before World War II, there was a Commonwealth Geologist and Palaeontologist advising government, but the national geological survey, the Bureau of Mineral Resources of Geology and Geophysics (BMR), was only created by Sir Harold Raggatt in 1946 after a wartime push to find petroleum and useful minerals.

The BMR took responsibility for distant territories such as Papua New Guinea and the Australian Antarctic Territory and Commonwealth waters. The BMR changed its name to the Australian Geological Survey Organisation (AGSO) in 1992. Geoscience Australia was formed in mid-2001, following a merger between AGSO and the Australian Surveying and Land Information Group (AUSLIG). Geoscience Australia has a very broad role in meeting the geoscience needs of the nation to build Australia's future.

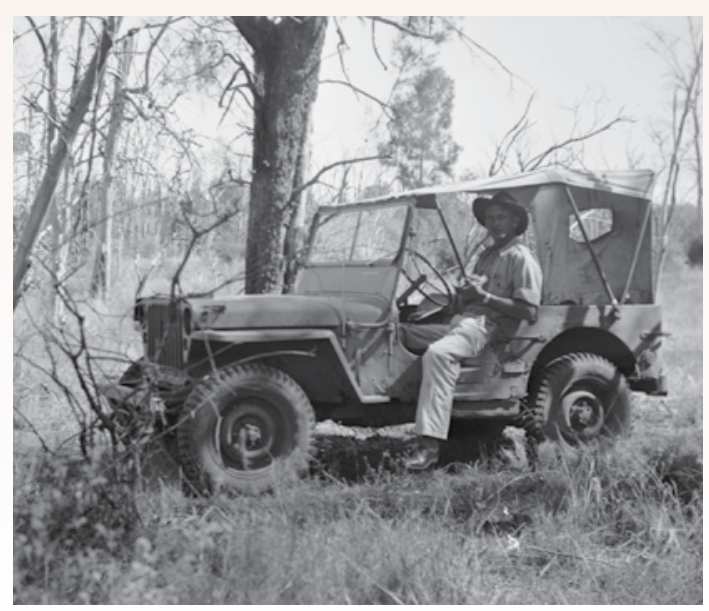

context for higher resolution regional geochemical studies and present a baseline for comparison for future geochemical surveys. Different processes emerge at the continental scale compared with the regional or local scale. In Australia, prolonged weathering and relative landscape stability have resulted in higher median silicon dioxide $\left(\mathrm{SiO}_{2}\right)$ and zirconium $(\mathrm{Zr})$ concentrations than in Europe, for instance.

\section{Surface geology}

The knowledge contained in the Surface Geology of Australia map (Figure 2.7) was compiled by numerous geologists and geophysicists over the past 150 years (Box 2.2). The first impression when examining this map is of the predominant yellow or light-green colours. These Mesozoic and younger sedimentary rocks make up more than $80 \%$ of the geology at the surface and illustrate the general tectonic stability of much of the continent from this time onwards. It is on this platform that Australia's regolith and landscape evolved (Chapter 5). Although Figure 2.7 shows the extent of Cenozoic cover to the shoreline, seismic and other data indicate that this cover extends offshore, forming basins that contain sediments in excess of $15 \mathrm{~km}$ in thickness, which accumulated during the breakup of Gondwana (Chapter 4).

The eastern seaboard, including the island of Tasmania, is a multicoloured patchwork of Paleozoic metamorphic, sedimentary and igneous rocks. They are revealed as highlands, due to the uplift generated by the formation of the Tasman and Coral seas. Eastern Australia is where the I-type (igneous sourced) and S-type (sediment sourced) granite classification concept was developed. These granites and associated rocks built the eastern margin of the old continent through a process of subduction rollback throughout the Phanerozoic. This rollback process, together with intermittent collision and orogeny, created the meridional grain of eastern Australia's geology. The Flinders Ranges, a Y-shaped region of uplifted Neoproterozoic to Paleozoic sedimentary rocks north of Adelaide (SA), attest to the influence of regional horizontal compression across the Australian Plate from the far eastern margin in New Zealand.

Across northern Australia, large areas of mostly Proterozoic metasedimentary rocks occur in the Kimberley, Pine Creek, Macarthur and Mt Isa areas. These basins were filled with vast sandsheets during a time when Earth's land surface was devoid of the stabilising influence of life (Chapter 3). The basins became the containers for major base metal and $U$ mineral systems (Chapter 8). A series of east-west mountain spines in central Australia is the remnant of the Devonian-Carboniferous Alice Springs Orogeny. Much later, this landscape shaped the first Australians and their beliefs (Box 1.1), with the development of ranges such as the spectacular Uluru (Ayers Rock) monolithan iconic postcard example of outback Australia (Chapter 5).

\section{Geological regions}

Stripping away the young Cenozoic cover from the surface geology map reveals the main geological regions of Australia (Figure 2.8). Geological regions are represented by the dominant outcropping to subcropping geology-for example, the Mt Isa 

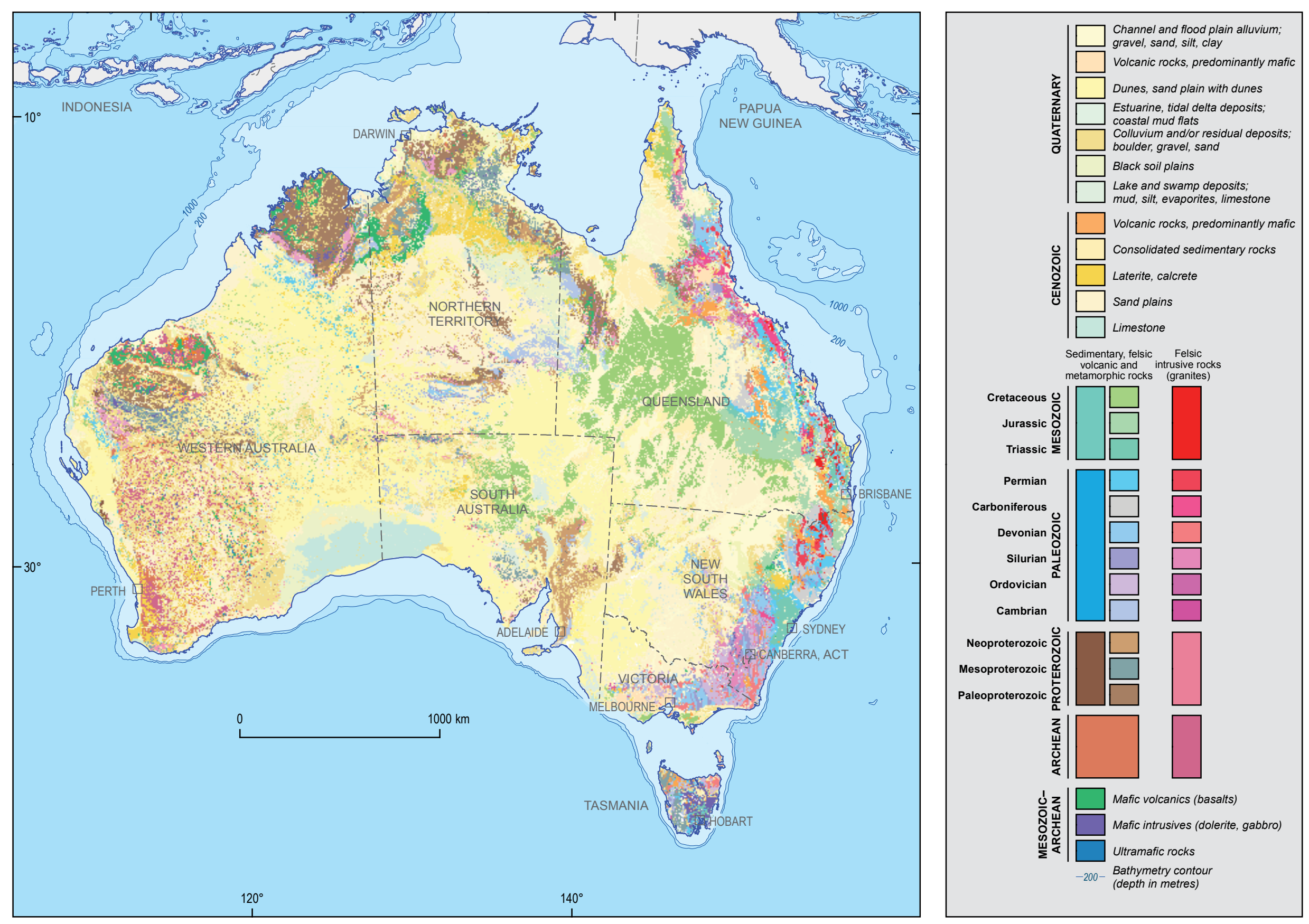

Figure 2.7: Surface Geological Map of Australia. Note the vast areas of pale-yellow rocks of Cenozoic cover and regolith (Chapter 5), 


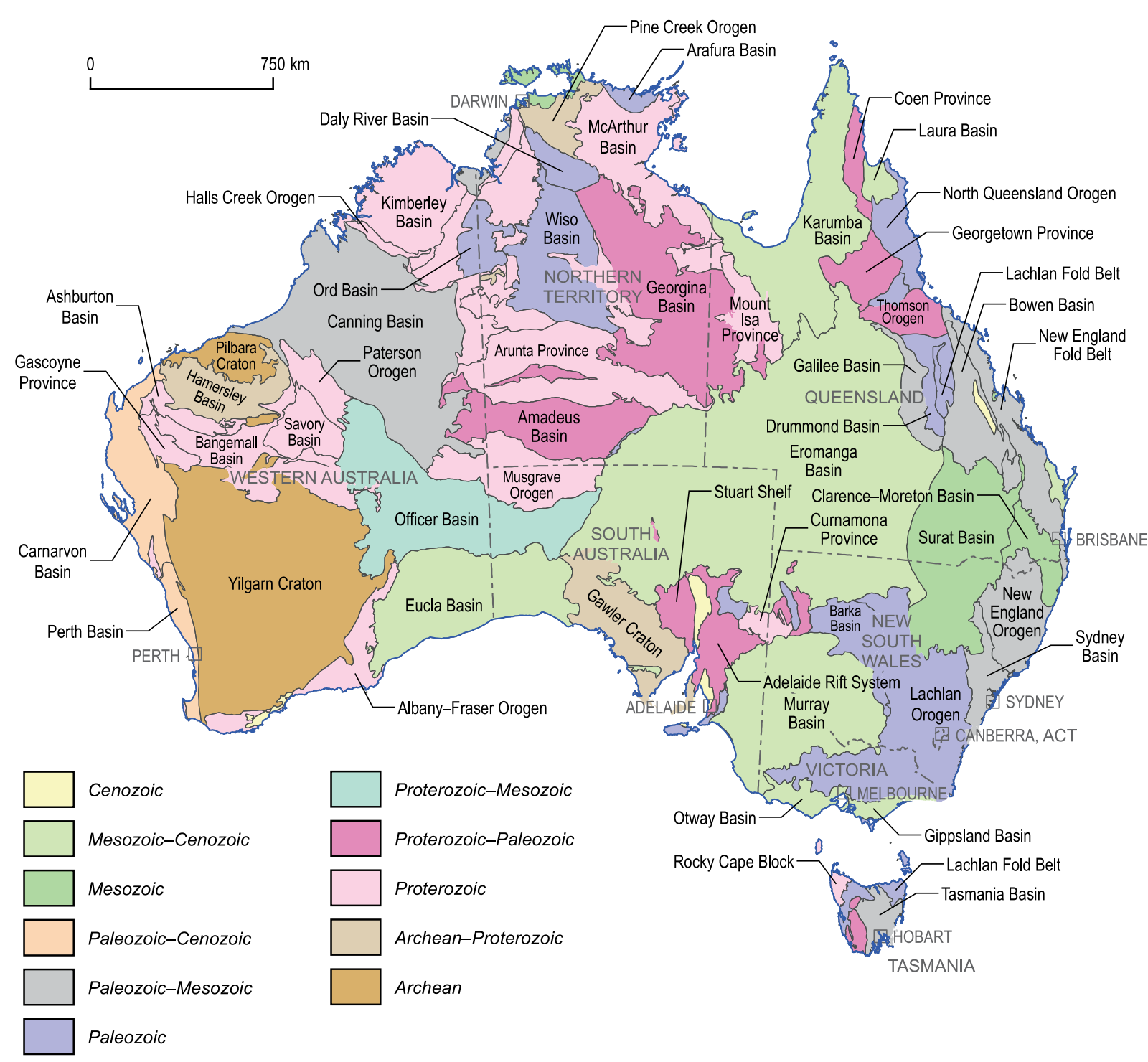

Figure 2.8: The basic building blocks of the continent are revealed in this map of major onshore geological regions of Australia, with the major cratons, inliers, orogenic belts and Phanerozoic sedimentary basins shown.
Inlier, Yilgarn Craton and Eromanga Basin. The geological regions are convenient geographic subdivisions of Australia. In a broad sense, a region may be thought of as the intersection of a three-dimensional geological province with Earth's surface.

The Archean rocks occur mostly in the west, with additional small exposures in the south and north. Proterozoic rocks extend as far east as the northeast coast, western Tasmania and Broken Hill. The Centralian Superbasin is a collection of late Proterozoic to Paleozoic basins that cover much of the centre and central west of the continent. The Paleozoic orogens (Lachlan to New England) in eastern Australia are partially covered by the vast Mesozoic Eromanga Basin, which covers around a fifth of the country. Unlike much of the regolith veneer visible in Figure 2.7, the Cenozoic Murray, Karumba and Eucla are discrete basins of significant thickness (up to several kilometres) and are thus retained on this map. The map illustrates the general trend of younger rocks in the east of the Australian continent.

\section{Basins}

Since the late Proterozoic breakup of the supercontinent of Rodinia, Australia has been the locus of numerous events that have resulted in the development of extensive and, in places, deep sedimentary basins (Figure 2.9). The process of basin formation is varied. Some basins formed in foreland settings as the various elements of the continent were shortened and mountain belts formed (e.g. Amadeus Basin in the centre, and the Sydney and Bowen basins in the east). Others are 
associated with rifting and continental separation of Australia and Antarctica (e.g. Otway and Gippsland basins). Some basins originated because of the lithospheric response to asthenospheric flow in the mantle. For example, the sinking of dense subduction slabs, or counter-flow from upwelling mantle plumes, can draw down the lithosphere. The deepening of certain eastern Australian basins, such as the Early Cretaceous Eromanga Basin and the Cenozoic Murray Basin, are viewed this way.

Many of the onshore basins that are located on the outer edge of the landmass have significant offshore extensions. Notable among these are the Bight, Northern Carnarvon and Arafura basins, all of which have much larger offshore dimensions than onshore (Figure 2.9). The basins of the North West Shelf region (WA) and the basins between Victoria and Tasmania host most of Australia's hydrocarbon production (Chapter 4). Some of the basins are under-explored, especially the vast Bight Basin, which stretches across the southwestern half of the country, and is the largest south-facing shelf on Earth. This coastal zone is exposed to the full force of the Southern Ocean, and is also a region of unique marine biodiversity (Chapter 6).

The central part of eastern Australia is a region with a vast number of overlapping basins that are concealed or partly concealed beneath the Mesozoic Eromanga Basin (Figure 2.9). The region has clearly been one of ongoing subsidence and basin formation since the mid-Paleozoic. These basins are important for Australia's coal and onshore hydrocarbon resources (Chapters 4 and 9), and are also becoming a focus for geothermal energy exploration (Chapter 10).

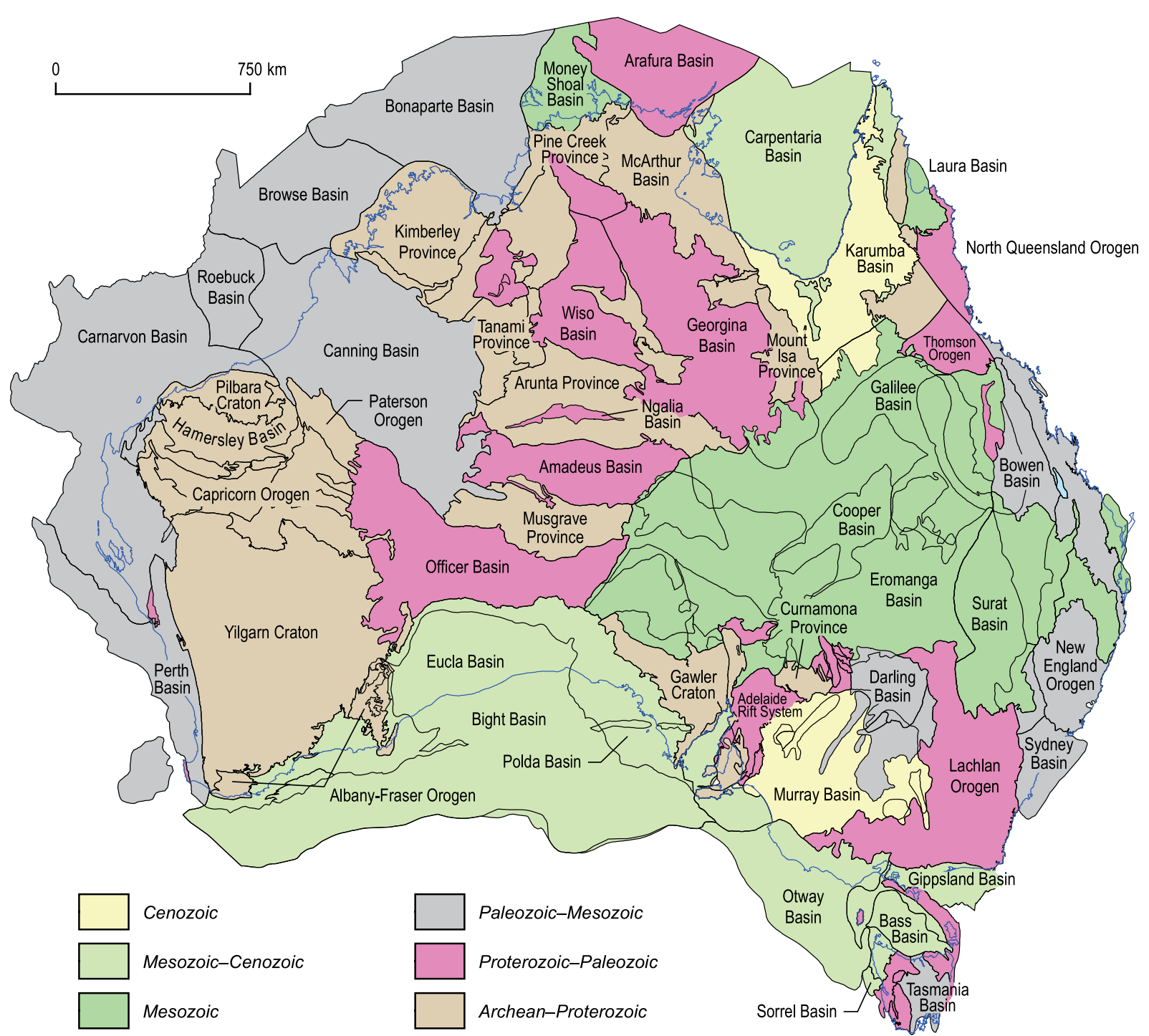

Figure 2.9: Major pre-Cenozoic basins of onshore and offshore Australia. In this map, the older basins beneath the Eromanga Basin are shown across eastern Australia. The onshore to offshore connections of the basins are also shown. Many of these named basins are hosts to Australia's producing, as well as potential, hydrocarbon and coal resources (Chapters 4 and 9). 


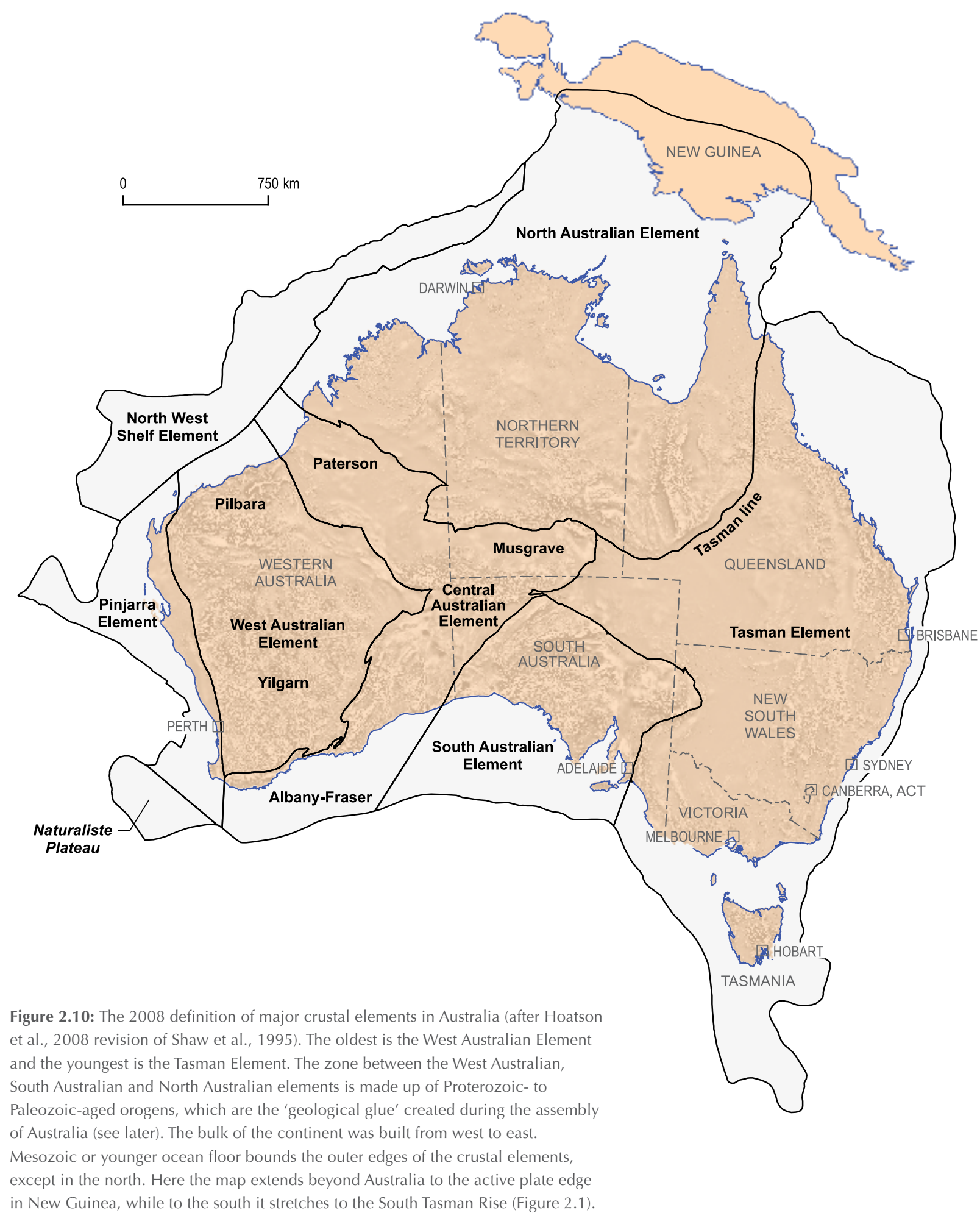

\section{Crustal elements}

Beneath the late Proterozoic and younger basins (Figure 2.9) lie the fundamental building blocks, or major crustal elements, of continental Australia. The interpretation of these elements and their boundaries has evolved over the past 100 years, and will continue to evolve as new data are acquired.

Edgeworth David produced the first tectonic map for Australia in 1911, which he updated and revised in 1931. In 1960, a solid geology map of Australia showed the continent with Cenozoic rocks removed (similar to Figure 2.8). Around 1970, Russian geologists published a tectonic map of Australia in their Great soviet encyclopedia. The Geological Society of Australia produced a 1:5 M scale tectonic map of Australia and Papua New Guinea in 1971. As part of an earth science atlas of Australia, the Bureau of Mineral Resources published the Major structural elements of Australia. This 1979 map divided the continent into five main groups of cratons and so-called covers: the Archean Craton, the North Australia Craton, Northeast orogens, Central Australian Mobile Belts and the Tasman Fold Belt.

In 1995, the Australian crustal elements map was produced, utilising the improvements in national-scale geophysics, geochemistry and geochronology. The map identified eight coherent 'mega-elements'. These mega-elements represent crust with similar geological and geophysical characteristics, within a common set of boundaries, which were interpreted to mark crustal-scale changes in composition and/or structural patterns. 


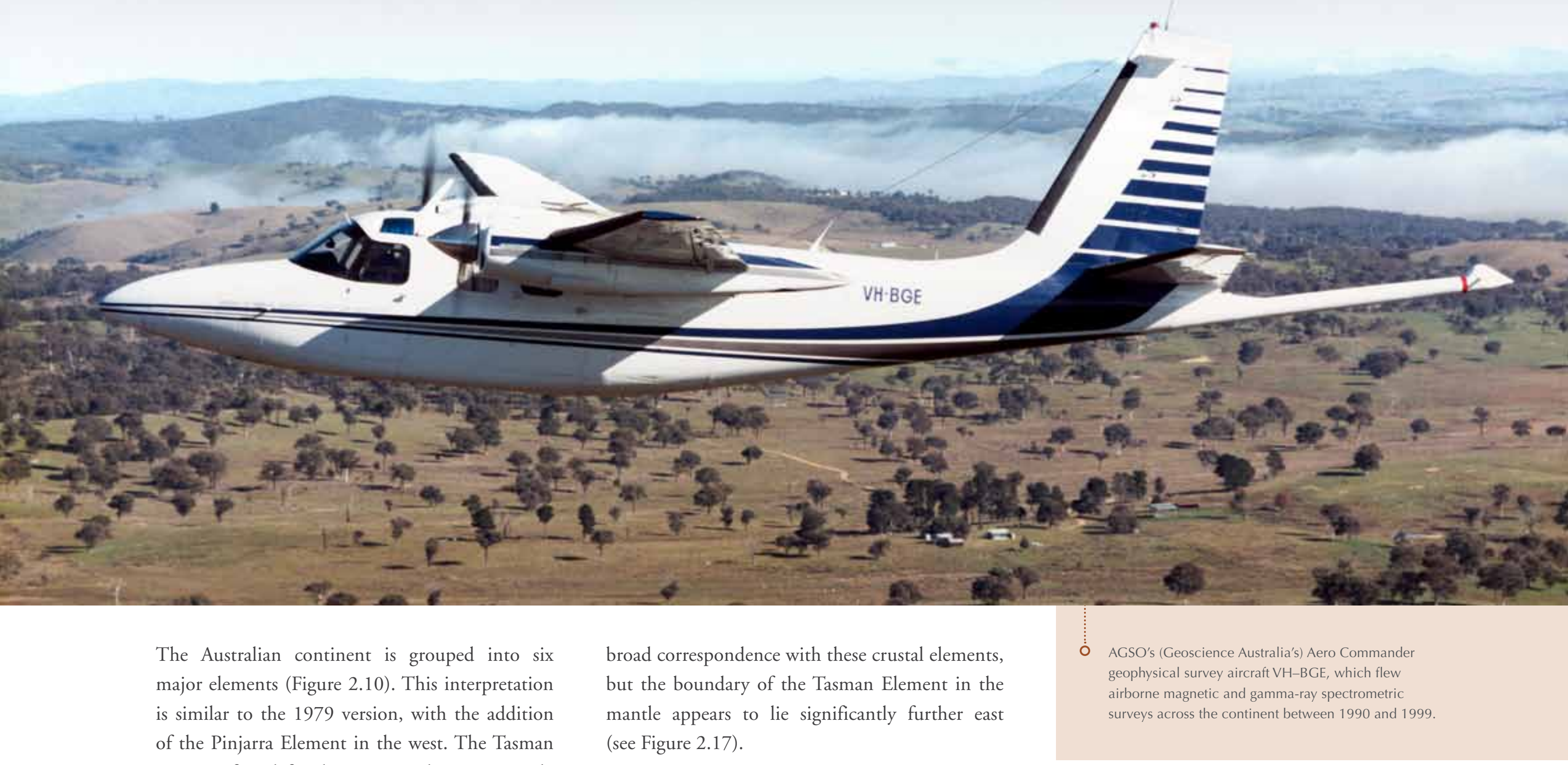
Line was first defined in 1951 as the most easterly outcrop of Precambrian rocks. This line has been redrawn many times, mostly on the basis of interpretation of geophysical datasets. Proterozoic rocks occur east of most proposed Tasman Lines, such as in northwest Tasmania and north-central Queensland. They are likely to be the basement to much of the Tasman Orogen, or as rifted remnants of the margins of Rodinia, a Neoproterozoic supercontinent (see below and Box 2.5) to which Australia belonged. Studies of the seismic structure in the mantle beneath Australia show a

The Central Australian Element is a zone of reworking of the older elements north and south, together with juvenile input during a series of rifting events. This element includes the Albany-Fraser Orogen and the Musgrave-Paterson Orogen. The North Australian Element, from the Kimberley region in the west to Cape York Peninsula in the east, consists of mostly Proterozoic rocks that were cratonised by $1550 \mathrm{Ma}$. The West Australian Element consists of the Archean Yilgarn and Pilbara cratons, which are separated by Proterozoic 


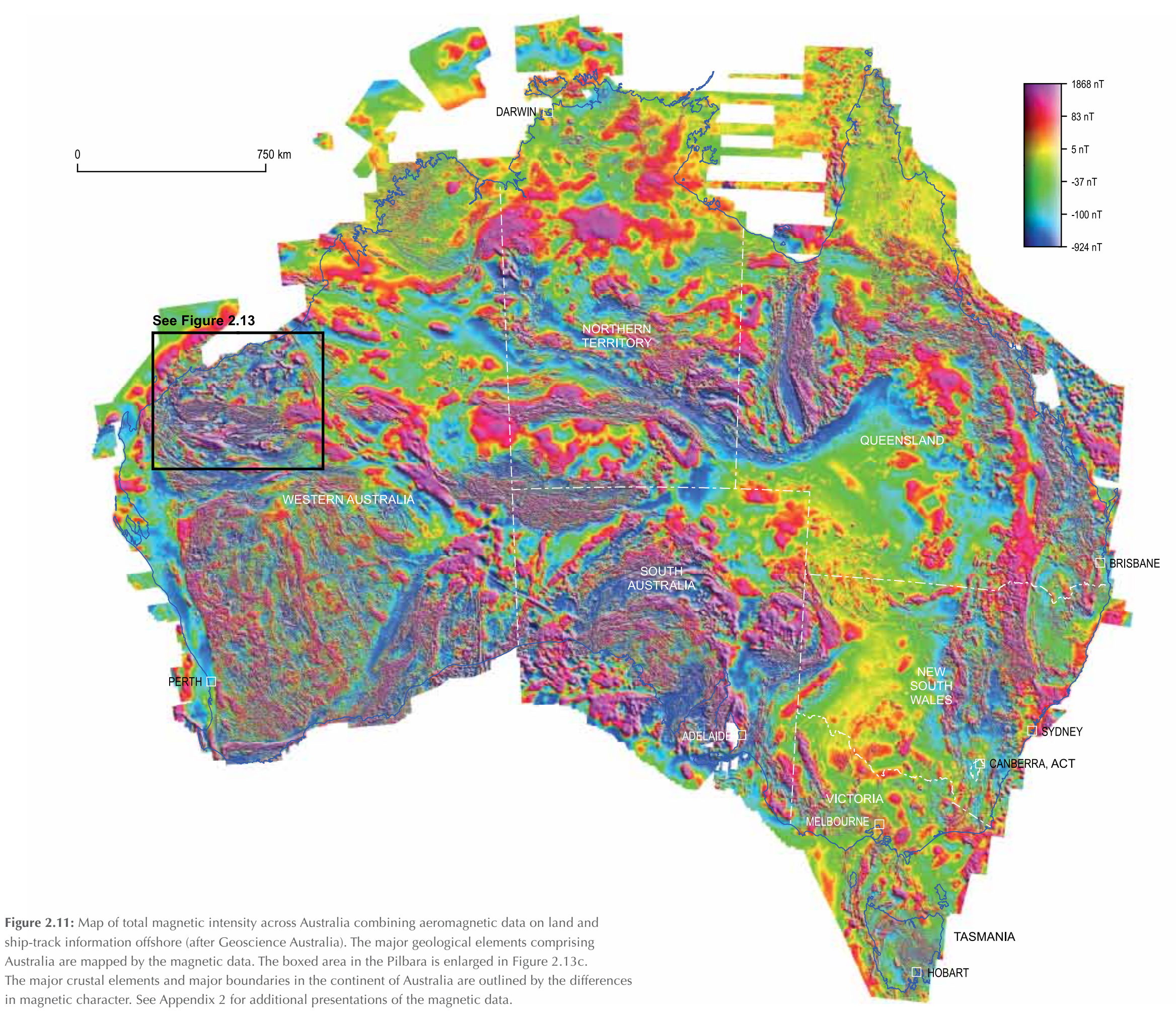




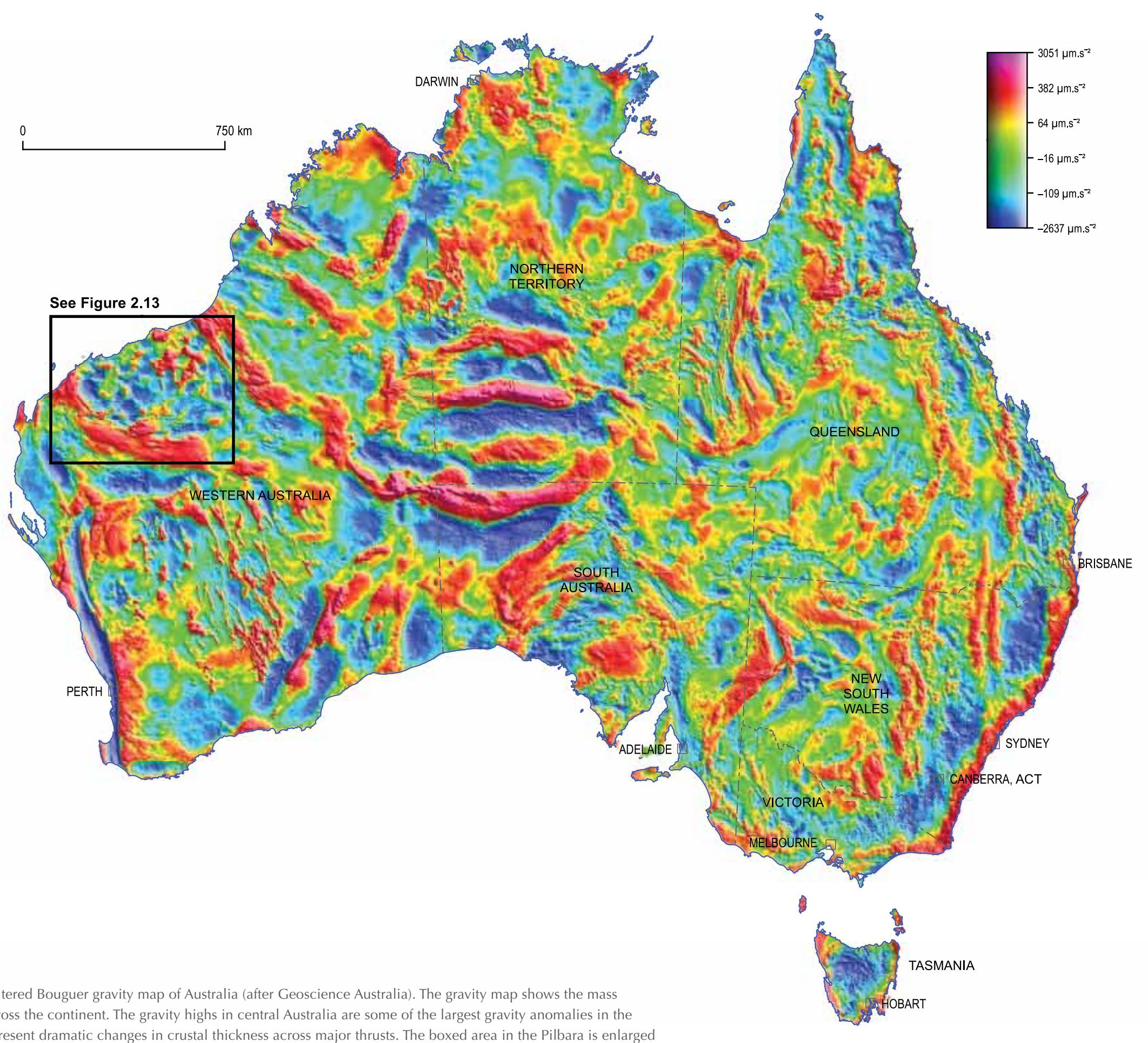

distribution across the continent. The gravity highs in central Australia are some of the largest gravity anomalies in the

world, and represent dramatic changes in crustal thickness across major thrusts. The boxed area in the Pilbara is enlarged

in Figure 2.13d. See Appendix 2 for additional presentations of the gravity data. 


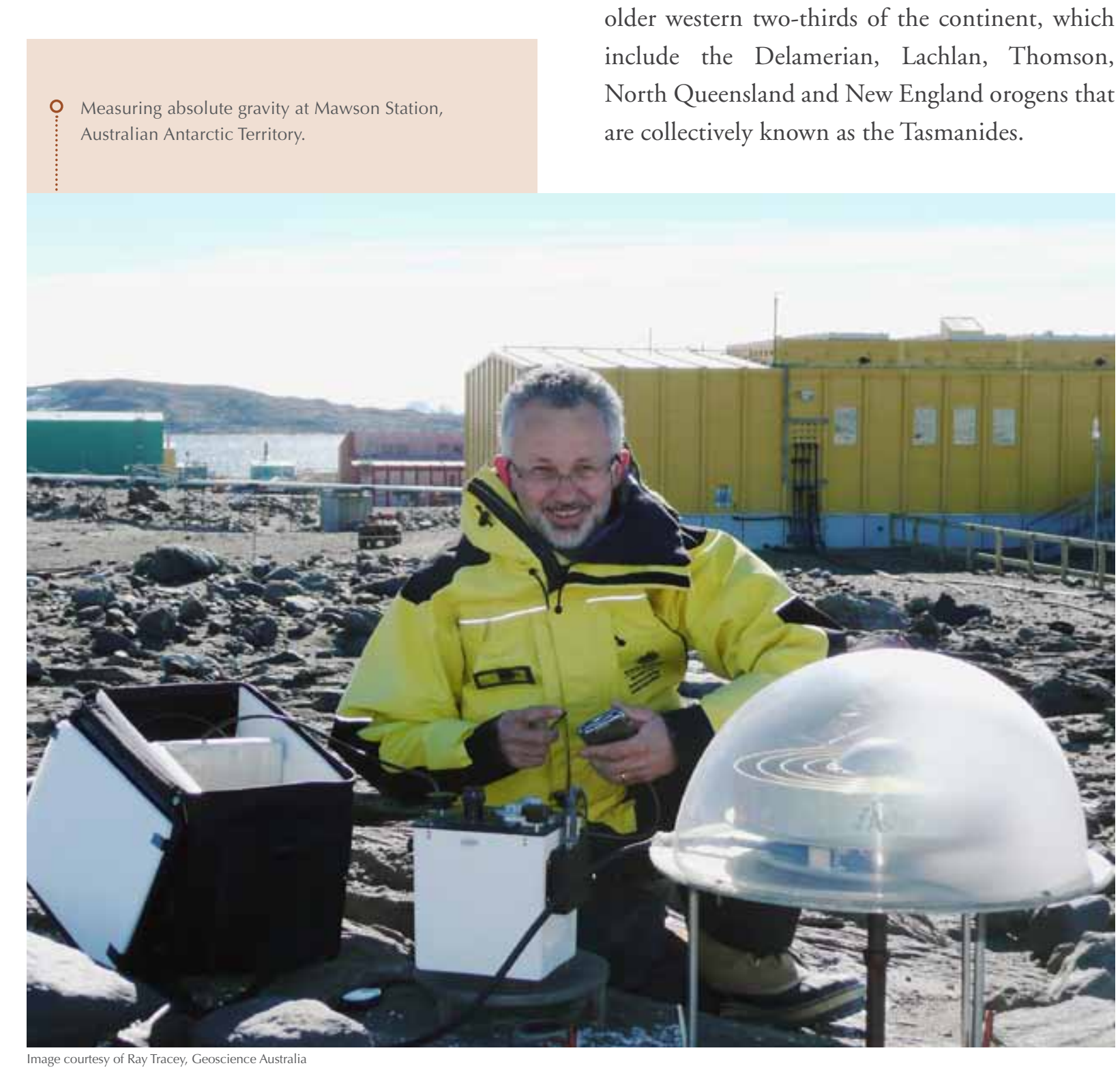

mobile belts. The Pinjarra Element comprises Proterozoic and younger reworking of the western margin of the continent. The South Australian Element consists of the Archean Gawler Craton and Proterozoic Curnamona Province, which have some geological affinities with the element to the north. The Tasman Element consists of a series of eastward younging orogens accreted onto the older western two-thirds of the continent, which include the Delamerian, Lachlan, Thomson, North Queensland and New England orogens that are collectively known as the Tasmanides.

\section{Australia's potential fields}

Around $80 \%$ of Australia is covered by surficial material (Figure 2.7) called regolith (Chapter 5). Its presence makes potential field geophysics an essential tool set for mapping the buried geology beneath. This extensive regolith cover has driven the collective efforts of the state and territory geological surveys and Geoscience Australia to acquire high-quality continent-wide airborne magnetic data (Figure 2.11). The gravity information is not as densely sampled, but many parts of the continent are sampled on a $1-2 \mathrm{~km}$ grid (Figure 2.12). The magnetic and gravity data are complementary, mapping different fundamental bulk rock properties (susceptibility for magnetism and density for gravity).

The potential fields reflect both the spatial distribution and the strength of variations in physical properties, so that longer spatial wavelengths are sensitive to anomalies at a greater depth. The gravity signal diminishes with the square of the depth, while the magnetic signal diminishes with the cube of the depth, which means that gravity is a 'deeper looking' technique. No single presentation satisfies all needs, and filtering the data is required to extract the different depth and textural information (see Appendix 2 for different presentations).

\section{Magnetics}

Magnetic data measure the variation in Earth's magnetic field, which is caused by differences in the magnetic susceptibility of the underlying rocks. Such data typically provide information 
on the structure and composition of the magnetic basement, which commonly has a distinctive magnetic signature characterised by the magnitude, heterogeneity and fabric of the magnetic response. When calibrated with known geology, terranes can be mapped under a cover of sedimentary rock and/or water, a technique that has proved valuable in Australia, given its extensive and deep cover (Figures 2.8, 2.9 and 2.10).

The total magnetic intensity map (Figure 2.11) shows a number of features in common with the filtered gravity map (Figure 2.12), but also a more distinct representation of texture linked to the major geological features. Major basement structures can be interpreted from consistent discontinuities and/or pattern breaks in the magnetic fabric. We see, for example, the distinct oroclinal swirl of structure around the southern end of the New England Orogen on the east coast. There are still a few areas with thick sedimentary cover where flight-line spacing is sparse, notably around the Simpson Desert in northeast South Australia, so that loss of detail here may not just be associated with cover. The sharp, jagged magnetic boundaries along the western borders of New South Wales and Queensland are often interpreted as the preserved salients and embayments created by the breakup of Rodinia. To the west, the old craton and province of the Gawler and Curnamona are circular in shape, and are fringed by younger mobile belts. The Yilgarn Craton makes up much of southern Western Australia, and it too has sharp magnetic boundaries from younger events, such as the Pinjarra and Albany-Fraser orogens, on its margins. a. Landsat (Figure 2.4)

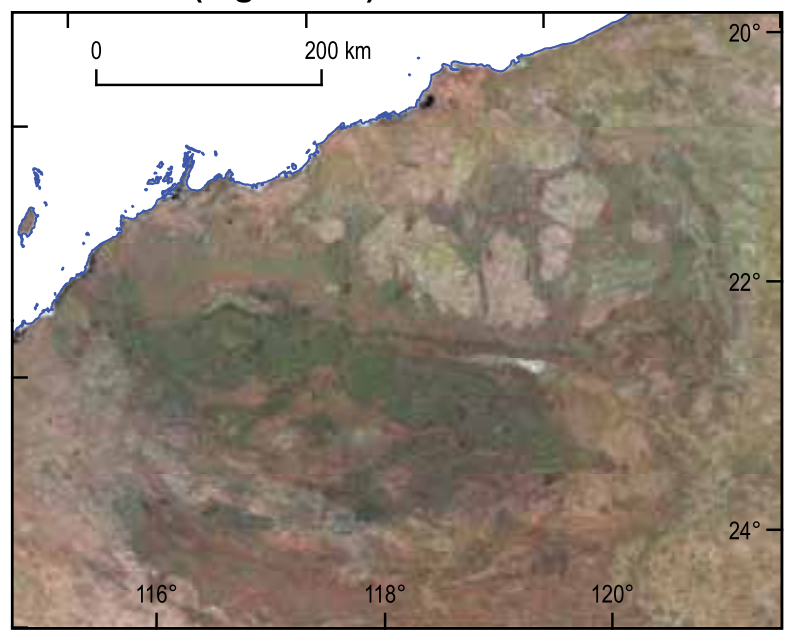

c. Magnetics (Figure 2.11)

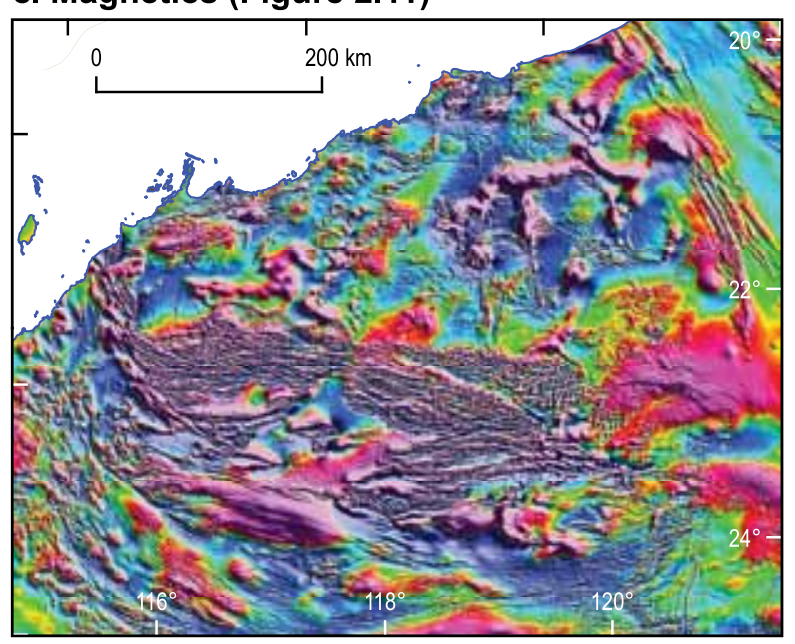

b. Gamma-ray spectrometric (Figure 2.5)

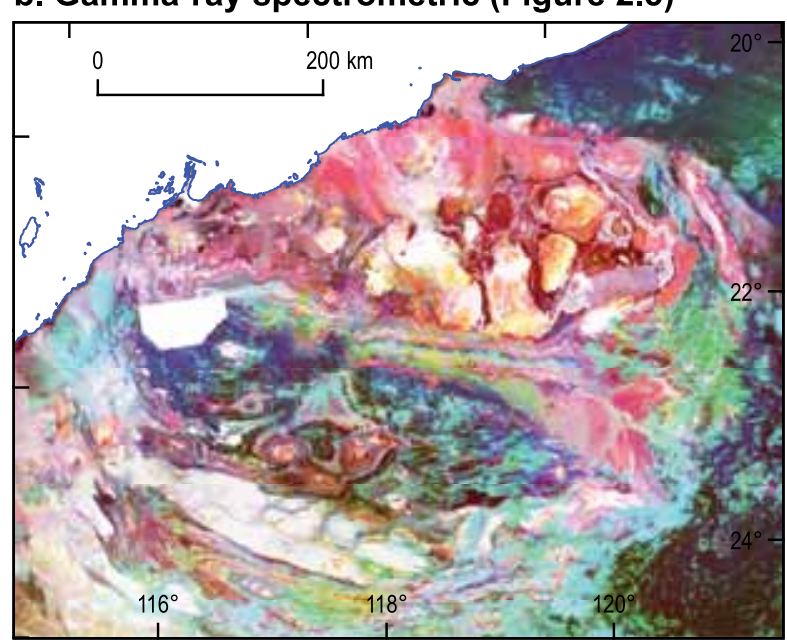

\section{d. Gravity (Figure 2.12)}

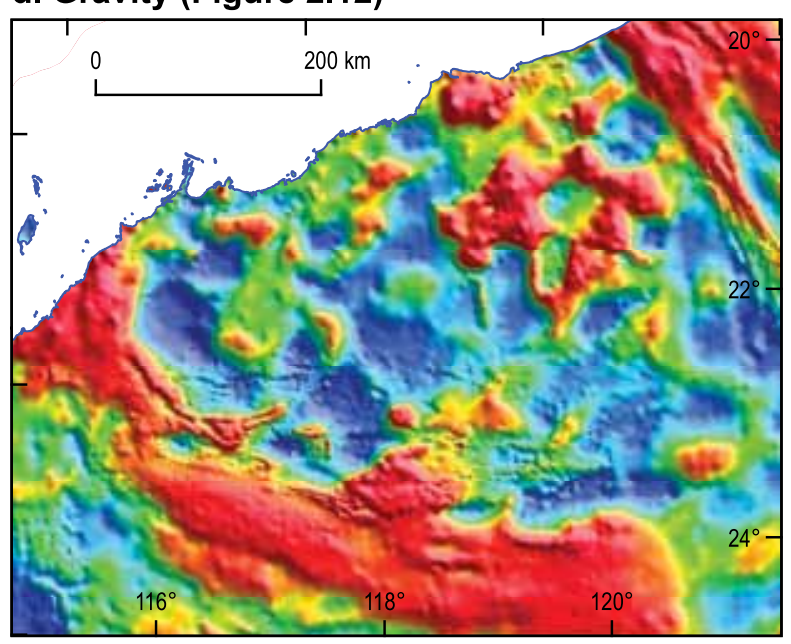

Figure 2.13: The North Pilbara Craton of Western Australia is a classic dome-and-basin map pattern for Mesoarchean geology. The exposed granite-cored domes are up to $50 \mathrm{~km}$ in diameter; they are enveloped by predominantly basaltic (greenstone) volcanic rocks. These rock types have distinctly contrasting properties, visible in the images. In contrast to the greenstones, the granites have high albedo (reflectance of light); high radioelement concentrations, particularly K (coloured red to white); low magnetisation; and low density. Covering the southern and eastern region are the Neoarchean volcanic and sedimentary rocks of the Fortescue and Hamersley basins (Figure 2.9). 


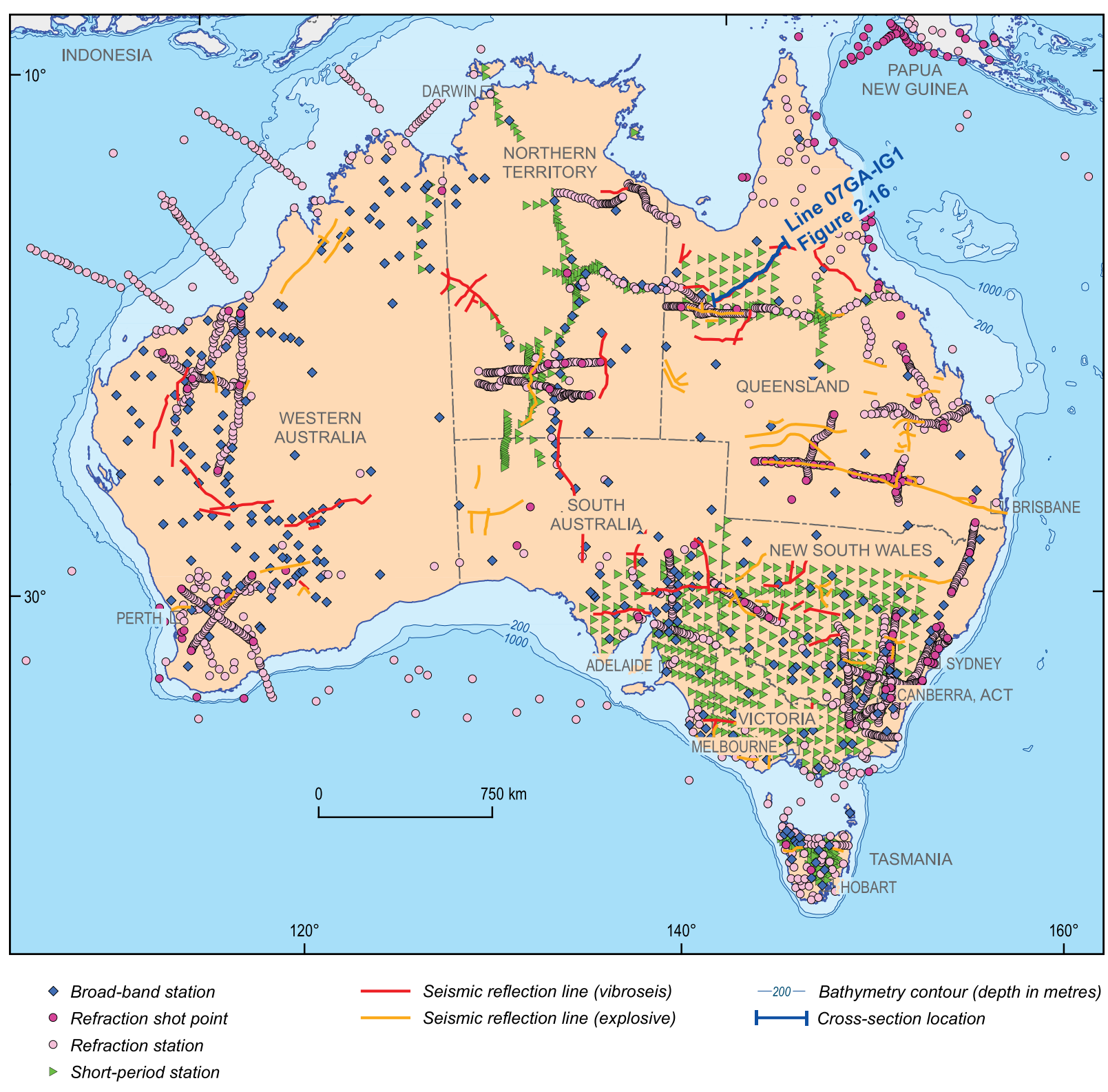

Figure 2.14: Both controlled-source and passive seismic techniques are systematically and regularly deployed across Australia. The major seismic reflection lines cross most of the major elements and their boundaries. A selection of the reflection profiles is presented in the Australian Common Earth Model (on DVD). Many of these onshore surveys have been acquired in the past decade, which has seen improvements in the processing and acquisition of data. The location of the seismic line in Figure 2.16, which crosses part of north Queensland, is also shown.

\section{Gravity}

Gravity data map subtle changes in Earth's gravitational field caused by variations in the density of the underlying rocks. The spatial resolution of gravity data tends to be lower than that of aeromagnetic data, but its ability to image anomalies at depth is better than magnetic data (Figure 2.12). Continental Australia has a gravity station spacing coverage of $11 \mathrm{~km}$. South Australia, Tasmania and part of New South Wales are covered at a spacing of $7 \mathrm{~km}$, and Victoria at approximately $1.5 \mathrm{~km}$. Over the past 15 years, the Australian, state and Northern Territory governments have funded exploration initiatives for the systematic infill of the continent at a grid spacing of $2 \mathrm{~km}$, $2.5 \mathrm{~km}$ or $4 \mathrm{~km}$ to provide improved coverage for areas of scientific or economic interest.

The current gravity grid was produced from 1.4 million onshore gravity stations. Data for the offshore region were extracted from a satellite altimetry dataset provided by the Scripps Institution of Oceanography, California. The gravity image links the Bouguer field on the continent to free-air gravity anomalies offshore. The full gravity field clearly displays the contrasts associated with the various cratonic elements, and considerable substructure is revealed when the longer wavelength gravity anomalies are removed by filtering (Figure 2.12). The group of alternating bands of east-west-trending low and high gravity anomalies in central Australia dominate the gravity image, and are associated with substantial localised changes in crustal thickness in the zone affected by the Alice Springs Orogeny. Similar bands of alternating north-south-trending gravity 
anomalies in eastern Australia are interpreted to be associated with a series of island arcs and a succession of Paleozoic accretionary events onto the evolving eastern margin of the continent. The major mineral province of Mt Isa (western Qld) has strong positive gravity anomalies that trend north-south, a tectonic grain imparted during the Mesoproterozoic. These trends are truncated in the south, seen by a sharp gravity gradient that most likely formed during the latest Proterozoic breakup of the supercontinent Rodinia, probably when Laurentia (North America) rifted from Australia to form the palaeo-Pacific Ocean. The contrasting Archean map patterns within the Pilbara Craton (ovoid) and the Yilgarn Craton (elongate) are evident in the gravity response to the distribution of dense mafic greenstone rocks.

\section{Australian lithosphere}

The nearly rigid outer skin of Earth is termed the lithosphere, which in Australia ranges in thickness from more than $200 \mathrm{~km}$, beneath the Archean cratons of Western Australia, to very thin at the active mid-ocean ridges of the Southern Ocean. With crustal and upper mantle components, the lithosphere sits upon the more ductile asthenosphere. The Australian lithosphere is moving more quickly than the asthenosphere beneath, driven by ridge push from the mid-ocean ridge in the Southern Ocean and slab-pull along the subduction zones to the north and east.

\section{Crust to mantle}

The uppermost layer of the lithosphere is the crust. A sustained program of active seismology using human-made sources, as well as passive

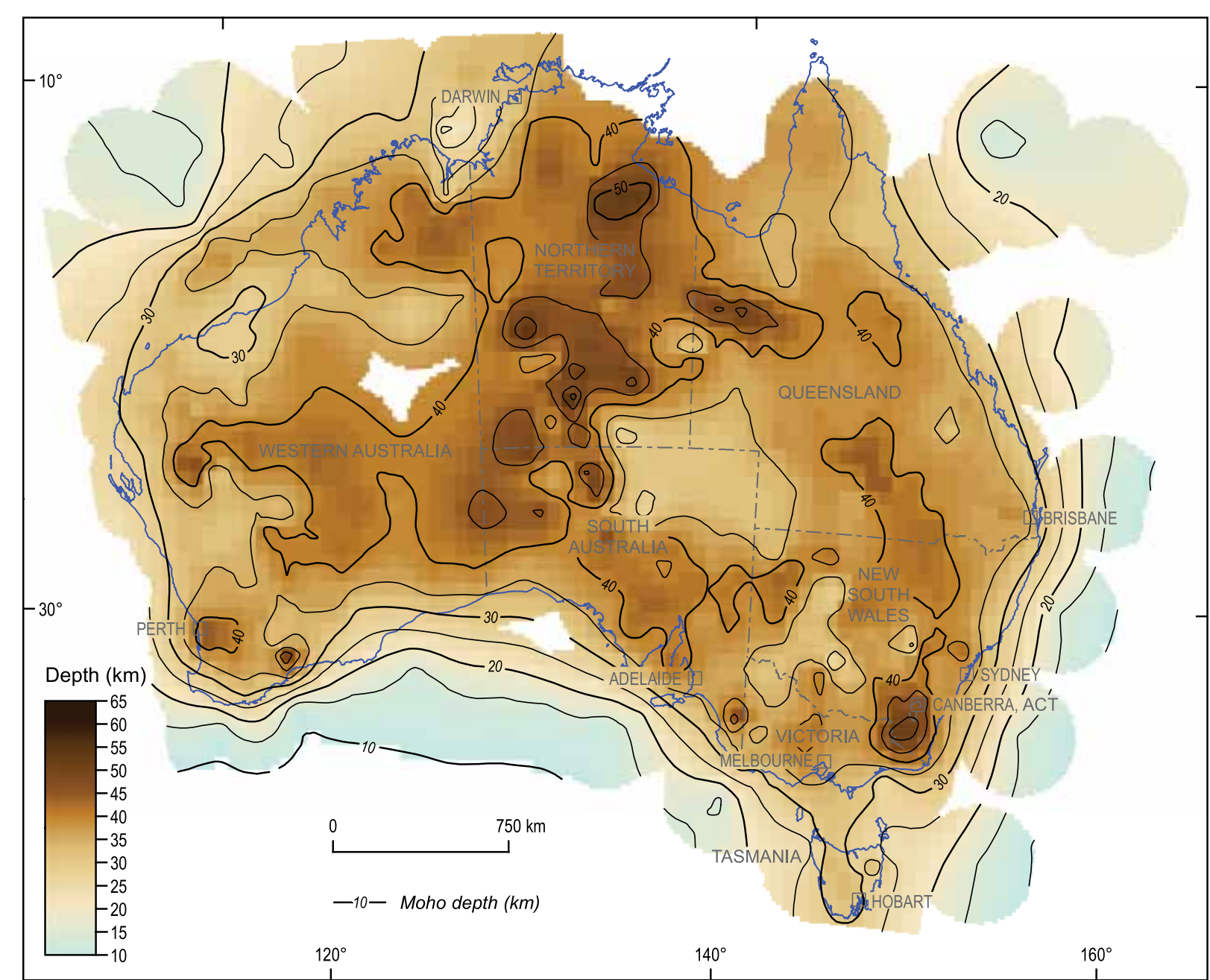

Figure 2.15: Contour map of crustal thickness (depth to Moho) in kilometres. The data are derived from seismic reflection, refraction and receiver function methods (Figure 2.14). The continent has an average crustal thickness of $38 \mathrm{~km}$, with a range in thickness from $24 \mathrm{~km}$ to $59 \mathrm{~km}$. There are a number of large gradients in crustal thickness, particularly in central Australia around longitude $132^{\circ} \mathrm{E}$. The Moho changes from nearly $60 \mathrm{~km}$ in the west to around $30 \mathrm{~km}$ in the east over a distance of only about $200 \mathrm{~km}$. The crust around Mt Isa and Tennant Creek in the North Australian Element is unusually thick $(50 \mathrm{~km})$, as is the crust beneath the 'high country' of the Snowy Mountains in southeast New South Wales. 


\section{- LAND-BASED DEEP CRUSTAL REFLECTION PROFILING ${ }_{\left(80 x_{2.3}\right.}$}

Australia was a pioneer in the use of land-based seismic reflection methods to probe the deep crust, with short reflection profiles conducted as early as the late 1950s. An ongoing acquisition program has been maintained over the decades by Geoscience Australia and its predecessors, with increasing sophistication in styles of experiment and recording.

The AuScope infrastructure initiative, launched in 2007 by the Australian Government, has enabled extra seismic reflection coverage to be acquired in South Australia, Victoria and Western Australia. More than $17600 \mathrm{~km}$ of deep seismic reflection profiles have been acquired across the continent (not including marine surveys).
Explosions were used as the energy source until 1998, with major surveys across southern Queensland and in central Australia. The establishment of the ANSIR Major National Research Facility for Earth Sounding in 1997 provided heavy-duty vibrator trucks and digital recording equipment, which were employed in a number of projects across the country to explore lesser known geological provinces.

The survey along the remote and regolith-covered region of north Queensland shows a remarkable range of structures through the crust, including major changes in seismic character, unknown sedimentary basins, possible sutures and a clearly defined sharp Moho (Figure 2.16).
The result of this work is an extensive nationa coverage across many of the continent's major structures. Such information helps in understanding the crustal architecture in the context of resource exploration, and provides depth control on the evolution of the Australian continent.

Processing deep-crustal seismic data is different from processing conventional sedimentary basin seismic data. The hard rock environment has relatively high P-wave velocities at shallow depths, and commonly has steeply dipping geology. Reflections from the deep crust also tend to be less coherent. The improvements in imaging have been made by use of better imaging algorithms, as well as more data channels per source location (data fold).

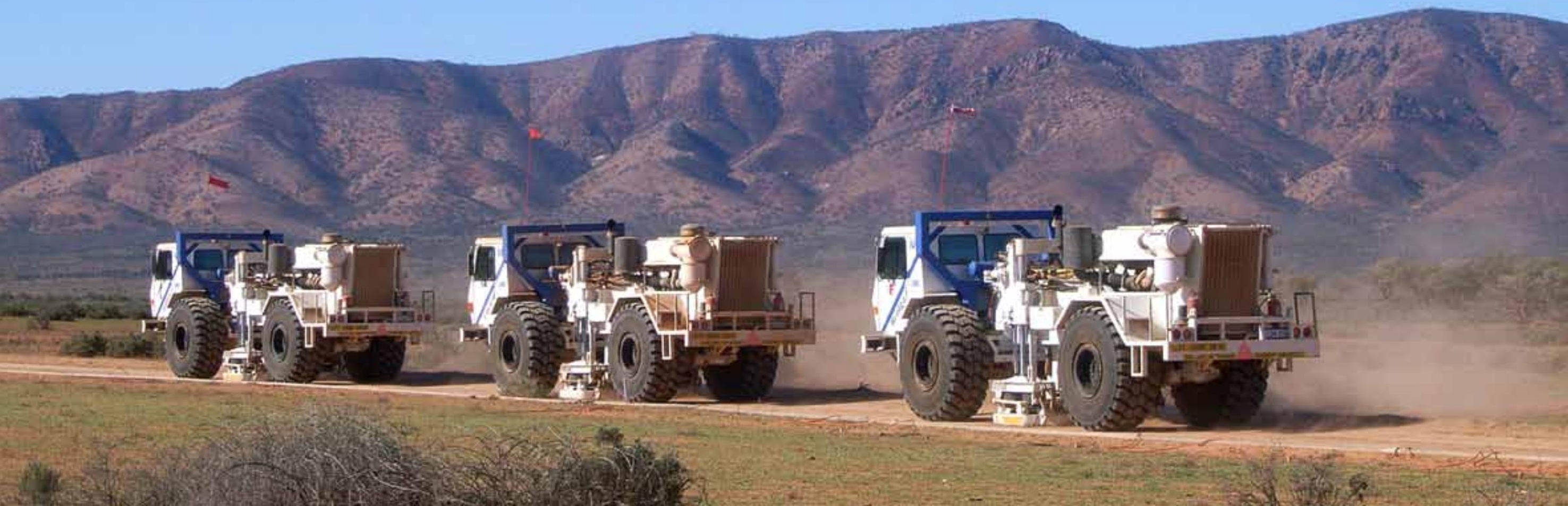


sources from earthquakes generated at subduction zones surrounding Australia and further afield, has provided a comprehensive view of the thickness and internal structure of the crust across Australia (Box 2.3). The extensive coverage of the continent is indicated in Figure 2.14, which shows the locations of seismic stations for reflection, refraction and passive seismic studies across Australia.

Various styles of seismic data analysis were employed to generate a new map of the crustal thickness across the continent. For consistency with earlier studies, the seismic Moho is taken at the base of the zone where seismic wavespeeds reach mantle values (e.g. above $7.8 \mathrm{~km} / \mathrm{s}$ for $\mathrm{P}$-waves). This definition may not correspond to the petrological Moho in terms of mantle rocks, and the transition from crust to mantle is gradational in a number of places across the continent. The combination of results from numerous deep seismic reflection, refraction and receiver function profiles has yielded the new map (Figure 2.15). The Australian continental crust, excluding the thinned margins, has an average thickness of $38 \mathrm{~km}$, with a range from $24 \mathrm{~km}$ to $59 \mathrm{~km}$. The clarity of the crustmantle boundary in the seismic data varies. In some terranes, like the Proterozoic region between Cloncurry and Croydon, north Queensland, the boundary is 'knife' sharp (Figure 2.16). A similar clear Moho is evident beneath the Archean Yilgarn Craton. In other areas, the boundary is difficult to define, such as in the Proterozoic Curnamona Province and the Archean-Proterozoic Gawler Craton (Figure 2.8). The crust-mantle boundary can have significant localised topography, with distinct offsets of more than $10 \mathrm{~km}$ due to large

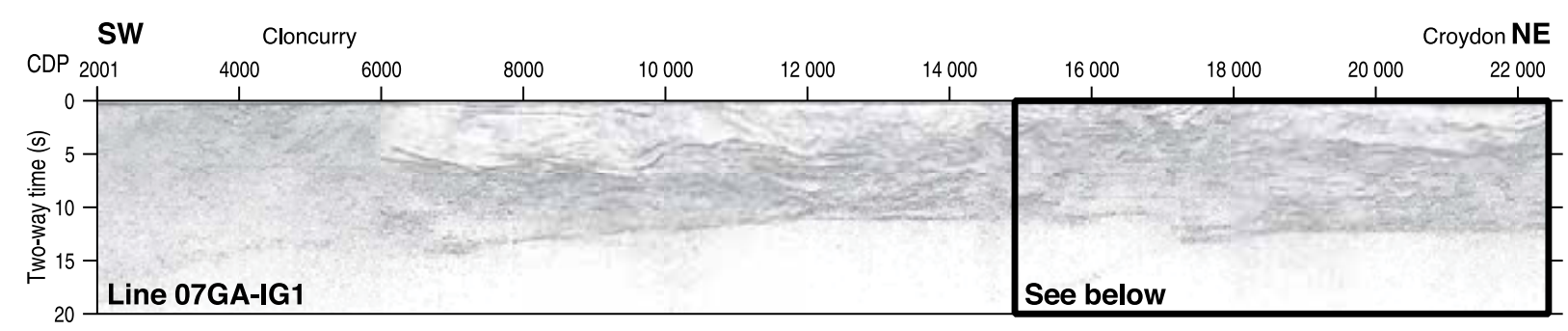

$50 \mathrm{~km}$

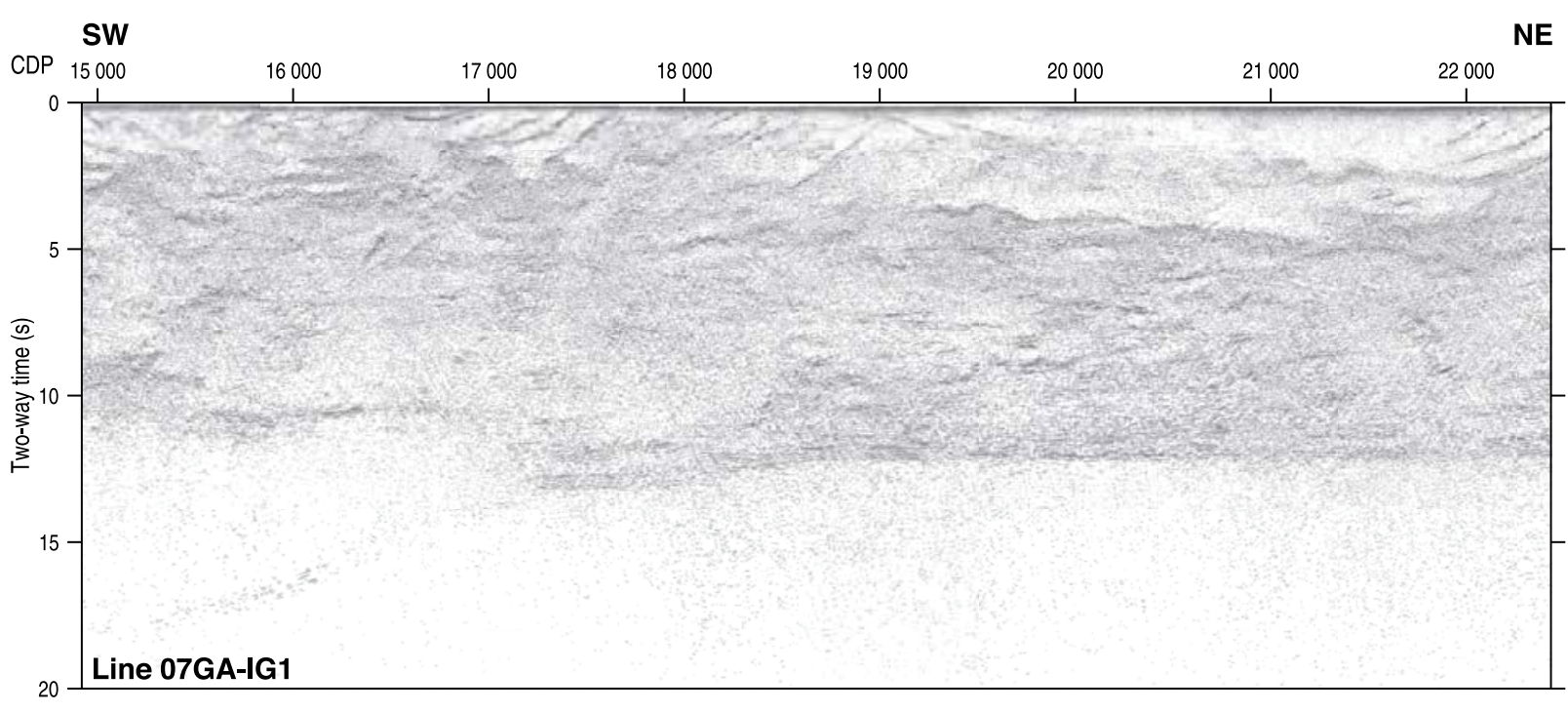

$50 \mathrm{~km}$

displacements on presumed faults (e.g. in north Queensland (Figure 2.16) and central Australia). There are also steep horizontal gradients in crustal thickness, particularly in central Australia.

The general pattern for post-Archean crust is towards thinner crust with decreasing age. This relationship has been interpreted to be associated with magmatic underplating, with the crust being accreted successively from below. This agethickness relationship does not hold for Archean crust, much of which is currently relatively thin, being around $30 \mathrm{~km}$ beneath the Pilbara Craton
Figure 2.16: Full crustal reflection profile between Cloncurry (left) and Croydon (right) in north Queensland carried out with vibrator sources (seismic line 07GA-IG1). Lower image shows a detailed view of the region in the box. The frame displays 20 seconds of record (i.e. approximately $60 \mathrm{~km}$ in depth). The migrated section shows contrasting seismic character of different crustal blocks. The Mt Isa Province has a seismic character that is diffuse, and the depth to Moho appears gradational or is poorly defined; the crust is at least $50 \mathrm{~km}$ thick (Figure 2.15). To the northeast, a major crustal boundary is crossed and the NumilAbingdon seismic province is imaged with a sharply defined Moho and a well-developed series of seismic features. Note the Moho step towards the northeast end (detailed lower image); this is where a reflector extends into the mantle and the Moho is offset by ca $10 \mathrm{~km}$. The features are interpreted as a fossil subduction zone. For more images and interpretations, see the Australian Common Earth Model (on DVD). 

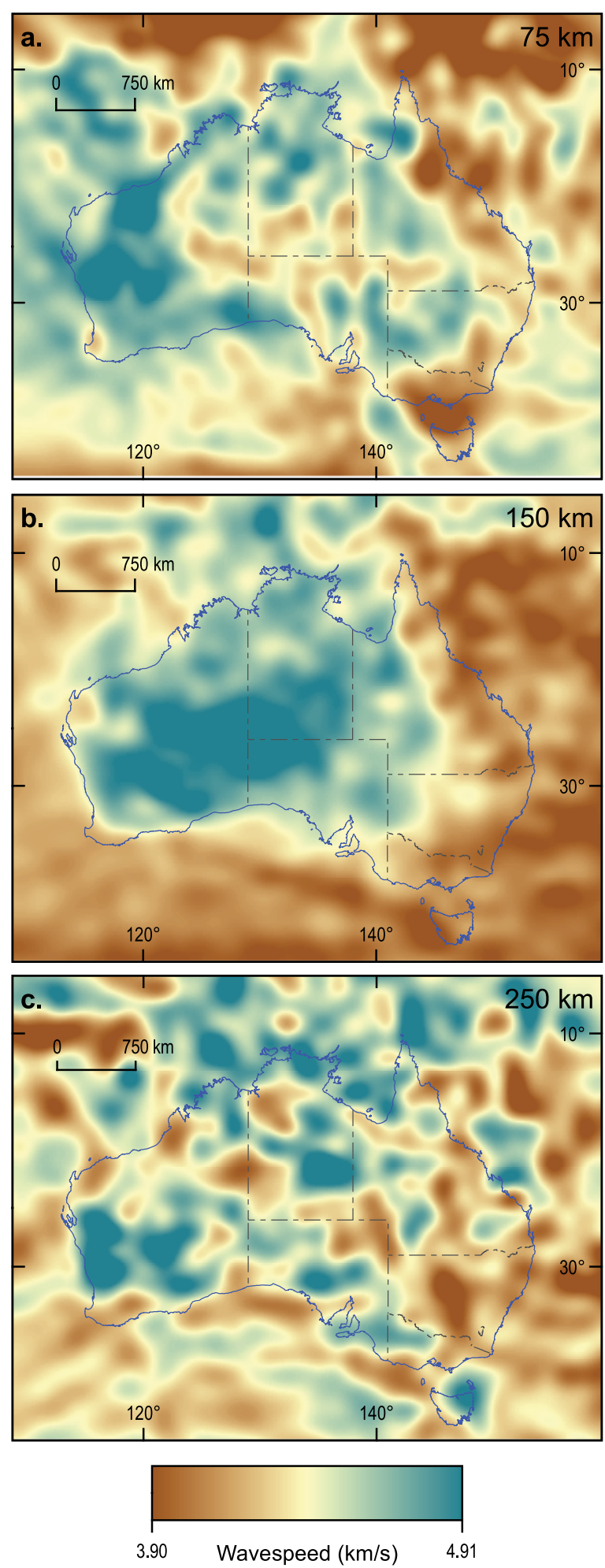

and around $38 \mathrm{~km}$ beneath the Yilgarn Craton. The thickest crust is under the North Australian Element. Interestingly, the Mt Isa region has anomalously thick crust of around $55 \mathrm{~km}$, and it also has a large volume of high-density material (Figure 2.12). The thinnest crust occurs beneath Tasmania (Figure 2.15).

Over the past 30 years, a series of long reflection seismic transects has been acquired (Figure 2.14). One series of surveys transects the crust from the Lord Howe Rise in the east some $2000 \mathrm{~km}$ to central-west Queensland. Many of the land surveys were high-quality vibroseis sourced with up to 22 seconds two-way-time recording that provided information on the crust and uppermost mantle. The total line length for onshore deep-seismic reflection surveys in Australia is $17600 \mathrm{~km}$.

More recently, magnetotelluric (MT) data have been added along many of the major seismic transects. This passive technique measures natural electrical and magnetic fields of the crust and mantle and is used to map major boundaries and different crustal domains. A deep conductive zone extends north-south from east of Mt Isa in the north to the eastern Flinders Ranges in the south. This zone approximates the boundary between the mostly older western and central Australian

Figure 2.17: A representation of the 3D variation in seismic wavespeed maps of the upper mantle through perspective view of depth slices at $75 \mathrm{~km}, 150 \mathrm{~km}$ and $250 \mathrm{~km}$. The three maps are displayed with a common seismic velocity scale, with the neutral tone representative of continental upper mantle structure. The red-brown zones have slower wavespeeds, probably due to the effects of higher temperatures or the presence of volatiles. The blue areas have faster wavespeeds and reveal the extent of the deep lithospheric keels of the continent. crust and the generally younger eastern Australia crust. Anomalous zones of enhanced crustal conductivity have been mapped beneath some of the major mineral systems, such as Olympic Dam and Kalgoorlie (Chapter 8).

Each new deep seismic and magnetotelluric survey discovers something. Major crustal boundaries are imaged through the entire crust, and some penetrate the Moho, leaving signatures interpreted as fossil subduction zones (e.g. Figure 2.16). Some of these deep structures are also spatially associated with Australia's major mineral deposits, such as beneath Mt Isa, Olympic Dam and Kalgoorlie (Chapter 8). The quest for mineral wealth is one of the principal drivers behind these deep surveys.

The regular release of offshore acreage is a key part of the Australian Government's strategy to encourage investment in petroleum exploration. The acreage release involves the delivery of seismic data and their interpretations in selective regions of the Australian margin. The 2011 release areas were located in Commonwealth waters offshore from the Northern Territory, Western Australia and Victoria (Arafura, Bonaparte, Browse, Roebuck, Carnarvon, Perth, Otway and Gippsland basins).

The offshore north and northwest region is a world-class gas province with significant oil accumulations. The region includes the offshore and marginal basins of the Arafura Sea (Carpentaria, Arafura and Money Shoal basins) and the North West Shelf (Bonaparte, Browse, Offshore Canning, Roebuck and Carnarvon basins and Wallaby Plateau) (Figure 2.9). Cumulatively, the North West Shelf basins comprise the Westralian 
Superbasin, a thick Late Paleozoic, Mesozoic to Cenozoic sedimentary succession related principally to the fragmentation of Gondwana (Chapter 4).

Under the UN Convention on the Law of the Sea, regional marine seismic data, together with potential field data, have been acquired across Australia's entire marine claim. These data were instrumental in defining Australia's limits (Chapter 1). They also reveal how the continent and its margins developed and evolved (Chapter 4).

\section{Upper mantle and lithosphere- asthenosphere boundary}

The Australian Plate is bounded by belts of earthquakes along the Indonesian arc, through New Guinea and then down through the TongaKermadec arc and New Zealand to join the mid-ocean ridge system south of Macquarie Island (Figure 2.1). These earthquakes have been exploited in a variety of studies of the structure beneath Australia, using both refracted body waves and the large late surface waves recorded at the few permanent and many temporary stations across the continent. The frequency of earthquakes is greatest to the north and east, but the southern events provide very useful additional information.

The earthquake signals are exploited in seismic tomography to extract images of the $3 \mathrm{D}$ shear wavespeed distribution beneath the Australian region. The reliability of the results depends on the density of paths between sources and receivers, and especially on a sufficient number of crossing paths. The result is reliable for most of the Australian

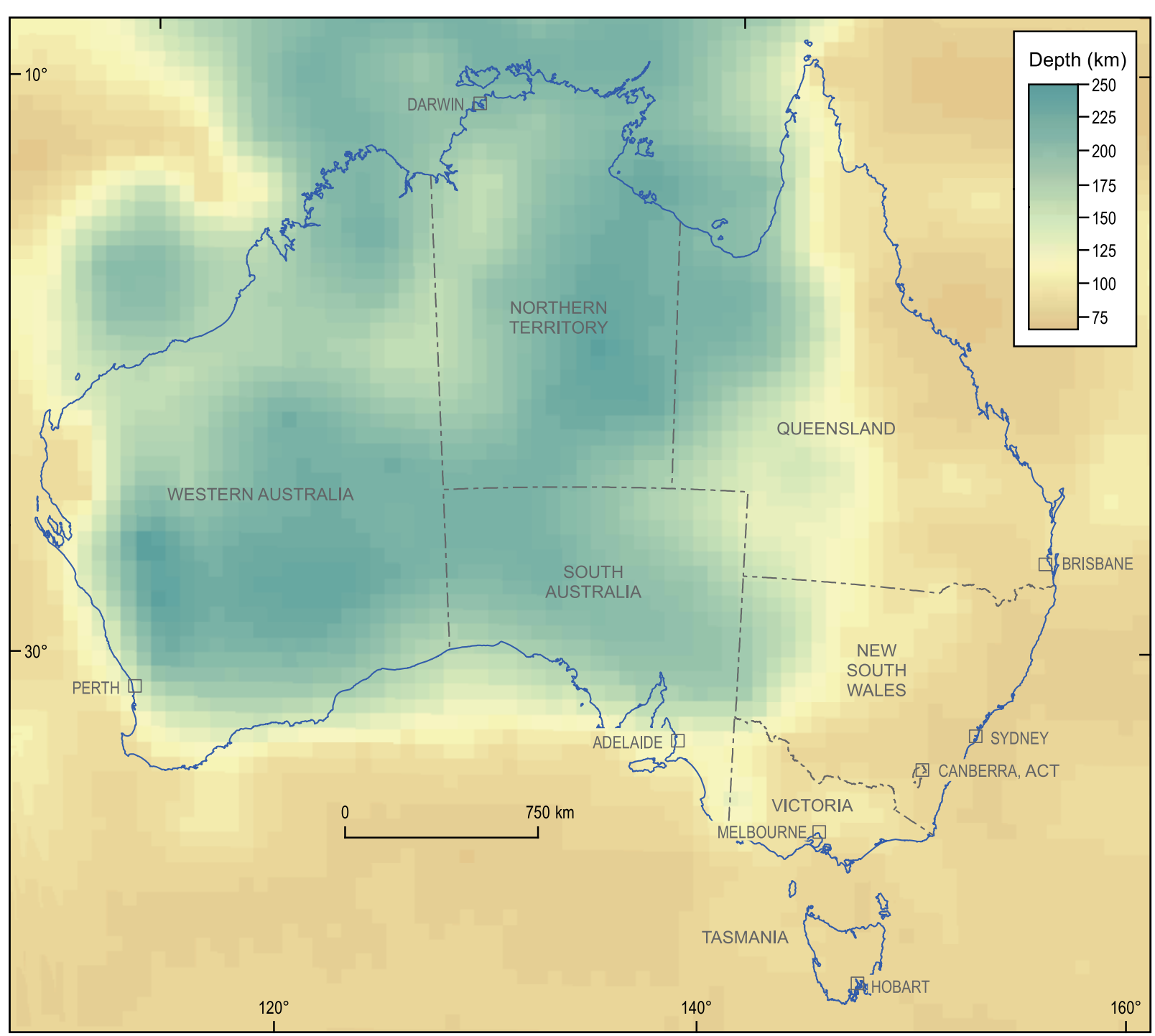

continent and the Tasman Sea to the east, but the absence of western sources means that coverage to the west of Australia is limited. Thanks to systematic coverage of the continent with portable seismic instruments undertaken since 1993 by The Australian National University, Canberra, the resolution of mantle structure is of the order of $200 \mathrm{~km}$ horizontally and $30 \mathrm{~km}$ vertically.
Figure 2.18: Estimate of the depth to the base of the lithosphere derived from various seismological data. The map shows the mostly ca $200 \mathrm{~km}$-thick lithosphere in the western two-thirds of the continent. The thickness of lithosphere beneath the Tasman Element in the east is ca $100 \mathrm{~km}$ or less, which is similar to the global average for continents. 


\section{Did know?}

\section{4: Deep carbon}

Diamond is the high-pressure allotrope (crystal form) of carbon. Most diamonds come from areas located above the edges of thick lithospheric keels of Archean cratons, such as the Kaapvaal Craton in South Africa and the Slave Province in Canada. If lithospheric depth is one main control on diamond formation, then does the thick lithosphere under Proterozoic-aged central Australia suggest that these regions and along their edges may be the place to look for them?

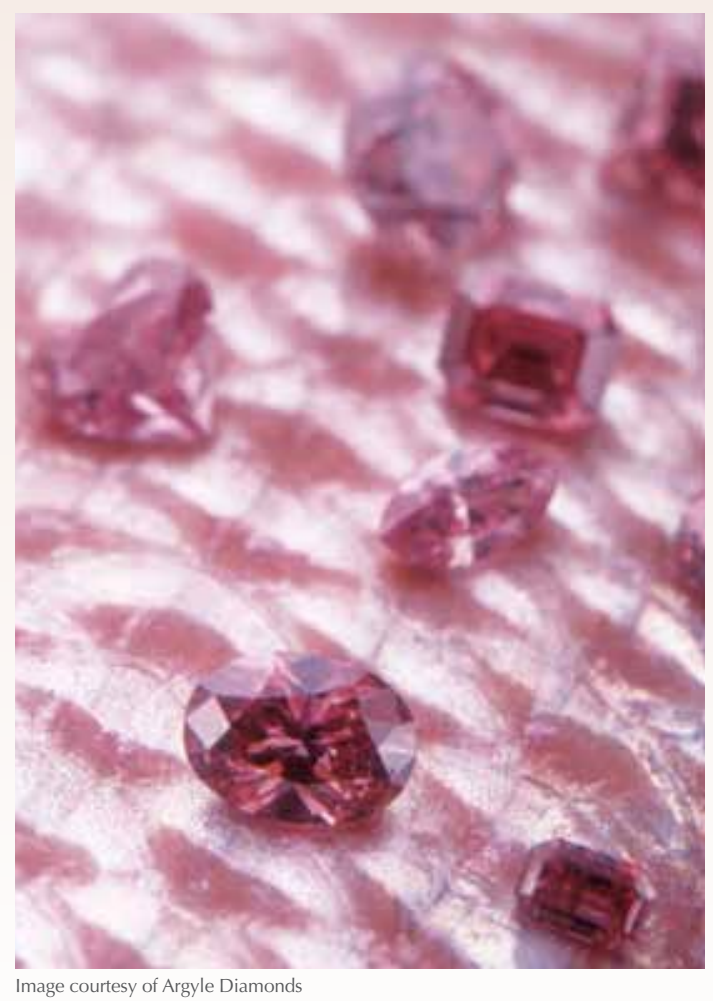

Argyle, in the Kimberley of Western Australia, produces more than $90 \%$ of the world's pink diamonds. These rare and precious gems have an intensity and vibrancy of colour not seen in any other diamonds.
The shear wavespeed (or velocity) is strongly dependent on temperature, and the base of the lithosphere is generally assumed to occur at mantle temperatures around $1300^{\circ} \mathrm{C}$. A striking feature in the $3 \mathrm{D}$ images of shear wavespeed is the strong contrast between fast wavespeeds (blue-green in Figure 2.17) in central and western Australia and slower wavespeeds (brown in Figure 2.17) to the east. This divide is most clear between $125 \mathrm{~km}$ and $200 \mathrm{~km}$ depth. The fast zones lie beneath the ancient cratons, whereas slower wavespeeds are seen beneath the eastern Phanerozoic belts and particularly beneath the Tasman Sea. At shallower depths, the fast wavespeed domains in the uppermost mantle are broken up in the areas of more recent deformation (Paleozoic), such as central Australia. The slow wavespeeds across the centre at $75 \mathrm{~km}$ depth are difficult to explain, and the suitable combination of thermal or compositional structure remains a question of considerable scientific interest. This zone also corresponds with the former extent of the Centralian Superbasin, which formed following rifting during the Neoproterozoic breakup of the supercontinent Rodinia at around $850 \mathrm{Ma}$ (see below).

Australia is underlain by mostly thick lithosphere, which, at around $200 \mathrm{~km}$, is about double the global continental average. This is important because the thickness controls a continent's tectonics and seismicity, basin evolution, resource accumulation, topography, and landscape. The lithosphere appears to be thick beneath the Yilgarn Craton (Figure 2.18). The thickest lithosphere, however, occurs beneath the central Australian
Proterozoic mobile belts, which were tectonically active in the Paleozoic. The observation of thick lithosphere and relatively young orogenesis raises interesting questions regarding the age of the lithosphere (Paleozoic or younger) and the possible process or processes of its formation.

Thick subcontinental lithosphere is strong and difficult to melt, although it can be mechanically weakened by stretching, leading to basin formation. The way in which sedimentary basins evolve through time, from rifting to thermal subsidence, is strongly influenced by the thickness and structure of the lithosphere. Thick lithosphere conducts heat more slowly than thin lithosphere, so that the thermal sag sedimentation phase following rifting of thick lithosphere is delayed and prolonged. Australia's intracontinental basins are broad features that were filled over a prolonged interval from $850 \mathrm{Ma}$ to the Pliocene, with many basins overlying older basins (Figure 2.9).

The overall tectonic stability of much of Australia is also governed by the generally thick lithosphere. A consequence of this tectonic stability has been the preservation of ancient landscapes and the creation of the generally flat relief over most of the continent (Chapter 5). This lack of relief, however, has had a major impact on the development of rivers, which are generally sluggish and have low rates of discharge into the sea (Chapter 6). 


\section{Measuring Australia's record of 'deep' time}

Since the very beginning of geology as a science, obtaining a fix on geological, or 'deep', time has always been a goal for geoscientists. This knowledge allows for comparison and correlation, as well as estimates of the rates of geological processes. The earliest attempts were by palaeontologists, who recognised that fossil assemblages varied systematically through stratigraphic columns. Moreover, they were able to establish that these patterns varied systematically, in many cases, across the world. These fossil assemblages, through a discipline called 'biostratigraphy', could be used to establish relative ages of rocks (Chapter 3). The next challenge was to establish absolute ages.

The absolute age of Earth, and of rocks, is a quest that has interested humans-notably theologians and scientists-throughout time. One of the first estimates of the age of Earth was by Bishop Ussher, who in 1650 put it at 4004 BC (about 6000 years BP) based upon biblical records. Early naturalists and scientists also made estimates. In the latter part of the 18th century, Georges Buffon made one of the earliest estimates, at $c a 75 \mathrm{ka}$, based on the inferred cooling rates of Earth. In the middle of the 19th century, the age of Earth was thought to be of the order of a few hundred million years; Charles Darwin suggested $300 \mathrm{Myr}$ based on denudation rates, and William Thomson (later Lord Kelvin) gave a range of $10-400 \mathrm{Myr}$ based on thermodynamic considerations. It was not until the discovery of radioactivity in 1896 by Henri Becquerel, and the subsequent recognition that radioactive elements decayed at a constant, measurable rate, that geochronology as we understand it today began.

The discovery in 1913 of isotopes, followed by the persistence of Arthur Holmes, established radiometric dating, particularly using the $\mathrm{U}-\mathrm{Pb}$ system, as the best tool for determining the age of rocks and of Earth. Since then, a large number of radiogenic isotope systems- $\mathrm{U}-\mathrm{Pb}, \mathrm{C}, \mathrm{Rb}-\mathrm{Sr}, \mathrm{K}-$ $\mathrm{Ar}$ (including $\mathrm{Ar}-\mathrm{Ar}$ ), Sm-Nd, Hf-Lu, Re-Oshave been used as geological (and archaeological) chronometers. More importantly, the limitations of these systems have been established, and correlations of ages determined by independent systems have been established. Absolute ages determined radiometrically have also been used to calibrate relative age scales. For instance, radiometric 'gold spikes' have been used to anchor relative biostratigraphic ages and, occasionally, biostratigraphic assemblages can give more accurate and precise dates than radiogenic ones. Moreover, the radiometric ages have also been used to calibrate other geochronological techniques. Temporal variations in palaeomagnetic data, anchored by radiometric ages, have been used to provide accurate and precise ages of mineralising events, and variations in the stable isotope ratios of oxygen, hydrogen, sulfur and carbon can be used in certain cases to estimate the age of rocks and minerals that contain them.

Radiogenic (and stable) isotope ratios can also be used as tracers of geological processes. An example is variations in neodymium $(\mathrm{Nd})$ and lead $(\mathrm{Pb})$ isotope ratios that can indicate the juvenile or evolved character of crust and identify major crustal boundaries. Such boundaries are

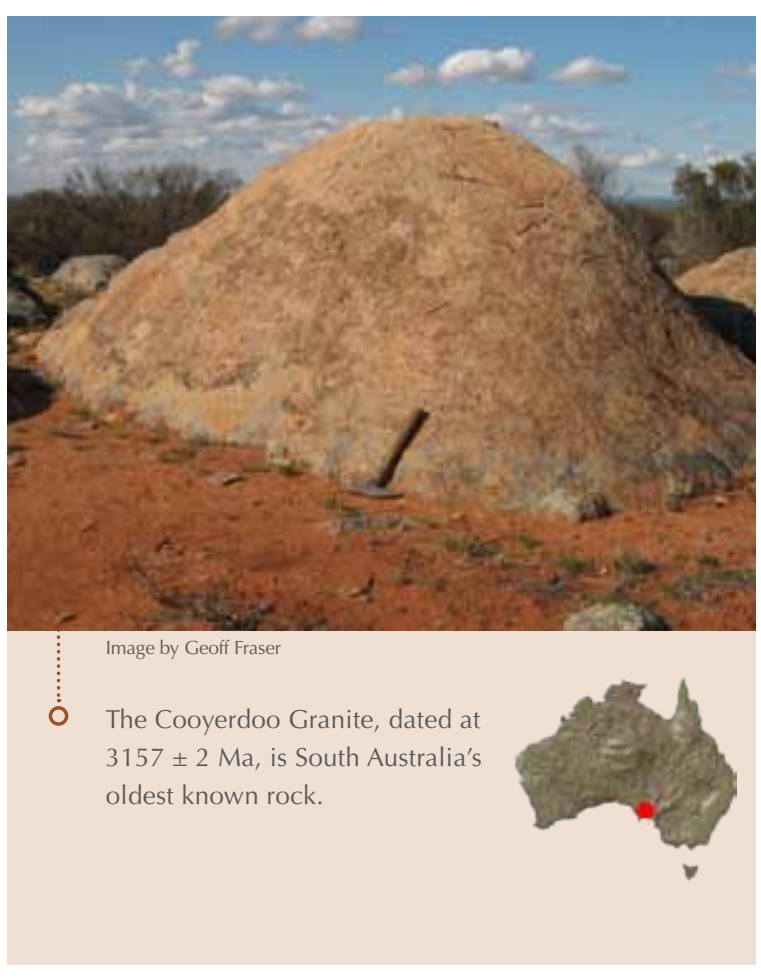


important controls on the distribution of ore deposits in Australia and elsewhere (Chapter 8). The $\mathrm{Ar}-\mathrm{Ar}$ technique is used to date metamorphic and mineralisation events (Box 8.2). The Re-Os isotopic system has also been used to date mineral deposits. Other techniques are deployed for younger rocks or investigating younger geological events, such as landscape evolution (Chapter 5) or coral growth (Chapter 6). They include fission-track, multiple isotopic systems, electron-spin resonance and various luminescence dating techniques.

Earth is now thought to be around $4540 \mathrm{Ma}$ old (Figure 2.19). Starting as a molten body that began to differentiate into layers according to elemental density and chemistry, the crust only began to develop around $150 \mathrm{Myr}$ later. Evidence for the world's oldest continental crust is preserved in the Jack Hills region (WA), which has metasedimentary rocks containing ca $4404 \mathrm{Ma}$ detrital zircons. The oldest known rocks on the Australian continent are the $3731 \pm 4$ Ma Meeribie Gneiss from the Murchison district (WA). The oldest rock within Australia's jurisdiction, however, is the Mt Sones Orthogneiss from the Napier Complex in Antarctica, which is dated at $3927 \pm 10 \mathrm{Ma}$. These old rocks were all dated using the $\mathrm{U}-\mathrm{Pb}$ isotopic system by the Sensitive High-Resolution Ion MicroProbe (SHRIMP), developed at The Australian National University (Box 2.4). The applications of SHRIMP have revolutionised the study of the old rocks of Australia and elsewhere, and SHRIMP has been used to date the oldest rocks in each state and territory (Table 2.2). One of the amazing features of SHRIMP, however, is its ability to accurately and precisely date the full spread of geological time (Figure 2.20).
Table 2.2: Age of oldest known rocks from each state and territory of Australia

\begin{tabular}{|c|c|c|c|c|}
\hline State/territory & Rock unit and location & Rock type & $\begin{array}{l}\text { Age (millions } \\
\text { of years) }\end{array}$ & $\begin{array}{l}\text { Geological time } \\
\text { (era) }\end{array}$ \\
\hline Australian Antarctic Territory & $\begin{array}{l}\text { Mt Sones Orthogneiss, } \\
\text { Enderby Land }\end{array}$ & Granodioritic gneiss & $3927 \pm 10$ & Eoarchean \\
\hline Western Australia & $\begin{array}{l}\text { Meeberrie Gneiss, } \\
\text { Murchison District }\end{array}$ & Gneiss & $3731 \pm 4$ & Eoarchean \\
\hline South Australia & $\begin{array}{l}\text { Cooyerdoo Granite, } \\
\text { Eyre Peninsula }\end{array}$ & Granite & $3157 \pm 2$ & Mesoarchean \\
\hline Northern Territory & $\begin{array}{l}\text { Woolner Granite, Pine Creek } \\
\text { Orogen (under Mesozoic } \\
\text { cover near Darwin) }\end{array}$ & Granite & $2674 \pm 3$ & Neoarchean \\
\hline Queensland & Yaringa Metamorphics, Mt Isa & Orthogneiss & $1874 \pm 4$ & Paleoproterzoic \\
\hline New South Wales & Redan Gneiss, Broken Hill & Gneiss & $1710 \pm 4$ & Paleoproterozic \\
\hline Tasmania & $\begin{array}{l}\text { Surprise Bay Formation, } \\
\text { King Island }\end{array}$ & Metasedimentary & ca 1300 & Mesoproterozoic \\
\hline Victoria & $\begin{array}{l}\text { Glenelg River } \\
\text { Metamorphic Complex } \\
\text { Ceres Gabbro }\end{array}$ & $\begin{array}{l}\text { Ultramafics-Serpentinite } \\
\text { Gabbro }\end{array}$ & $\begin{array}{l}\text { > ca } 520 \\
\text { ca } 600 ?\end{array}$ & $\begin{array}{l}\text { Early Cambrian } \\
\text { Neoproterozoic? }\end{array}$ \\
\hline Australian Capital Territory & $\begin{array}{l}\text { Adaminaby Group, } \\
\text { Brindabella Ranges }\end{array}$ & Metasedimentary & ca 470 & Ordovician \\
\hline Heard and McDonald Islands & $\begin{array}{l}\text { Limestone on Lauren's } \\
\text { Peninsula }\end{array}$ & $\begin{array}{l}\text { Limestone } \\
\text { Basalt? }\end{array}$ & $\begin{array}{l}\text { ca } 50 \\
\text { ca } 120 ? ?\end{array}$ & $\begin{array}{l}\text { Eocene } \\
\text { Cretaceous? }\end{array}$ \\
\hline Norfolk Island & Ball Bay Basalt & Basalt & са 3.2 & Pliocene \\
\hline Ashmore-Cartier Islands & Cartier Formation & Limestone & ca 30 & Oligocene \\
\hline Cocos (Keeling) Islands & Undated limestone & Limestone & ca $50 ?$ & $\begin{array}{l}\text { Eocene by correlation } \\
\text { with Christmas Island? }\end{array}$ \\
\hline Christmas Island & $\begin{array}{l}\text { Basalt, age greater than } \\
\text { Eocene sediments }\end{array}$ & Basalt & ca 60 & Paleogene? \\
\hline
\end{tabular}



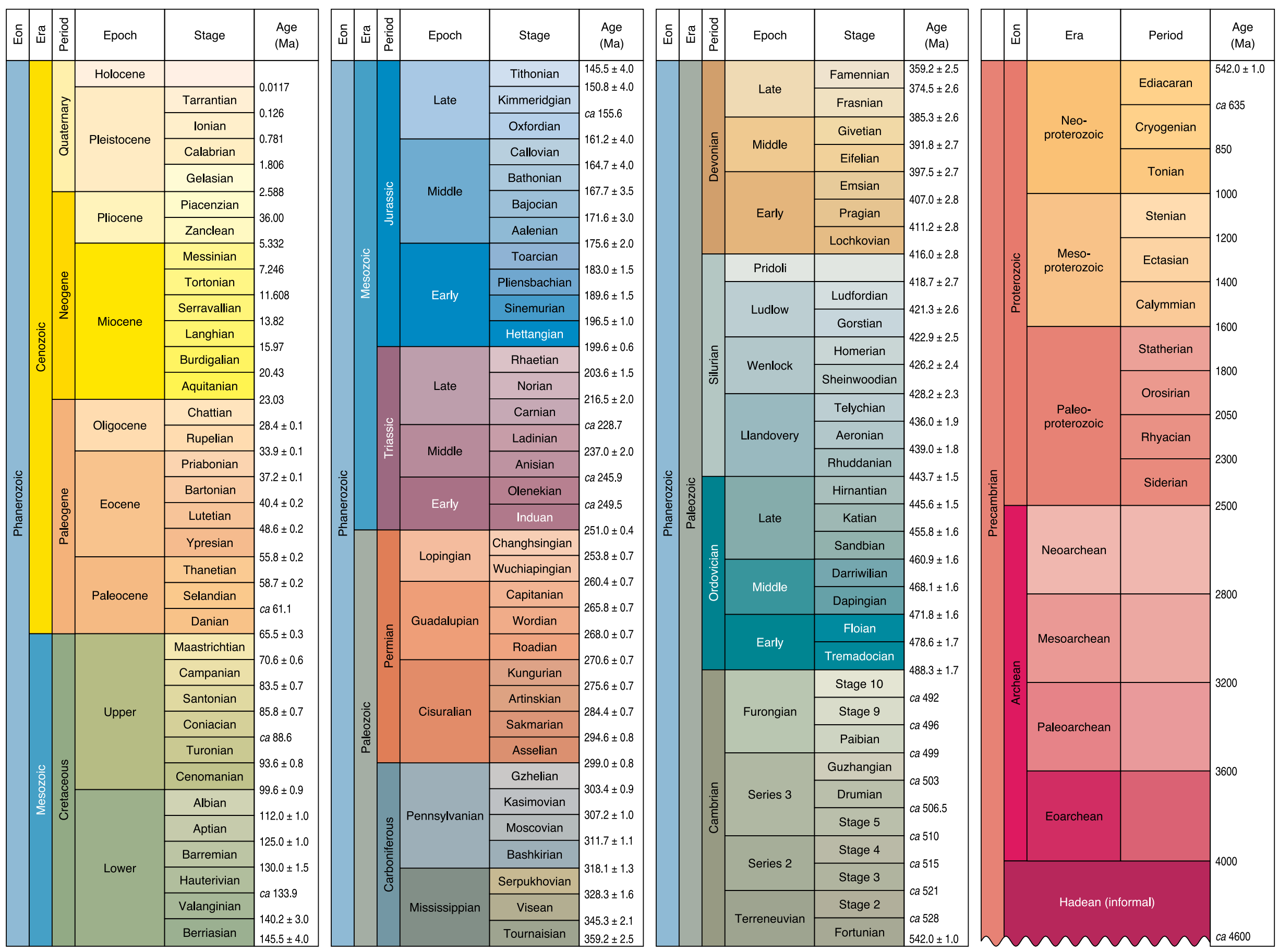

Figure 2.19: Geological time-scale modified from 2009 International Stratigraphic Chart (IUGS International Commission on Stratigraphy). 


\section{. SHRIMP - AUSSIE INGENUITY (вох 2.4)}

The Sensitive High-Resolution Ion MicroProbe, or SHRIMP, designed and built by The Australian National University, measures the age of rocks by analysing the isotopic ratios of daughter products from the natural decay of radioactive minerals. The most commonly used mineral for ancient rocks is zircon (zirconium silicate, $\mathrm{ZrSiO}_{4}$ ), which is a relatively stable mineral that is common in felsic igneous rocks and provides a natural radioactive clock due to its relatively high $U$ content.

Zircons can preserve a long geological history. For example, a zircon extracted from a particular granite may have:

- an old core, which is a relic of the source rock that melted to form the granite, that is

- encased in younger magmatic zircon that crystallised with the granite melt, which is

- rimmed by even younger zircon, a consequence of post-magmatic metamorphism.

Zircon is also resistant to weathering, so it is a common detrital mineral in sediments.

The zircon crystals are extracted from rock samples with careful crushing and mineral separation. Target zircons are then placed on a mount alongside a standard zircon, such as the Temora standard. A $30 \mu \mathrm{m}$ beam of ionised $\mathrm{O}_{2}$ is focused onto a spot within a single zircon grain to blast off atoms, which are collected and measured. This process allows individual sites of the crystal to be dated and the full history of the rock to be determined. The $\mathrm{U}-\mathrm{Pb}$ isotopic system is well understood. Uranium decays to $\mathrm{Pb}$, and it is the ratio of the isotopes of $\mathrm{U}$ and $\mathrm{Pb}$ that is measured by the mass spectrometer and used to calculate the age.
Other minerals can be dated with SHRIMP using the $\mathrm{U}-\mathrm{Pb}$ isotopic system. These include monazite, apatite, baddelyite, titanite and allanite, as well as carbonates. SHRIMP can also analyse stable isotope ratios, including those of $\mathrm{S}, \mathrm{C}, \mathrm{O}$ and $\mathrm{B}$, which provide information about scores and processes affecting these elements and can indirectly provide age data.

Today, SHRIMP machines are built in Canberra and operate in nine countries across five continents.
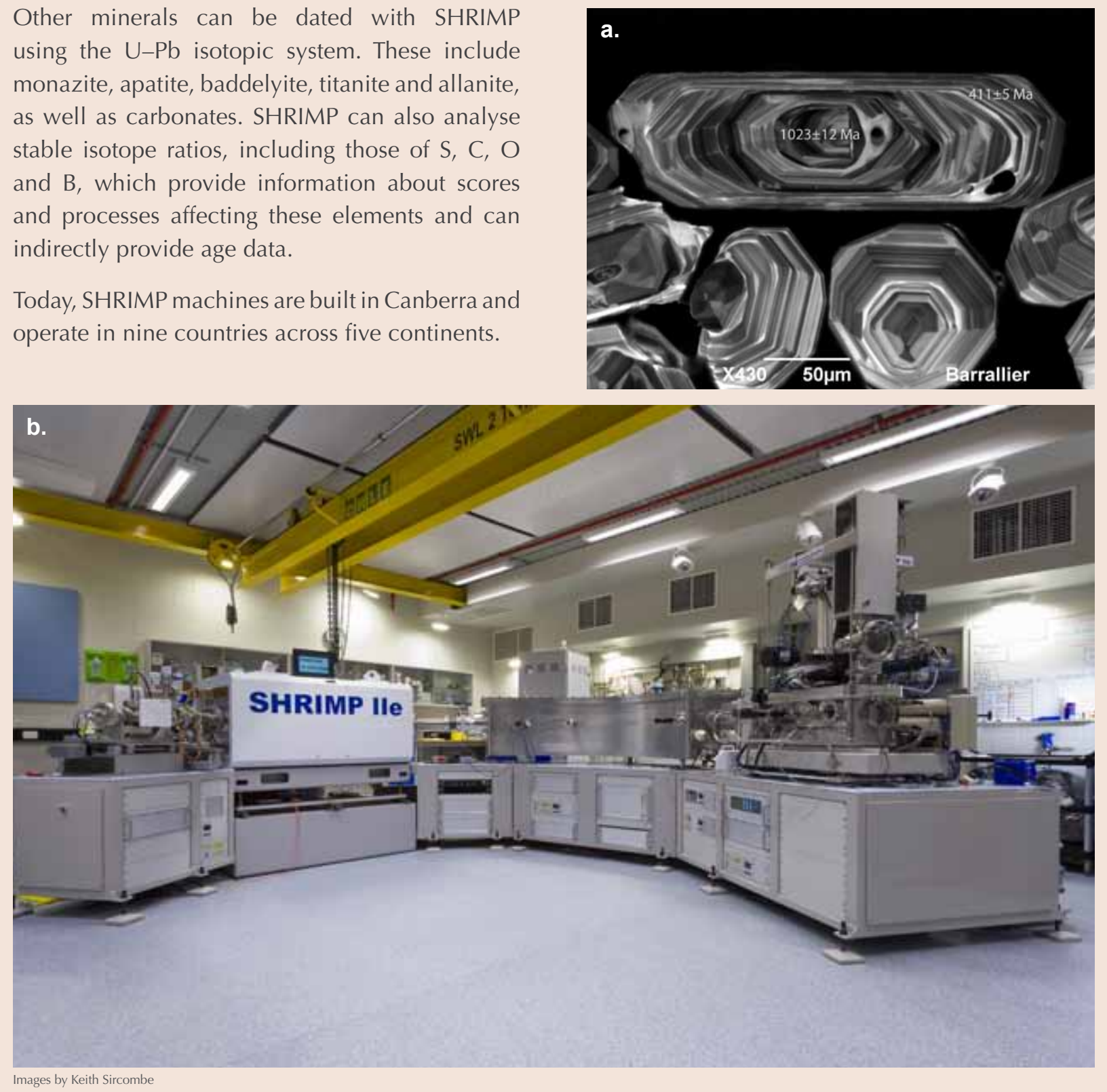

(a) Different regions of a zircon can be dated, telling us about the evolution of a particular rock. (b) Geoscience Australia's SHRIMP II dates around 150 rocks per year from regions of Australia. 


\section{Australia through time: a summary of the tectonic evolution}

Australia became the island continent $c a 34 \mathrm{Ma}$ when it finally broke from Antarctica. This was one of the last events in the breakup of Pangaea, the youngest of the world's supercontinents. Supercontinents form when most or all of Earth's continents amalgamate into one large landmass (Box 2.5). The make-up and even the existence of supercontinents through geological time has been the subject of much debate, with only the configuration of Pangaea generally agreed.

Although the existence and configuration of ancient supercontinents might seem to be a topic of debate only among academics, in truth, much of the geology and important mineral wealth, as well as the evolution of life in Australia, are the consequence of the amalgamation and breakup of supercontinents and smaller amalgamations (supercratons) through geological time-Vaalbara, Kenorland, Nuna (Columbia), Rodinia and Pangaea (including Gondwana) (Figure 2.20). Supercontinent history has not only controlled the distribution of many resources, but has surprising influences on geological processes that, in many ways, make Australia remarkable among the continents. With the important exception of Rodinia, peaks in the emplacement ages of igneous rocks closely correspond with periods of supercontinent assembly and breakup, in both Australia (Figure 2.20) and the rest of the world. This suggests that supercontinent processes involve extensive reworking of old continental crust and the formation of new continental crust.
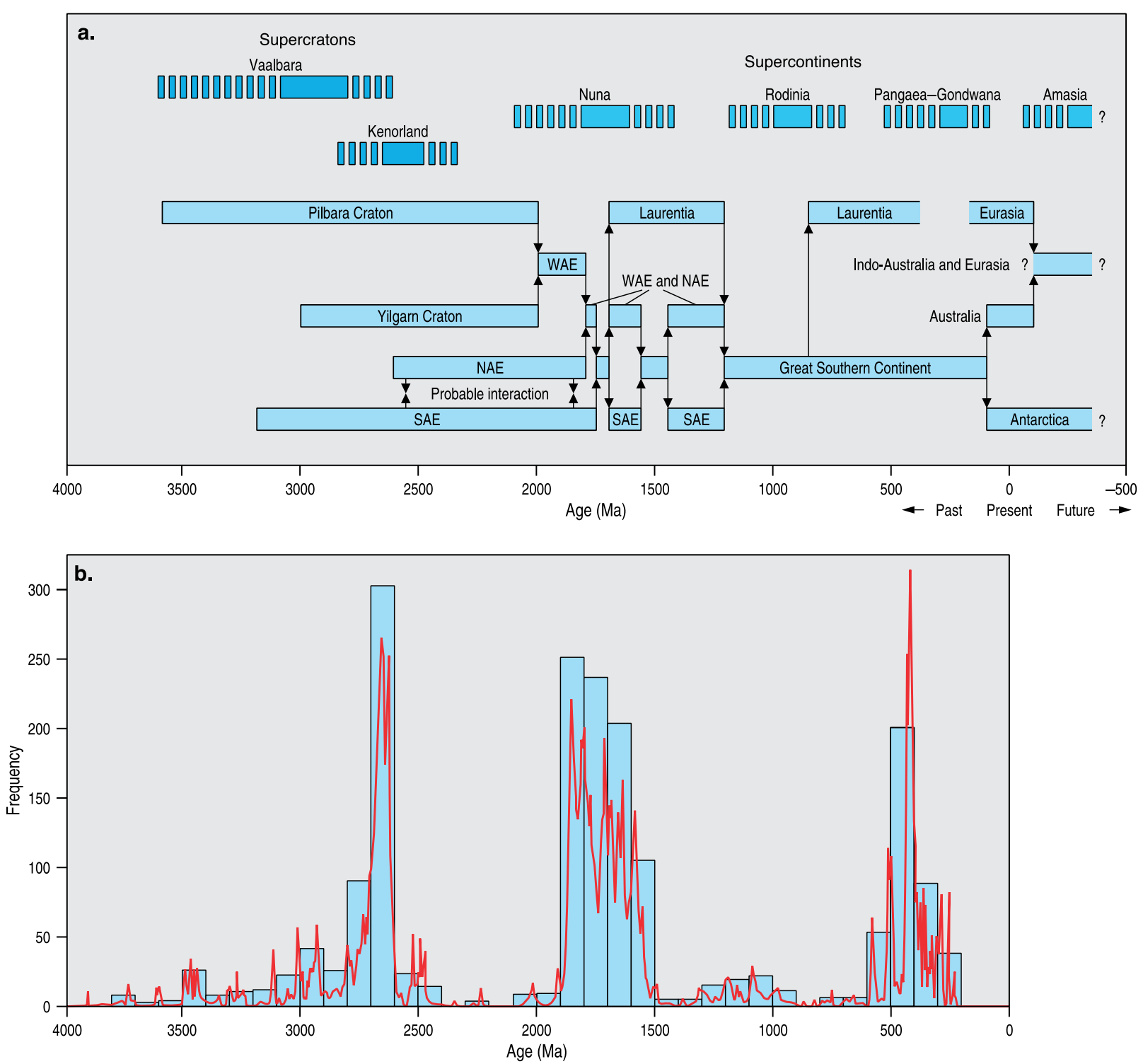

In simple terms, continental Australia grew from west to east. Archean rocks mostly occur in the west, Proterozoic rocks in the centre and Phanerozoic rocks in the east (Figure 2.8). The western two-thirds of the continent consist of three Precambrian elements: the West Australian, North Australian and South Australian elements,
Figure 2.20: (a) Assembly and breakup of the cratonic elements that constitute Australia from $4000 \mathrm{Ma}$ and their relationship to supercontinent cycles. (b) Histogram showing the distribution of the age of igneous rocks from Australia as determined using SHRIMP and other U-Pb analytical techniques. In (b), the blue bars are igneous rock ages binned in 100 Myr intervals, and the red line indicates the combined probability density distribution for the same igneous rocks. (Sources: Dr Keith Sircombe, Geoscience Australia and OZCHRON database)

$\mathrm{NAE}=$ North Australian Element: $\mathrm{SAE}=$ South Australian Element, WAE $=$ West Australian Element 


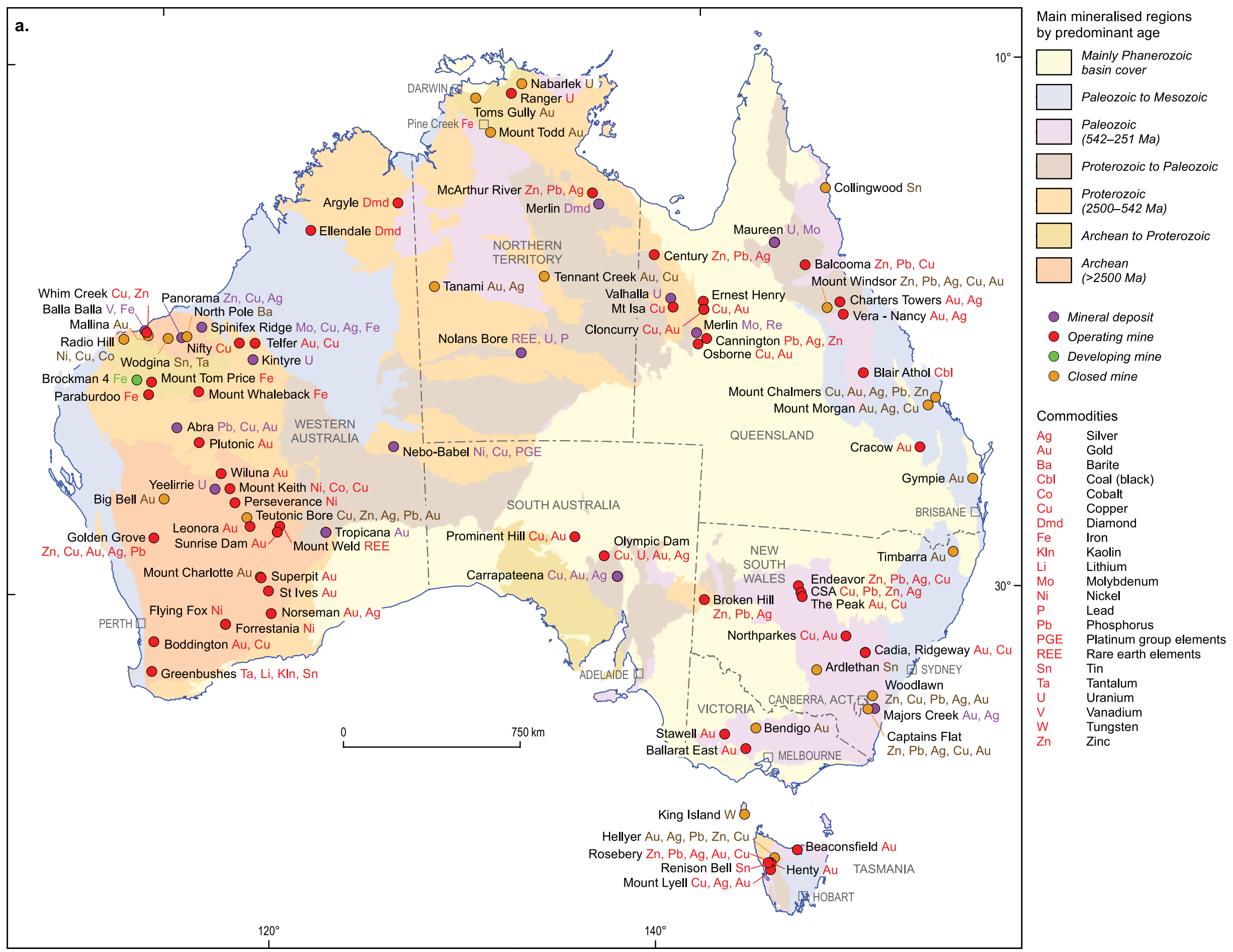

Figure 2.21: (a) Important mineral resources in 'hard rock' Australia. (b, opposite) Important mineral and energy resources in basins of Australia. 


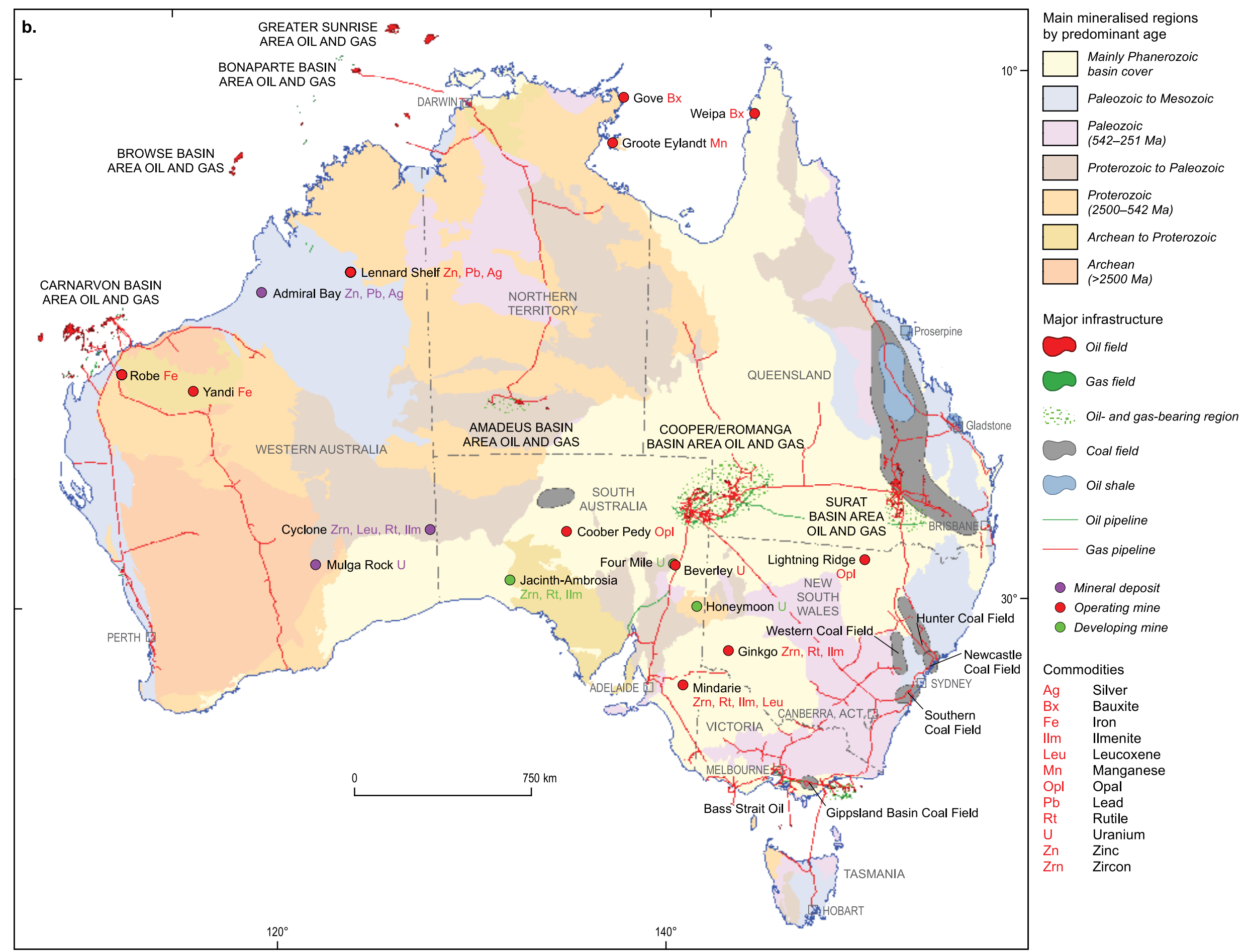


Supercontinents are amalgamations containing nearly all Earth's continental blocks. The concept for a geological entity originated with the coining of the term Gondwana by geologists in India in the late 1800s. First recognised from the late Paleozoic floral Glossopteris assemblage, found only in the southern landmasses of South America, Africa, Madagascar, India and Australia (and later Antarctica), this widespread distribution could only be explained at first if the countries were linked by now-absent 'land bridges' (Chapter 3). Since Alfred Wegener's 1912 continental drift hypothesis and work in the Southern Hemisphere, it has become apparent that continental blocks have amassed together and subsequently dispersed at several times in the Proterozoic and Paleozoic since their earliest formation. Supercontinent amalgamation commonly overlaps with dispersal, and thus the period of maximum packing of continental blocks defines the age span.

The interplay of continental blocks and mantle dynamics is fundamental to supercontinent formation and breakup, since it is likely that continents move away from locations of mantle upwelling and move towards downwelling mantle cells. Dispersion can occur through a number of mechanisms. There can be uplift and lateral stresses due to warming of the mantle beneath the supercontinent, since subduction is not able to cool the upper mantle within the interior of the large landmass. Alternatively, dispersion can be driven by thermal plumes linked to reorganisation of mantle flow. These two mechanisms may be linked.
Supercontinent formation and breakup have a significant influence on global climate because the grouping and location of continents affects wind patterns and ocean circulation. Eustatic sea-level is also affected; rapid seafloor spreading can decrease the volume of the ocean basins, as in the Eocene. This is because young oceanic crust is relatively buoyant and elevated compared with old oceanic crust (think of the mid-ocean ridges). There are also feedbacks between global tectonics, climate and sea-level. Times of continental amalgamation have been linked to major glacial accumulations ('icehouse' episodes, as in the end-Precambrian, end-Ordovician, end-Carboniferous) and hence lowered global sea-level. Dispersal of a supercontinent correlates with greenhouse regimes and flooded continents, as in the Silurian and mid-Cretaceous (Box 4.3).

The meridional distribution of continents in Pangaea in the Triassic induced an intense monsoonal system, and the seasonal aridity is recorded as red beds in many continents. The opening of circumpolar circulation can drive polar glaciation, such as in the Cenozoic rifting of Australia from Antarctica, and the opening of the Drake Passage, leading to the Antarctic ice sheets. Glaciation in the last 1-2 Myr in the Northern Hemisphere is also probably linked to the closure of equatorial circulation between the Pacific Ocean and the Caribbean Sea.

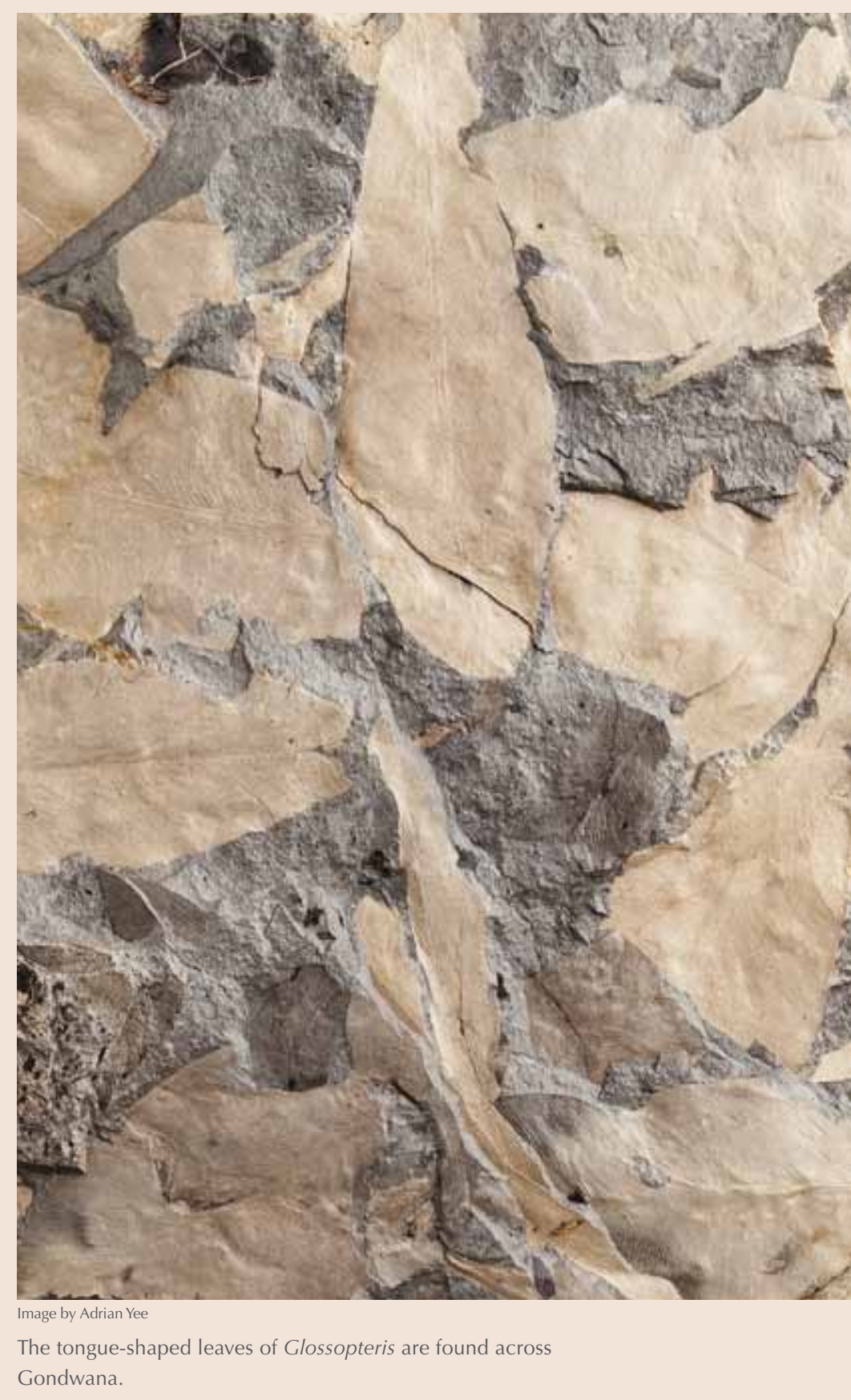


whereas the eastern third is made up mostly by the Paleozoic Tasman Element (Figure 2.10). The link between the spatial and temporal patterns is consistent with supercraton and supercontinent growth, particularly Kenorland, Nuna and Pangaea. The distribution of Australia's energy and mineral resources (Figure 2.21) is also governed by this broad pattern, with each of the four major cratonic elements characterised by distinctive deposit assemblages, both in time and in composition.

The Australian continent evolved in five broad but distinct time periods: 3800-2100 Ma, 2100-1300 Ma, 1300-700 Ma, 700-160 Ma and $160 \mathrm{Ma}$ to the present.

The first period saw the growth of nuclei about which cratonic elements grew, whereas the latter four periods involved the amalgamation and dispersal of Nuna, Rodinia and PangaeaGondwana, respectively. Below we present a history of the growth of the present-day Australian continent using this framework, noting that there is often significant uncertainty and disagreement about specific details. This 'geohistory' provides context for events that have shaped and changed Australia and Earth, including the evolution of life and changes in the composition of the atmosphere and hydrosphere.

As mineral deposits have been increasingly linked to geodynamic processes, the evolution of Australia's mineral and petroleum systems provides a parallel framework for the evolution of the continent as a whole. Appendix 8.1.1 provides a summary of the major mineral provinces through time.

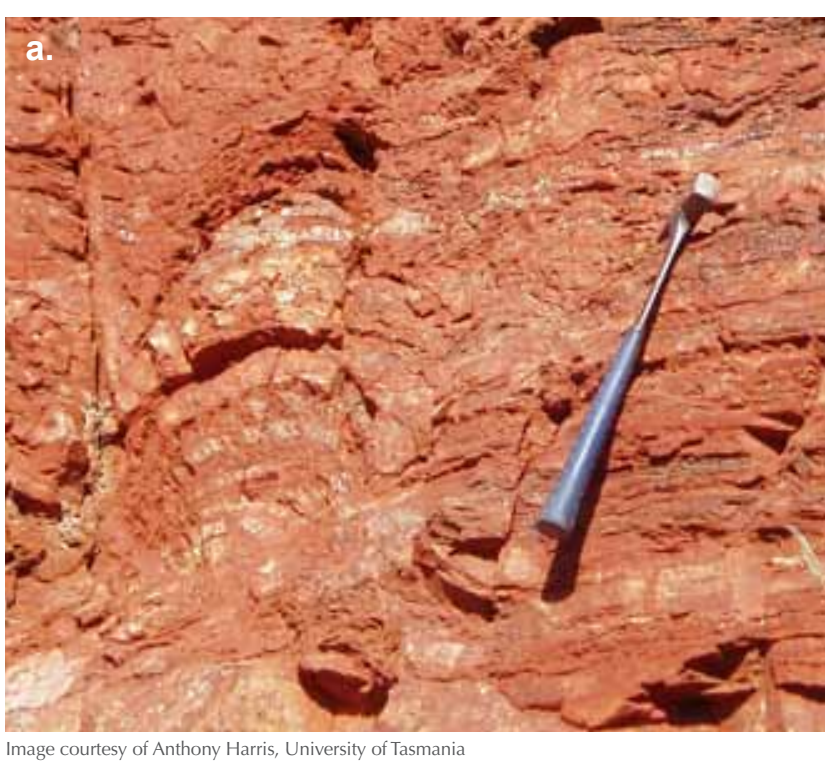

\section{0-2200 Ma-growth of cratonic nuclei}

The Narryer Terrane of the Yilgarn Craton contains both the oldest known rock in continental Australia and the oldest mineral known on Earth—3731 $\pm 4 \mathrm{Ma}$ and $c a 4404 \mathrm{Ma}$, respectively. The Jack Hills zircons are only about $150 \mathrm{Myr}$ younger than the age of Earth, and their study has important implications for the characteristics of the earliest period of Earth's history. The existence of zircons indicates that continental crust was formed very early. Oxygen isotope characteristics of these old zircons indicate that they crystallised from a magma that melted from a source that had previously interacted with seawater, telling us that both continents and oceans were present on Earth during the Hadean.

The Yilgarn and Pilbara cratons form the nuclei of the West Australian Element and are the most extensive exposures of old rocks in Australia. Over the past five years, old rocks have been increasingly

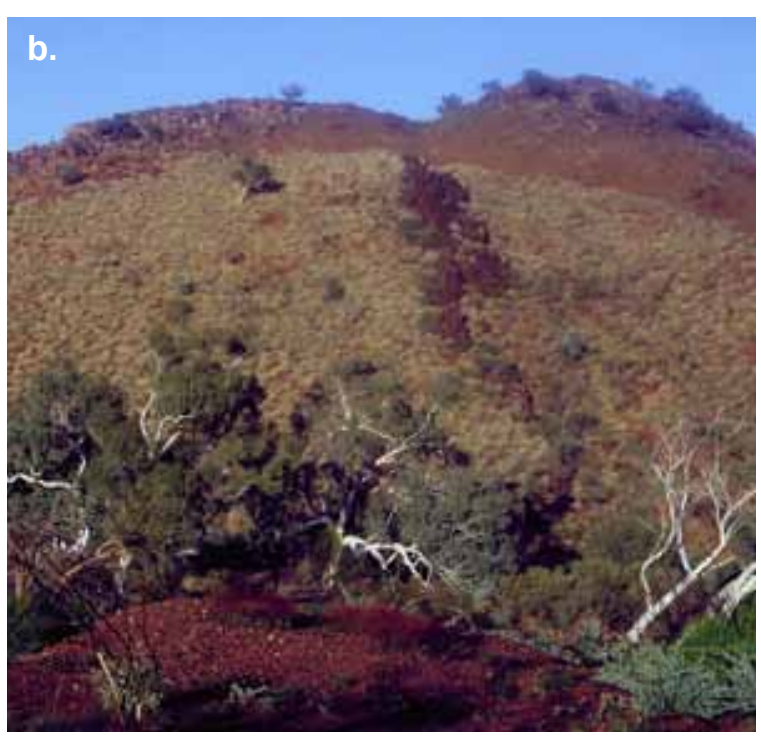

Figure 2.22: Photographs from the Pilbara Craton, Western Australia, showing (a) association between stromatolites and hydrothermal barite in the Dresser Formation, and (b) the Strelley Pool Formation angular unconformity. In (b), the unconformity is located at the base of the prominent outcrop along the ridgetop. The trend of the dark outcrop in the centre-right indicates the trend of bedding in the units below the unconformity. 


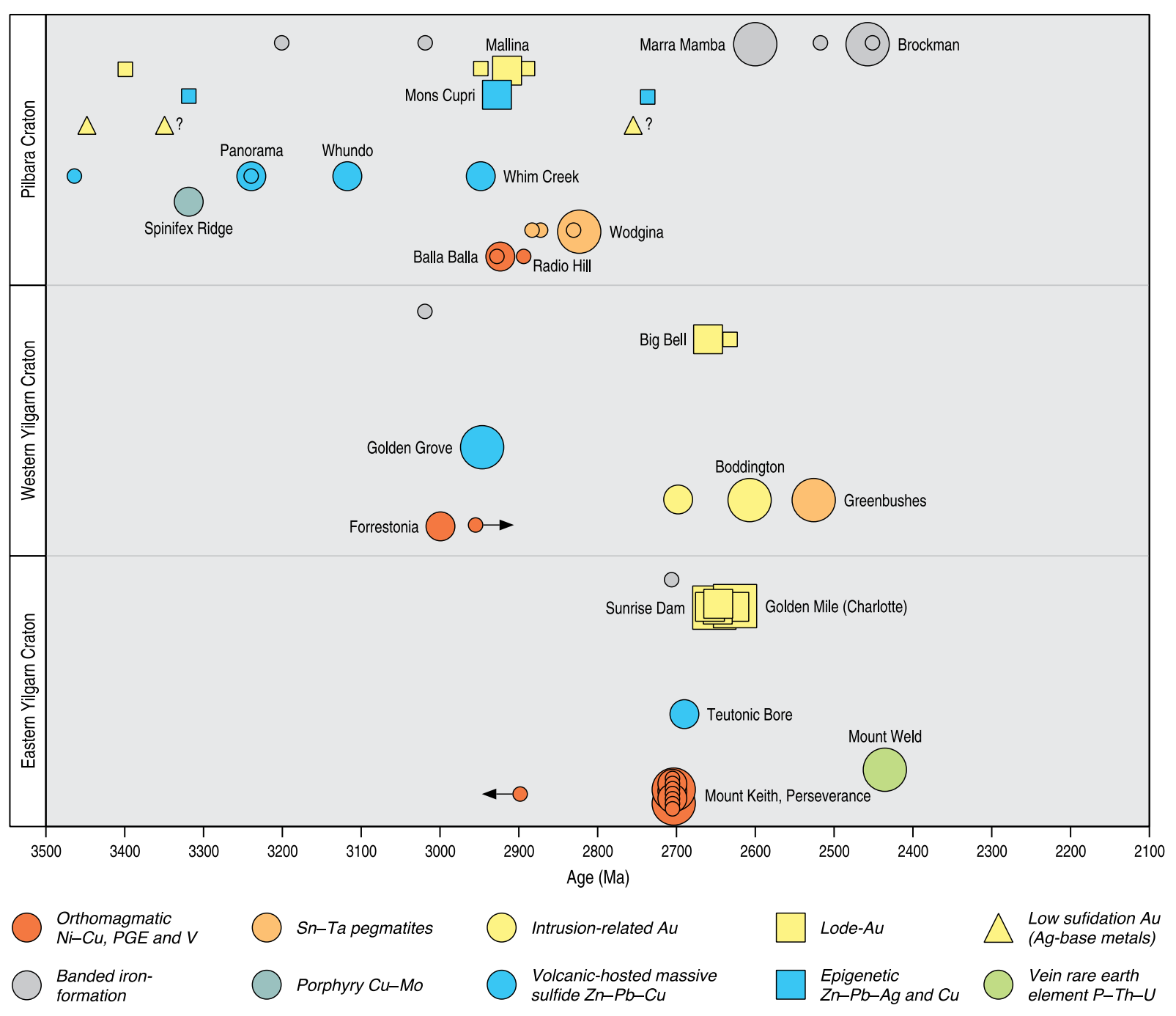

Figure 2.23: Major mineral deposits of Australia that formed between $3500 \mathrm{Ma}$ and $2100 \mathrm{Ma}$; see Figure 2.21 a for localities. Note that all deposits of this age occur in the West Australian Element. Symbol size broadly indicates deposit size relative to deposits with similar commodities. $\mathrm{PGE}=$ platinum group elements
The tectonic regime that formed the older units of the stratigraphy (>3200 Ma) has been a particular focus of scientific debate. Some people suggest that these old rocks developed within a thick oceanic plateau as the consequence of mantle plumes in a hotter early Earth, and that vertical tectonic processes were dominant (as opposed to plate tectonic processes). The rock types, their associations and the map patterns are certainly unlike anything we observe today. In younger units of the stratigraphy, such as the $c a 3120 \mathrm{Ma}$ Whundo greenstone belt in the western part of the Pilbara Craton, some of the oldest examples of modern plate tectonics are preserved. The volcanic and intrusive rocks of this region have distinctive rock associations and geochemical characteristics that are very similar to those found in modern arc environments. The Pilbara Craton also preserves the world's oldest unconformity (Figure 2.22b). This is dated at $c a 3430 \mathrm{Ma}$ and is marked by the Strelley Pool Formation, which is a regional chert overlying steeply dipping Warrawoona Group rocks.

The Pilbara Craton contains the oldest examples of many types of mineral deposits (Figure 2.23), including volcanic-hosted massive sulfide, lode gold, and epithermal and porphyry copper deposits. The Dresser Formation hosts the world's oldest ore deposit, sensu stricto, the North Pole barite deposit, which produced 129000 tonnes for use in drilling mud. These ancient mineral deposits share many features with geologically young and modern examples, indicating that many mineralising processes have persisted throughout most geological time. The oldest known hydrocarbons, within ore-related fluid inclusions, are associated 
with ca $3240 \mathrm{Ma}$ volcanic-hosted massive sulfide deposits in the Panorama district (Figure 2.23).

The Pilbara Craton also contains the oldest unequivocal evidence of life on Earth, preserved as stromatolites in the ca $3480 \mathrm{Ma}$ Dresser Formation (Chapter 3). Stromatolites grow today in the shallow, warm waters of Shark Bay, about $700 \mathrm{~km}$ to the southwest of their ancient 'ancestors' (Figure 3.2). Stromatolites are commonly closely associated with hydrothermal vents, as seen by their association with barite in the North Pole area (Figure 2.22a). These associations support the idea that life on Earth might initially have evolved in a hydrothermal environment.

The Pilbara Craton was probably a constituent of the oldest supercraton, Vaalbara (Figure 2.20a). This supercraton, which was made up of the Kaapvaal (southern Africa) and Pilbara cratons, began to form by $3600 \mathrm{Ma}$, and broke up at about 2800 Ma. Supercratons, which probably were smaller than most modern continents, were more long lived (Table 2.1, Box 2.5), possibly reflecting the stability of smaller cratonic blocks in an evolving Earth.

With the $c a 2800 \mathrm{Ma}$ breakup of Vaalbara, the Fortescue and Hamersley basins developed on the old crust of the Pilbara Craton, as some of Earth's earliest preserved examples of a passive-margin sequence. Thick mafic and felsic volcanic rocks, and sedimentary rocks dominate the basin fill, the most important being the banded iron-formations. These 2590-2450 Ma deposits (Figure 2.23) formed when reduced $\mathrm{Fe}^{2+}$-rich bottom waters were oxidised as they welled up onto the wide passive margin, depositing the iron. The vast majority of

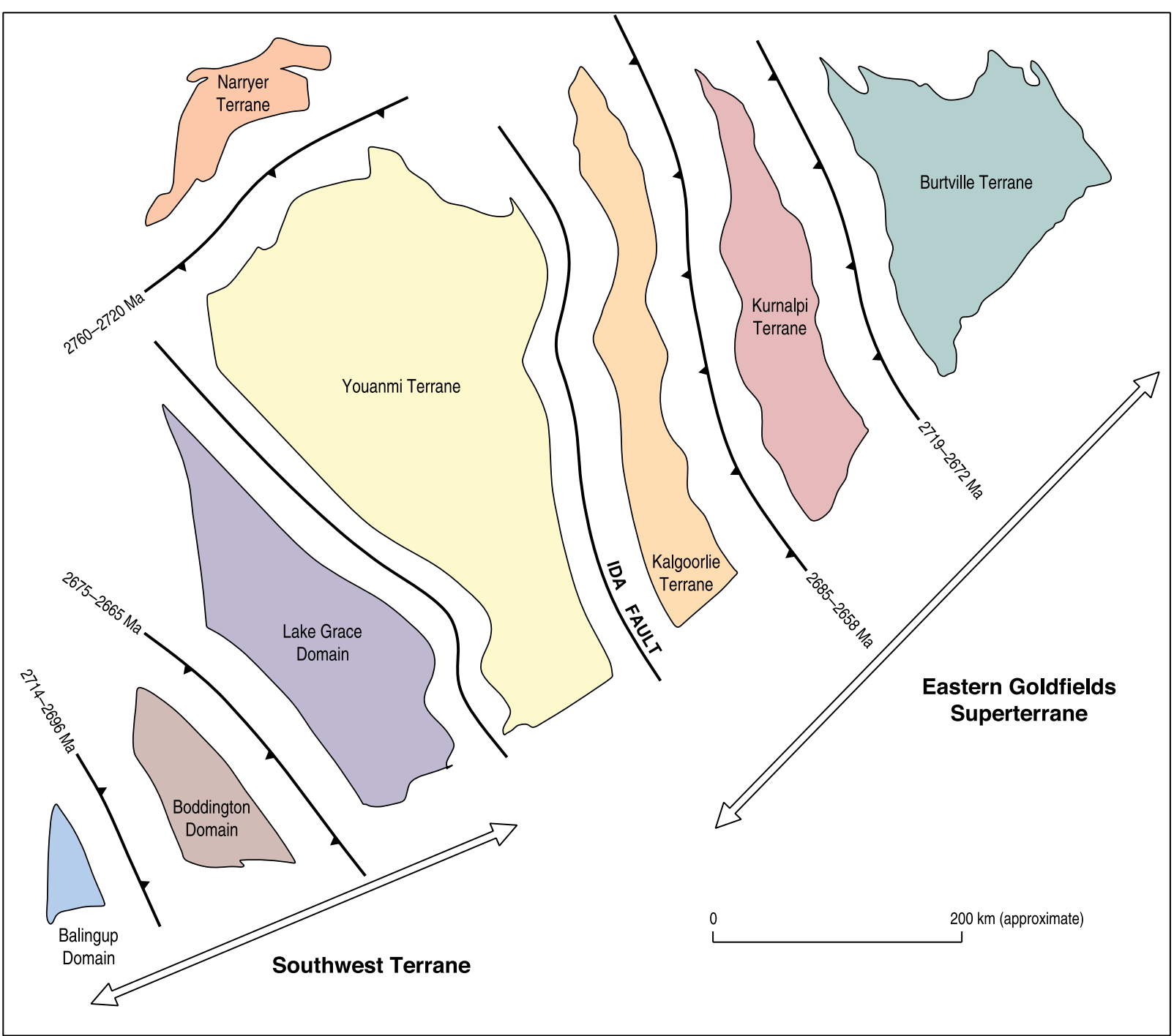

Australia's and the world's banded iron-formations were deposited between ca $2600 \mathrm{Ma}$ and $c a$ Figure 2.24: Neoarchean assembly of the terranes comprising the Yilgarn Craton of Western Australia. 

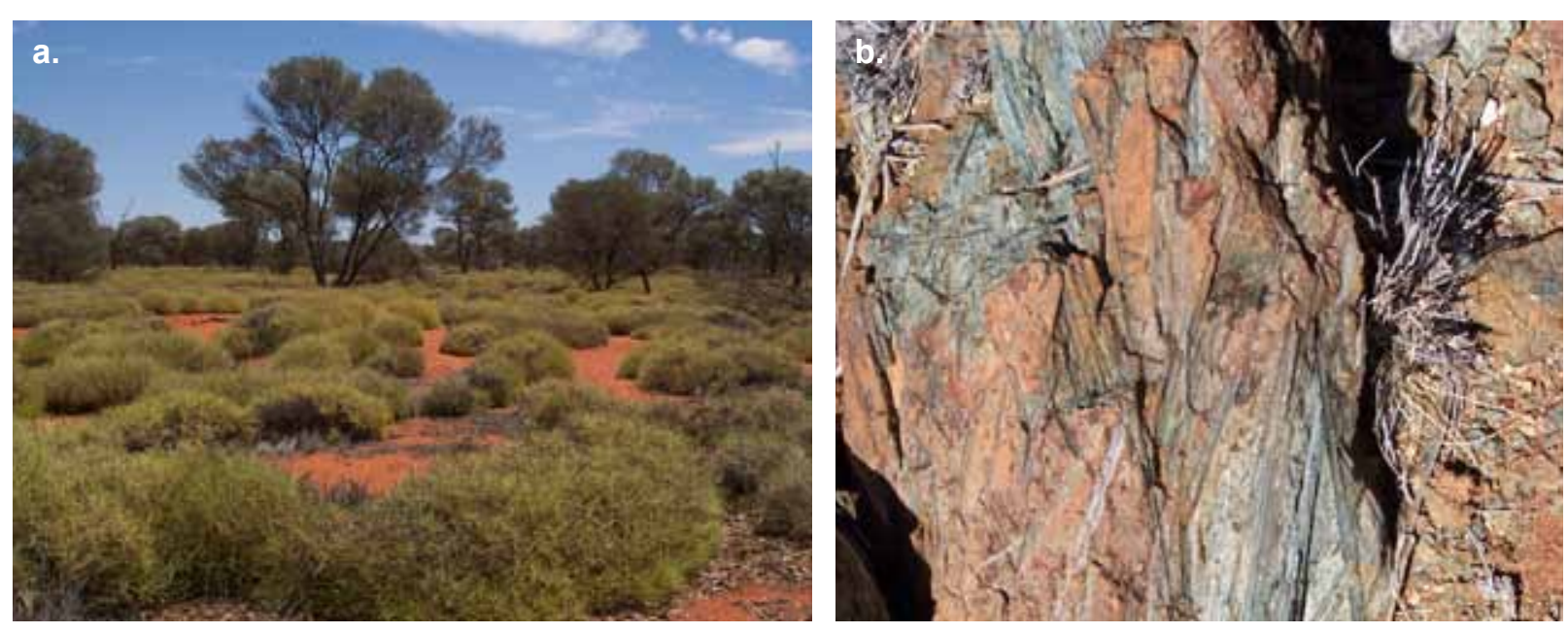

Figure 2.25: Photographs comparing (a) spinifex grass (Triodia) growing near Laverton with (b) spinifex-textured komatiite from a ca 2700 Ma ultramafic lava near Leonora, both in the Eastern Goldfields of Western Australia. The magnesium-rich lavas were erupted at high temperature, and the spinifex textures result from the cooling of olivine and pyroxene (crystals to $30 \mathrm{~cm}$ in this example). histories, the Yilgarn is characterised by the presence of short-duration, even catastrophic, crust-forming events. This is shown particularly well in Figure 2.20b, in which a short, sharp peak in the ages of igneous rocks corresponds to the final assembly of the Yilgarn Craton (and Kenorland) between $2720 \mathrm{Ma}$ and $2655 \mathrm{Ma}$. In contrast, the smaller Pilbara Craton is marked by several indistinct peaks over a $750 \mathrm{Myr}$ period (3500 Ma to $2850 \mathrm{Ma}$ ), which likely reflects a slower rate of overall crustal growth.

The Yilgarn Craton is older in the west than the east. The Narryer, Youanmi and Southwest terranes formed between $3730 \mathrm{Ma}$ and $2900 \mathrm{Ma}$ in the west; and the Kalgoorlie, Kurnalpi, Burtville and Yamarna terranes, which constitute the Eastern Goldfields Superterrane, formed between $2940 \mathrm{Ma}$ and $2660 \mathrm{Ma}$ in the east. Assembly of these terranes probably occurred through a series of east-dipping subduction zones that closed intervening basins between $2780 \mathrm{Ma}$ and $2655 \mathrm{Ma}$. The processes were probably broadly similar to modern subduction, with the formation of backarc basins and major orogenic events as fragments collided (Figure 2.24). These processes produced laterally continuous crust-penetrating shear zones that accessed the mantle, which was previously fertilised by subduction. These shear zones were important conduits for gold $(\mathrm{Au})$ mineralisation (Chapter 8), and may be one of the keys to the gold riches of the Eastern Goldfields Superterrane.

The Eastern Goldfields Superterrane is one of the two largest global Archean lode-Au provinces, with total resources of more than 8500 tonnes (Chapter 8). The discovery of Au changed the fortunes of Western Australia and encouraged mass migration of people in the 1890s (Chapter 1). The region is also a major nickel $(\mathrm{Ni})$ province. Individual deposits are hosted by komatiites, which are mantle-derived ultramafic volcanic rocks, a product of a hotter Archean Earth. Komatiites are also known for their 'spinifex' texture (Figure 2.25), which is caused by the quenched crystallisation of olivine and pyroxene minerals. The texture resembles needle-like 'spinifex' (Triodia), which is a characteristic grass that grows across more than $20 \%$ of the Australian continent (Chapter 3).

Like the Pilbara Craton, the Yilgarn Craton appears to have been a constituent of a supercraton-in this case, Kenorland-which likely included the Abitibi Subprovince in Canada (Figure 2.20a). These provinces formed over the same time period, share some isotopic similarities and are the two most richly mineralised Archean provinces known. Kenorland, which had amalgamated by ca $2660 \mathrm{Ma}$ and began to break up at $2480 \mathrm{Ma}$, is associated with different continental fragments 
from Vaalbara, suggesting the presence of two distinct, relatively long-lived supercratons in the Archean.

The recent identification of $c a 3150$ Ma granites in the South Australian Element extends its geological history by about 600 Myr. Recent dating has greatly increased the extent of known Archean rocks in the North Australian Element (Table 2.2). Taken together, these new data indicate a much more significant and prolonged Archean history in both the North and South Australian elements-a history that will become clearer as more data are collected.

\section{0-1300 Ma-amalgamation and breakup of Nuna}

The Paleo- to Mesoproterozoic evolution of the Australian continent is controversial. There are a number of tectonic models that fall into two broad groups: 'fixist' models that suggest there was relatively little lateral movement between crustal blocks, and 'mobilist' models that suggest relatively large lateral movements between crustal blocks. Below we present a mobilist model that implies that the three major Precambrian elements of Australia were assembled in the Paleo- to Mesoproterozoic as the supercontinent Nuna was constructed. There is, however, still significant difference of opinion regarding the details of this assembly; references to alternative ideas are presented in the bibliography.

The Pilbara and Yilgarn cratons were amalgamated by a series of orogenies (Capricorn Orogen) from ca 2215 Ma to 1950 Ma to form the West Australian Element, which is one of the earliest building blocks of Nuna (Figures 2.20 and 2.26). Most of the North

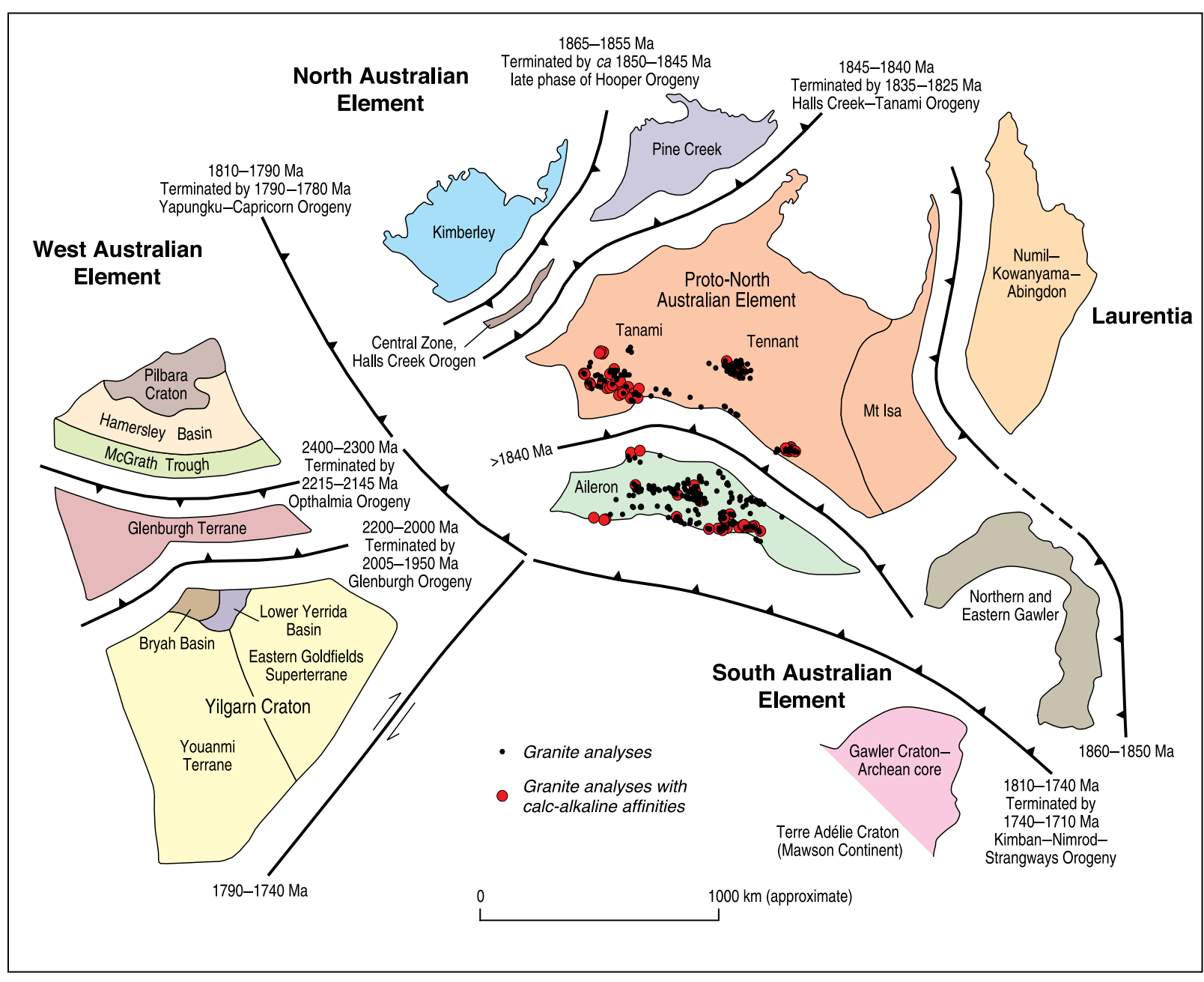

Australian Element formed before $1840 \mathrm{Ma}$ as a consequence of the amalgamation of the combined Tanami-Tennant-Mt Isa Province with the combined Kimberley-Pine Creek Province. The Aileron Province accreted from the south before $1840 \mathrm{Ma}$, and the Numil-Kowanyama-Abingdon seismic province accreted from the east before $1850 \mathrm{Ma}$ (Figures 2.20 and 2.26). Proto-Australia was probably linked with Laurentia—basically present-day North America— - to the east.
Figure 2.26: Assembly of proto-Australia. Proto-Australia consists of the three elements - the West, North and South Australian elements-which were assembled from smaller provinces in the mid-Paleoproterozoic. During the late Paleoproterozoic (ca $1810 \mathrm{Ma}$ ), these elements began to amalgamate, with final closure by ca 1740 Ma during the Kimban-Nimrod-Strangways Orogeny. It is likely that Laurentia was joined to proto-Australia on the east, and that the Terre Adélie Craton in Antarctica joined the Gawler Craton to the south. Parts of the North and South Australian elements may have been joined earlier (ca $2500 \mathrm{Ma}$ and ca $2020 \mathrm{Ma}$; Figure 2.20) as they show common histories at this time. However, the presence of abundant 1810-1760 Ma granites, many with calc-alkaline affinities (large red circles), along the southern margin of the North Australian Element, combined with the virtual lack of similar-aged magmatism in the South Australian Element, suggests that these elements were separated but likely converging at this time. Alternative interpretations can be found in the bibliography 

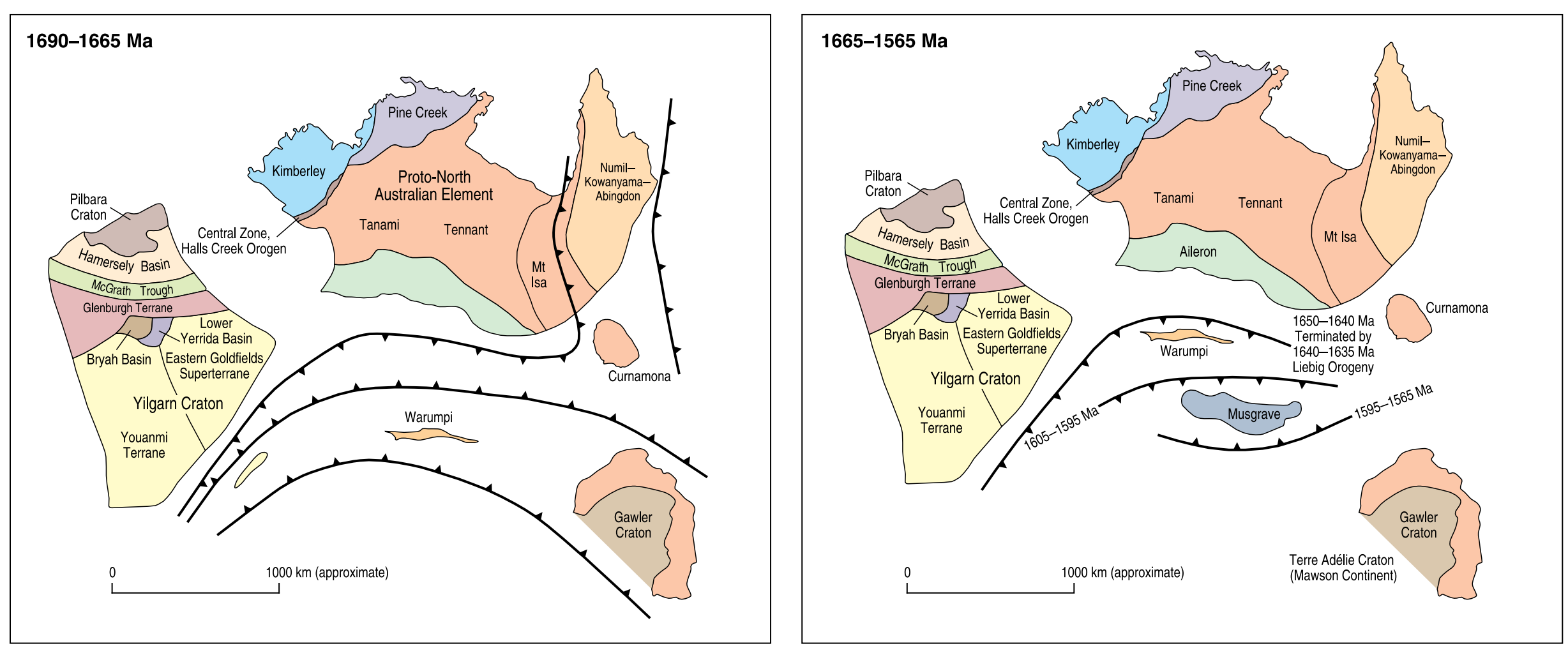

Figure 2.27: Diagram illustrating an interpretation of the evolution of proto-Australia from $1690 \mathrm{Ma}$ to $1565 \mathrm{Ma}$.

This involved extension along the eastern margin of proto-Australia and separation from Laurentia (1690-1665 Ma) and convergence along the southern margin of the combined North and West Australian elements (1665-1565 Ma).
The northern and eastern parts of Gawler Craton, which forms the core of the South Australian Element, grew, at least in part, as a consequence of subduction from the east, and may have originally been part of the North Australian Element (Figures 2.20 and 2.26). This interpretation is based on the provenance of sediments from the northern and eastern Gawler Craton, which matches the Mt Isa Province but not the older Archean core of the Gawler.

By about $1840 \mathrm{Ma}$, most of the West and North Australian elements, and large parts of the South Australian Element, had been assembled. Although the North and South Australian elements may have been together intermittently since ca $2500 \mathrm{Ma}$ (Figure 2.20), the period between $1810 \mathrm{Ma}$ and $1710 \mathrm{Ma}$ saw the assembly of the three Paleoproterozoic to Archean elements into the proto-Australian continent (Figure 2.26), which was one of the building blocks of Nuna. Initially, the North and West Australian elements amalgamated at 1790-1780 Ma during the Yapungku-Capricorn Orogeny, a union that has remained largely intact until today.

Beginning at about $1810 \mathrm{Ma}$, north- to northeast-directed subduction along the southern margin of the North Australian Element resulted in convergence between the North Australian and West Australian elements and the Archean core of the Gawler Craton. The West Australian Element was first to dock with the North Australian Element at $c a 1790 \mathrm{Ma}$ during the Yapungku- 
Capricorn Orogeny. After this collision, north-directed subduction continued underneath the eastern part of the North Australian Element, with a convergent margin along the southeast edge of the West Australian Element (Figure 2.26). This period of convergence concluded when the Archean core of the Gawler Craton (Figure 2.26) was accreted onto the combined North and West Australian elements during the Kimban-NimrodStrangways Orogeny at 1740-1710 Ma. During this time, the Gawler Craton probably joined to the Terre Adélie Craton to the south (now located in Antarctica).

Shortly thereafter, Nuna began to break up. This process, however, was complicated and involved not only divergence of Laurentia to the east, but development of a backarc basin system along the southern margin of Proterozoic Australia as subduction stepped to the south (Figure 2.27). The development of basins filled with turbidites and emplacement of tholeiitic mafic rocks along the eastern margins of the South Australian Element (forming the Curnamona Province) and the North Australian Element suggests divergence along the eastern margin of Proterozoic Australia beginning at about $1690 \mathrm{Ma}$ (Figure 2.27). During this period, or shortly thereafter, felsic magmatic rocks and minor sedimentary rocks (now ortho-and paragneisses) were emplaced and deposited to form the oldest known rocks in the Warumpi Province. In addition, convergence along the southeast margin of the West Australian Element resulted in the development of backarc basins between $1710 \mathrm{Ma}$ and $1665 \mathrm{Ma}$.

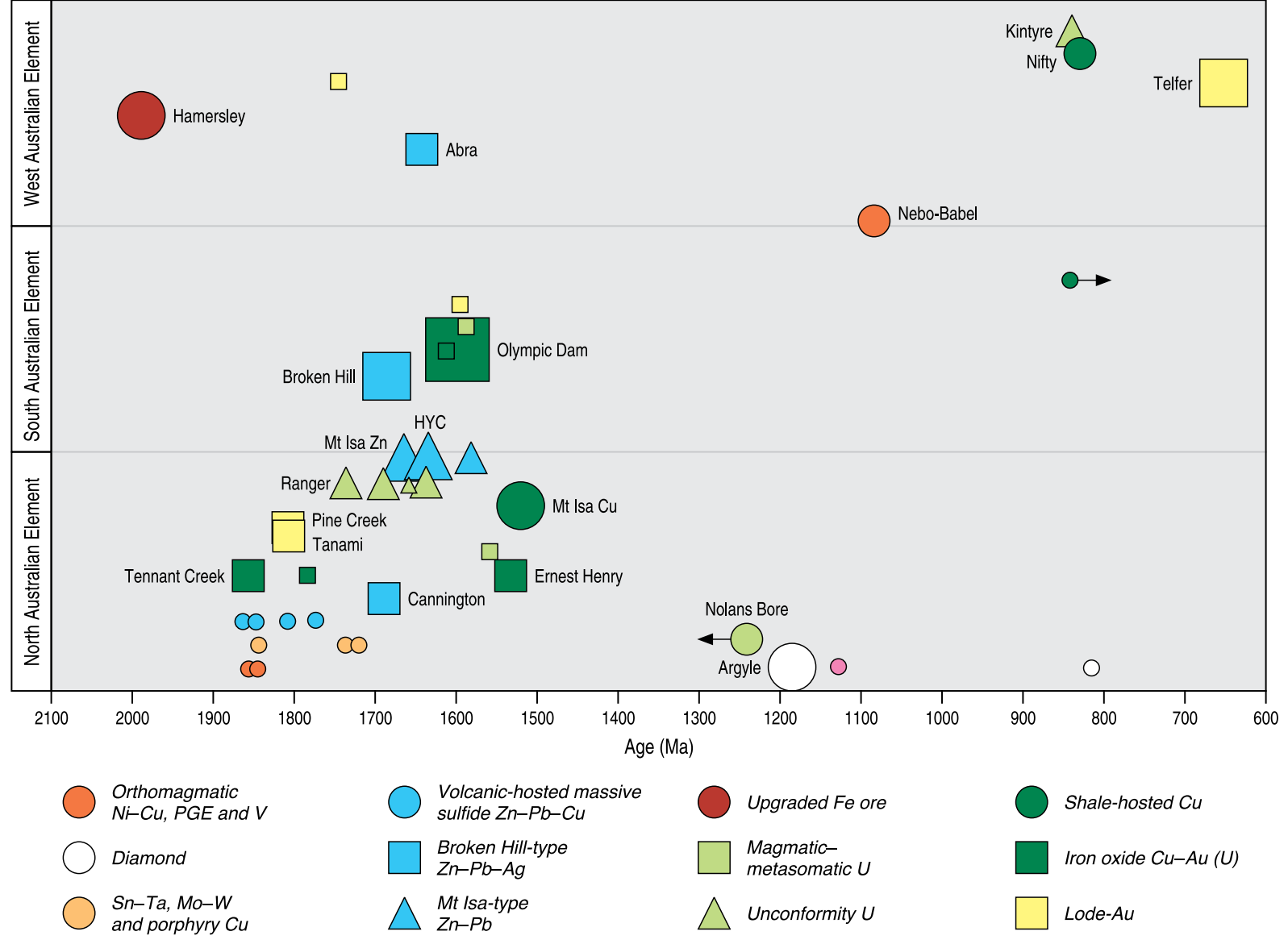

At about $1660 \mathrm{Ma}$, this backarc basin system began to close through a series of both south-and north-directed subduction systems. These initially accreted the Warumpi Province at ca $1640 \mathrm{Ma}$ during the Liebig Orogeny, followed by the Musgrave Province at $c a 1590 \mathrm{Ma}$, and the Gawler Craton at $c a 1560 \mathrm{Ma}$, to the North Australian Element. The Riversleigh inversion and the early phase of the Isan Orogeny in the Mt Isa Province may relate to accretion of the Warumpi and Musgrave provinces, respectively. At some time after the ca 1560 Ma event, the Mawson Continent (now in Antarctica), together with
Figure 2.28: Major mineral deposits of Australia that formed between 2200 and $700 \mathrm{Ma}$. Symbol size broadly indicates deposit size relative to deposits with similar commodities. See Figure 2.21 for localities.

$\mathrm{PGE}=$ platinum group elements 


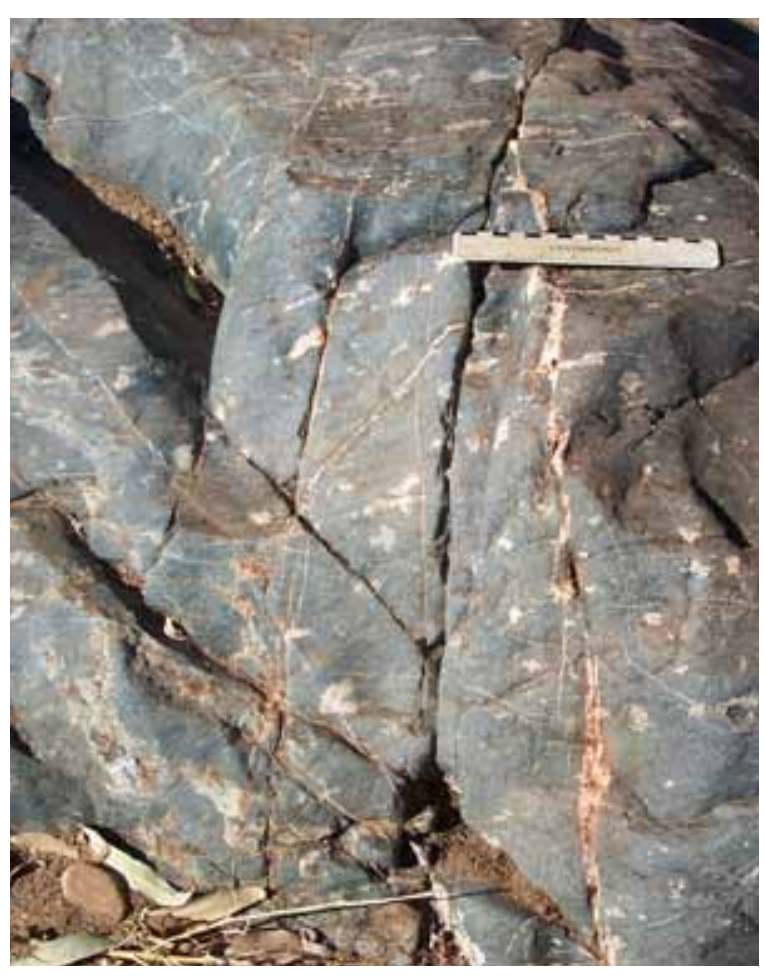

Figure 2.29: Cauliflower chert from ca 1650 Ma platform carbonates in the Mt Isa Province, Queensland. Cauliflower chert forms by the replacement of sulfate minerals during evaporation of seawater. These brines are important as they form mineralising fluids with a high capacity to carry metals (Chapter 8). the Gawler Craton, rifted from the combined West-North Australian Element, as these elements appear to have converged later during the assembly of Rodinia (see below). The extensive magmatic provinces comprising the 1595-1565 Ma Hiltaba Suite in the Gawler Craton and the $1545-1500 \mathrm{Ma}$ Williams Suite in the Mt Isa Province may be related to hotspot activity.

Much of Australia's mineral wealth, particularly iron ore and base metals, formed during the amalgamation and breakup of the Nuna Supercontinent (Figure 2.28). Iron ore deposits in the Hamersley Basin were upgraded (Chapter 9), and lode-Au deposits of the Pine Creek-Tanami formed, during amalgamation (Figure 2.26). In contrast, zinc $(\mathrm{Zn})$-lead $(\mathrm{Pb})$-silver $(\mathrm{Ag})$ deposits of the Australian Proterozoic $\mathrm{Zn}$ belt formed during breakup, and deposits of the Olympic Dam and Cloncurry mineral provinces may be related to hotspot activity (Chapter 8). The Mesoproterozoic was also a time of abundant high heat-producing granite and volcanic rock production. These rocks contribute to Australia's crustal heat production today, providing widespread potential for geothermal power or, in a few places, $U$ and possibly Th resources for fission reactors (Chapter 10). Another curiosity of this time is the development of the world's oldest oil play, although in uneconomic quantities, in the Upper Roper Group of the Mesoproterozoic Macarthur Basin, northwest of Mt Isa.

A major chemical change occurred in the oceans during the Proterozoic. The process of oxidation of the atmosphere, which began ca $2460 \mathrm{Ma}$, culminated in the oxidation of the oceans at
1900-1800 Ma. This had a number of important consequences. First, as the oxidised form of iron, $\mathrm{Fe}^{3+}$, is highly insoluble, the ocean waters were scrubbed of their iron, which resulted in a major period of banded iron-formation deposition during this time. Since this time, virtually no more banded iron-formations have been deposited, except during the Neoproterozoic icehouse period. Another consequence was an increase in oceanic sulfate concentrations, particularly in the upper part of the ocean, resulting in an increasing abundance of sulfate minerals, both evaporative (Figure 2.29) and hydrothermal, in the geological record.

The oxidation of the atmosphere had a dramatic effect on ore deposition in Australia and the rest of the world, a prime example being iron ore deposits. In the Hamersley Basin, giant iron ore deposits formed through the superposition of two geological systems (Figure 2.23). A 2590-2450 Ma sedimentary system deposited the original banded iron-formation during global anoxia, and then a ca $2000 \mathrm{Ma}$ hydrothermal system, related to convergence between the Pilbara Craton and the Glenberg Terrane (Figure 2.26), upgraded the banded iron-formation into iron ore. This upgrading event was one of the earliest consequences of the amalgamation of Nuna, as described above. Hamersley Basin iron ore is Australia’s largest export earner today (Chapter 9).

\section{0-700 Ma-amalgamation and breakup of Rodinia}

Compared with other periods of time, Australia was relatively quiescent between $1300 \mathrm{Ma}$ and $700 \mathrm{Ma}$, possibly because the landmass was largely in an intraplate setting during this time. Recent 


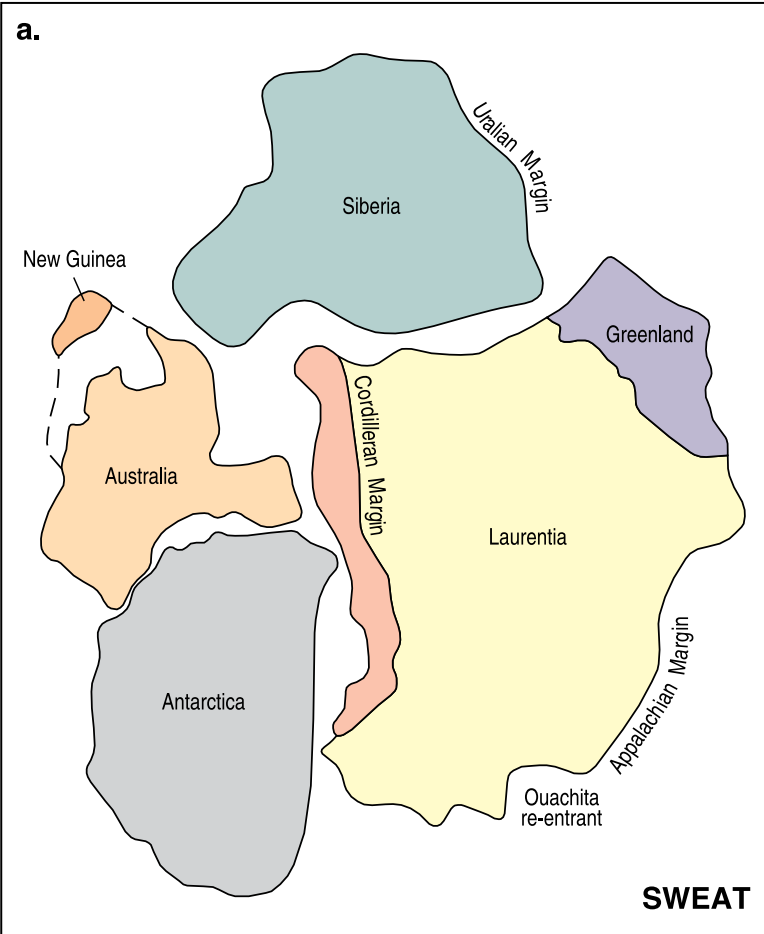

mineral discoveries and new geochronological data, however, highlight the tectonic activity of this period, which appears to have been associated with a different assemblage of mineral systems from those before. The supercontinent of Rodinia was assembled from $1300 \mathrm{Ma}$ to $900 \mathrm{Ma}$. Of the various reconstructions of Rodinia, most place eastern Australia (without the Tasman Element, which formed later) adjacent to Laurentia (Figure 2.30), with some placing North China in between.

During the time of Rodinian assembly, the West Australian Element was reworked by Meso- to Neoproterozoic orogenies along its northeastern (Paterson Orogen), southern (Albany-Fraser Orogen) and western (Pinjarra Orogen) margins. The Albany-Fraser Orogen and correlated deformation in the Musgrave Province mark the

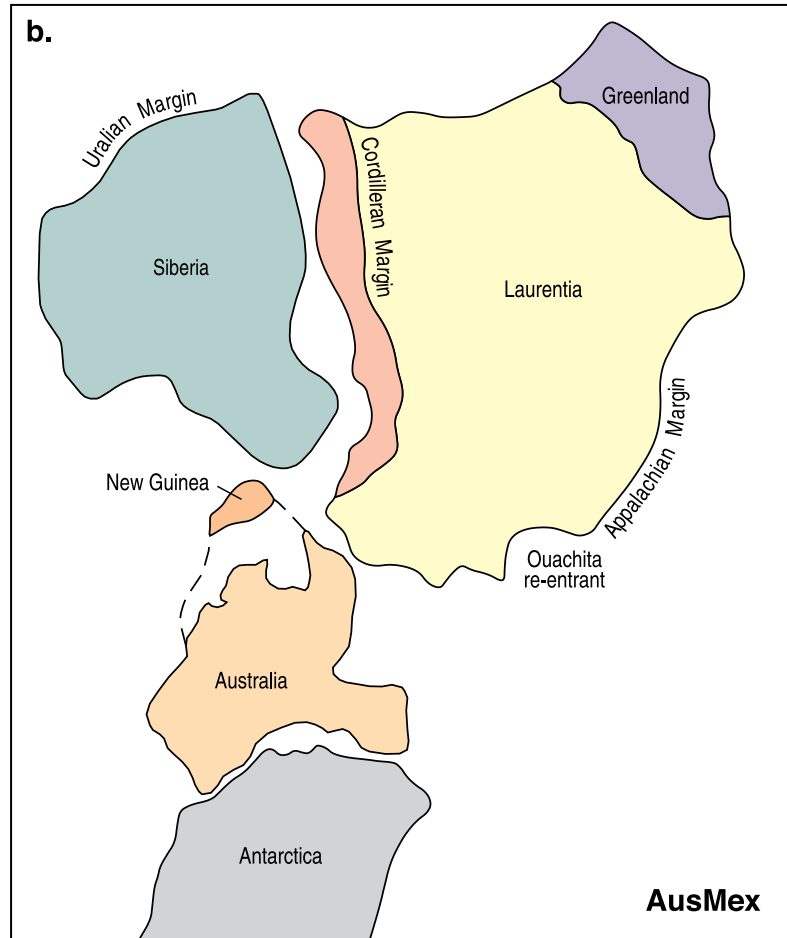

collision at $1345 \mathrm{Ma}$ to $1140 \mathrm{Ma}$ between the combined West-North Australian Element and the Mawson Craton. The Tropicana Au deposit lies along this margin (Figure 2.21a).

The earliest mineral deposits of this interval are a diverse suite, including diamond, rare earth elements and orthomagmatic $\mathrm{Ni}$-copper $(\mathrm{Cu})$ platinum (Pt) group elements (PGE) (Figure 2.28). All of these deposits are associated with alkalic rocks, including the $>1240 \mathrm{Ma}$ Nolans Bore rare earth element deposit and the $c a 1180$ Ma Argyle diamond pipe, which might have resulted from an intracratonic plume event. The abundance of base metal and Au deposits that characterise the assembly of earlier (Kenorland and Nuna) and later (Pangaea-Gondwana) supercontinents is missing, both in Australia and overseas. In central

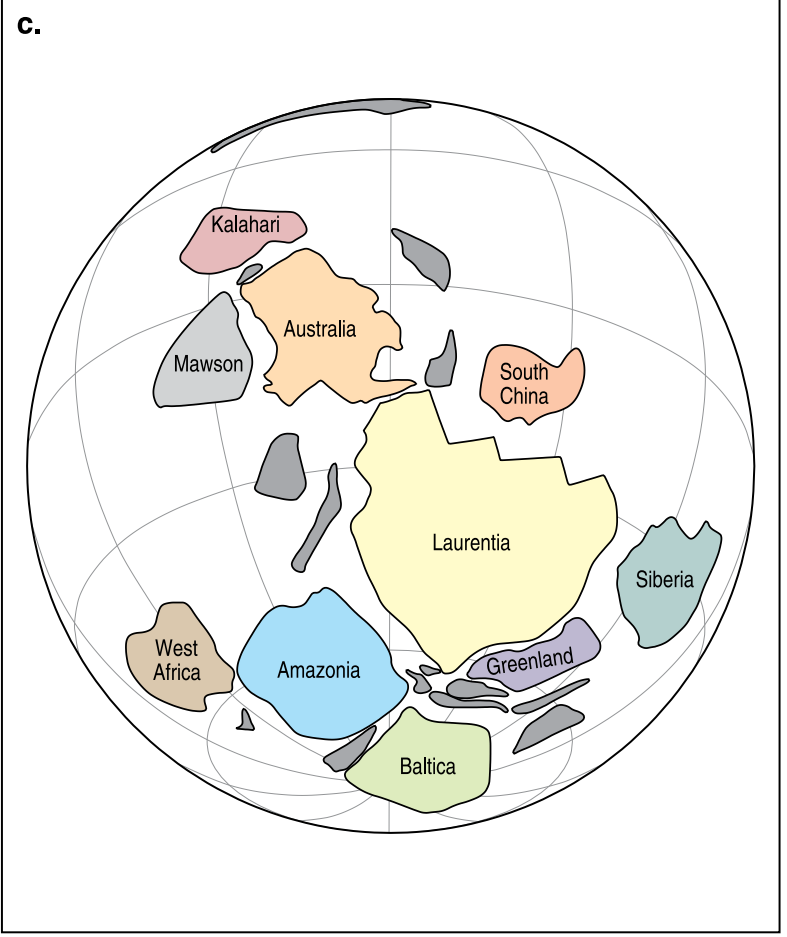

Figure 2.30: Alternative reconstructions of Rodinia. (a) The SWEAT (Southwest (US) - East Antarctic; Hoffman, 1991) reconstruction. (b) AusMex (Australia-Mexico; Wingate et al., 2002)

reconstruction. (c) Modified AusMex (Pisarevski et al., 2003) model. These are some of the many variants of the Rodinian reconstructions. 
o Getty Images IT Mead

Figure 2.31: Photograph of the MacDonnell Ranges, Northern Territory, showing the effect of geology on topography. Resistant rocks, such as the Heavitree Quartzite, form ridges, whereas softer rocks, such as the Bitter Springs Formation, form valleys. and western Australia, the Warrakuna Large Igneous Province crops out over $1.5 \mathrm{M} \mathrm{km}^{2}$, and was emplaced around $1075 \mathrm{Ma}$. It is associated with mafic-ultramafic intrusions such as the Giles Igneous Complex and associated $\mathrm{Ni}-\mathrm{Cu}-\mathrm{PGE}$ deposits such as Nebo-Babel (Figure 2.28).

The onset of rifting leading to breakup of Rodinia commenced $c a 850 \mathrm{Ma}$, leaving the jagged Tasman Line as the mark of the successful separation, probably, from Laurentia (Figures 2.10 and 2.30). One of the earliest manifestations of this breakup in Australia was the northwest-trending Gairdner Large Igneous Province (830 Ma), which was intruded into the South and North Australian elements and into the Paterson Orogen in the northwest. Extension associated with Rodinia breakup was likely to have been the immediate driver for the formation of the Centralian Superbasin. This basin system, which initiated at $c a 850 \mathrm{Ma}$, and continued to the
Devonian, affected most of central Australia and includes the Officer, Amadeus, Georgina and Yeneena basins (Figure 2.9). These basins include the earliest known major salt deposits, in the Bitter Springs Formation of the Amadeus Basin, several periods of glaciation, the first flowering of multicellular life and later the emergence of vertebrates (Chapter 3). The deposition of salt (and subsequent formation of salt deposits) has lowered the salinity of seawater by a factor of two or more since the Mesoproterozoic. Towards the bottom of these basins lie the Heavitree Quartzite and its correlatives. This quartzite makes up the spectacular red cliffs of the MacDonnell Ranges and Kings Canyon (NT), which are special places to the Aboriginal owners, and are famous as a tourist destination (Figure 2.31). Sandstone sheets like the Heavitree Quartzite are tens to hundreds of metres thick and extend for hundreds of kilometres laterally. They were only able to achieve 
this vast lateral extent because the Proterozoic land surface was not yet covered with vegetation (Chapter 3), so erosional rates were likely to have been enormous.

The global ice ages of the Neoproterozoic have left clear traces in a band across central Australia, from the Kimberley region (WA) to the Flinders Ranges (SA). Clear evidence of glacial dropstones can be found in the arid deserts of central Australia. Indeed, South Australian localities have given their names to these Sturtian and Marinoan glaciations (Figure 2.32). Over this long time span, the complexity of life increased and, towards the end of this period, the first clear fossils of multicellular life appeared. The type locality is in the Ediacaran Range slightly to the west of the Flinders Ranges (Chapter 3).

Uranium and $\mathrm{Cu}$ deposits in the Yeneena and the Adelaide basins formed between $840 \mathrm{Ma}$ and $790 \mathrm{Ma}$ (Figure 2.28); these deposits were related to basin formation and/or inversion. The revised AusMex reconstruction of Rodinia (Figure 2.30c) places Australia adjacent to the Kalahari Craton, which contains the highly productive Zambian Copper Belt. This belt is hosted by a basin of similar age and with similar fill to the Centralian Superbasin, and the ages of mineralisation overlap.

\section{0-250 Ma-amalgamation of Gondwana and Pangaea}

The Phanerozoic components of Australia were mostly assembled in a sequence of tectonic cycles, beginning with extension and ending in orogeny. To the west, the Pinjarra Element divides East Gondwana into Australo-Antarctic and Indo-Antarctic domains, which are distinct continental fragments with different Proterozoic histories that were juxtaposed by oblique collision at 550-500 Ma during the assembly of Gondwana.

Between $650 \mathrm{Ma}$ and $600 \mathrm{Ma}$, deformation was accompanied by granite emplacement and related $\mathrm{Cu}-\mathrm{Au}$ and tungsten (W) $-\mathrm{Cu}-\mathrm{Zn}$ mineralisation in the Paterson Province (Figure 2.33). The ca $550 \mathrm{Ma}$ Petermann Orogeny was a major intraplate event in central Australia. This event caused crustal thickening with around $20 \mathrm{~km}$ of vertical motion (eclogites are exposed today) and the formation of a large mountain belt with adjacent foreland basins, such as the Amadeus Basin. This mountain belt is part of a proposed 'Supermountain range' that may have stretched more than $8000 \mathrm{~km}$ through Gondwana, perhaps reaching Himalayan proportions. The weathering and erosion of this unvegetated mountain belt released a huge volume of sediment and nutrients (such as iron, phosphorus, strontium and calcium) into the marginal oceans and seas, possibly triggering the evolution of animal life (Chapter 3). In central Australia, the arksoic sandstone of the Uluru monolith (Ayers Rock) and the conglomerate of Kata Tjuta (the Olgas) formed in a foreland basin adjacent to this vast mountain range.

To the east, the Tasman Element was assembled successively onto the older Precambrian continental core to the west (Figure 2.34). These tectonic cycles produced Australia's most significant volcanic-hosted massive sulfide (VHMS), epithermal and porphyry $\mathrm{Cu}-\mathrm{Au}$

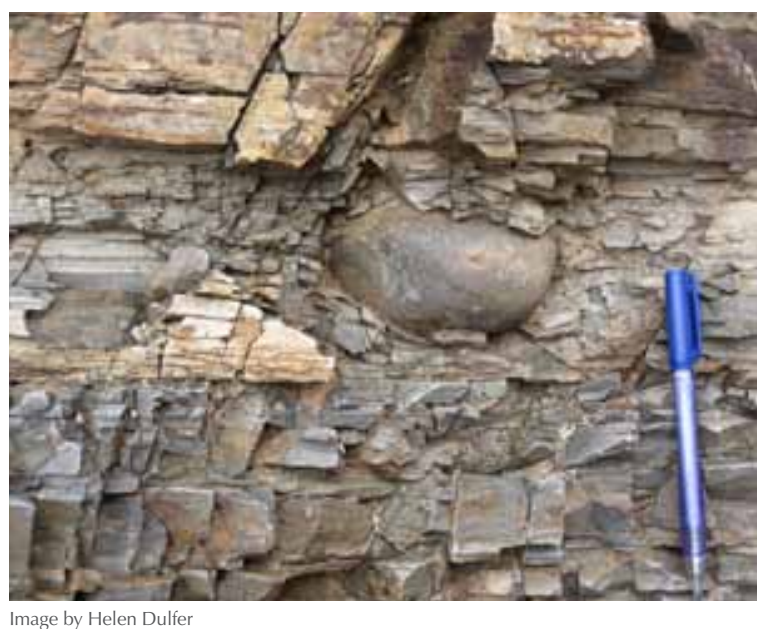

Figure 2.32: Dropstone in the Merinjina Tillite, Adelaide Rift Basin, South Australia. Dropstones form in shallow seas whe icebergs melt, dropping contained stones onto muds on the seafloor. This example is from the Sturtian glaciation, a record of so-called icehouse Earth, when much of Earth's land surface was affected by glaciers. 


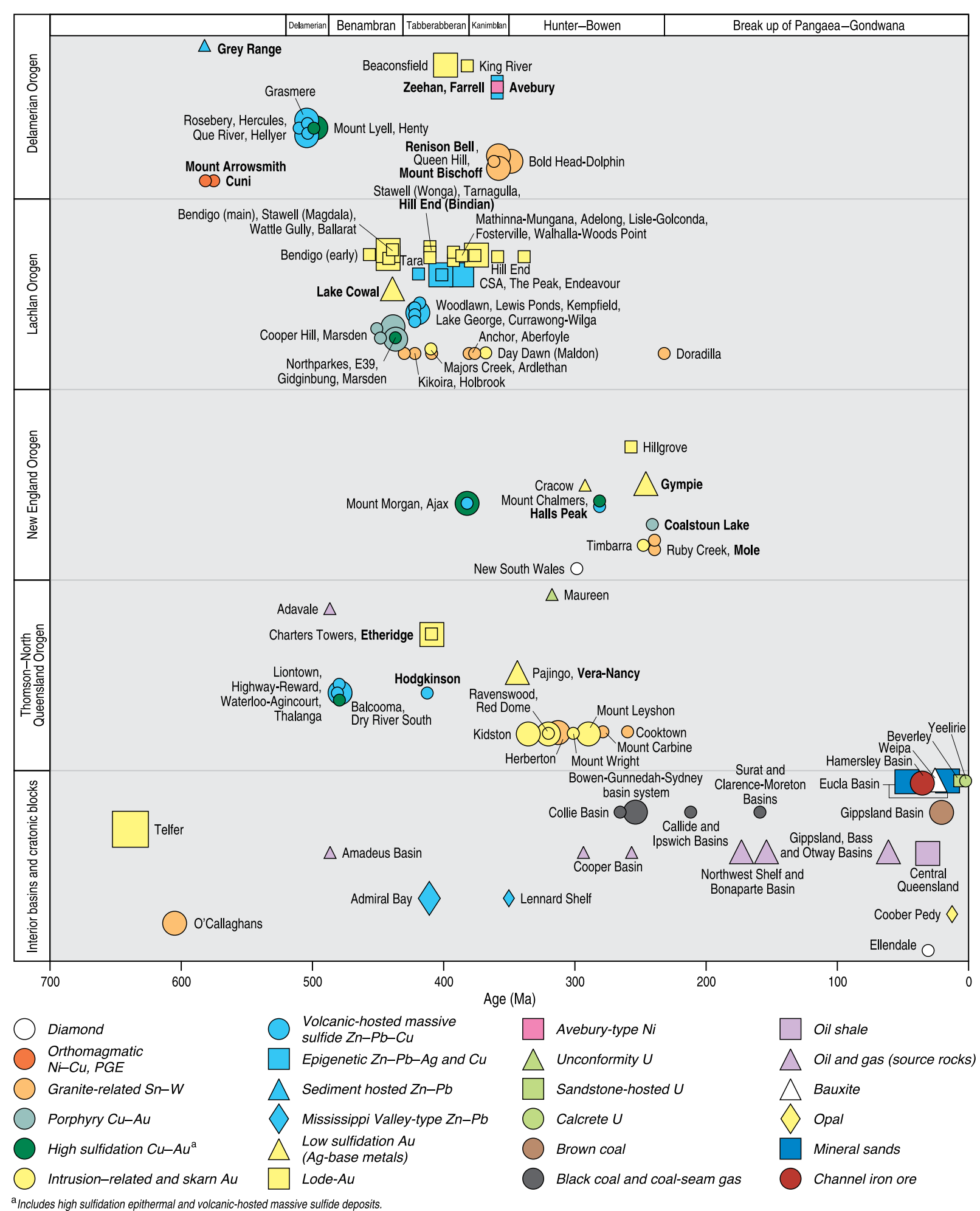

deposits, and major lode-Au and magmatic tin provinces (Figure 2.33 and Appendix 8.1.1). Central Australia underwent a series of intraplate extensional and contractional events, many being time equivalent to those in the east.

Following the breakup of Rodinia, a passive margin with local rifts formed on the eastern edge of Australia, which now faced the proto-Pacific Ocean (Figure 2.34). By $515 \mathrm{Ma}$, or even earlier (560 Ma), subduction started in southeastern Australia, which saw the crust/lithosphere of eastern Australia grow via a series of episodic tectonic cycles. These cycles lasted between $30 \mathrm{Myr}$ and $130 \mathrm{Myr}$, beginning with a period of extension associated with the formation of backarc basins, and terminating with contractional deformation events, when continental slivers and island arcs were accreted back onto the Australian continent (Figure 2.34). There were five such cycles: the Delamerian (515-490 Ma), Benambran (490-440 Ma), Tabberabberan (440-380 Ma; includes the Bindian), Kanimblan (380-350 Ma) and Hunter-Bowen (350-220 Ma). The younger cycles overprint the older cycles, but, in general, the cycles become younger to the east (Figure 2.34).

There is a general progression in the types of mineral deposits formed within individual cycles (Figure 2.33). Mineral deposits formed in arcs

Figure 2.33: Major mineral deposits of Australia formed during the period $650-0 \mathrm{Ma}$, in particular during the assembly and breakup of Pangaea-Gondwana. Symbol size broadly indicates deposit size relative to deposits with similar commodities.

See Figure 2.21 for localities.

$\mathrm{PGE}=$ platinum group elements 
(e.g. porphyry and epithermal deposits) and backarcs (e.g. volcanic-hosted massive sulfide deposits) form early in cycles, whereas mineral deposits formed mostly during contractional deformation (e.g. lode-Au and structurally hosted base metal deposits) came late in the cycle.

While accretion was occurring in the east, parts of Gondwana were being rifted from the northwest. The first of these rifting events may have been related to the emplacement of the Kalkarindji Large Igneous Province in Western Australia and the Northern Territory, which is known from basalts dated at $520 \mathrm{Ma}$. A progression of younger rifting events led to excision of a succession of slices off northwest Australia, with components now found in north China $(380 \mathrm{Ma})$, Sibumasu in South-East Asia ( ca $290 \mathrm{Ma})$, Lhasa in Tibet $(210 \mathrm{Ma})$ and Argo Land in Burma (162-154 Ma). From the Carboniferous, thick sedimentary successions accumulated in rift basins along the evolving northwest margin and in the Perth Basin (Chapter 4).

Activity related to convergence on the eastern seaboard also influenced the continent's interior. Interior events that link temporally to events in eastern Australia include development of the Larapintine Seaway and the Alice Springs Orogeny (which actually includes three separate orogenic events). The Larapintine Seaway is a concept that goes back to the 1930s, linking the

Figure 2.34: Schematic diagrams showing the tectonic evolution of Australia between $490 \mathrm{Ma}$ and $340 \mathrm{Ma}$.

$\mathrm{CLO}=$ Central Lachlan Orogen; ELO = East Lachlan Orogen; NEO = New England Orogen; WLO = West Lachlan Orogen; WOMB $=$ Wagga-Omeo Metamorphic Belt
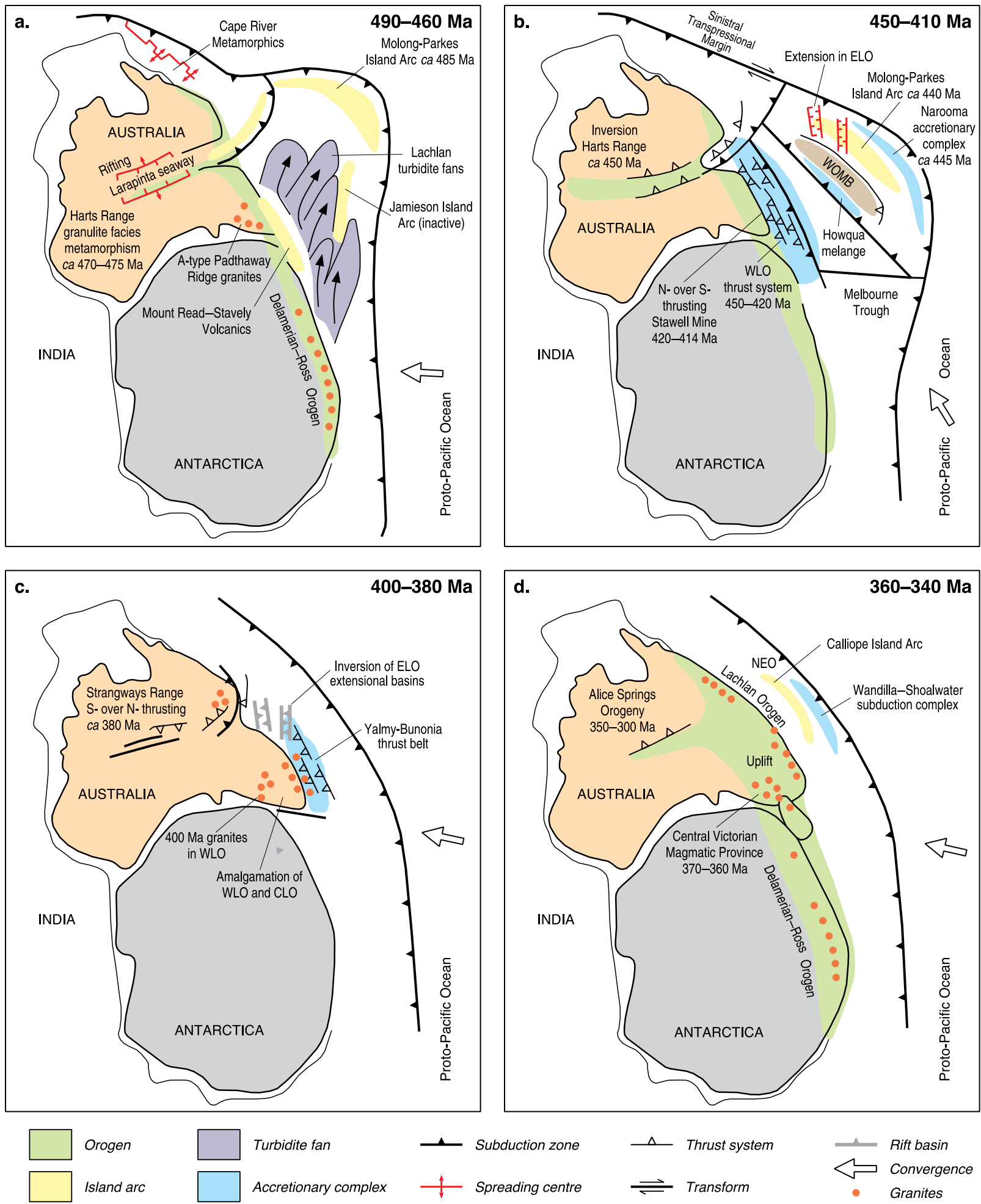


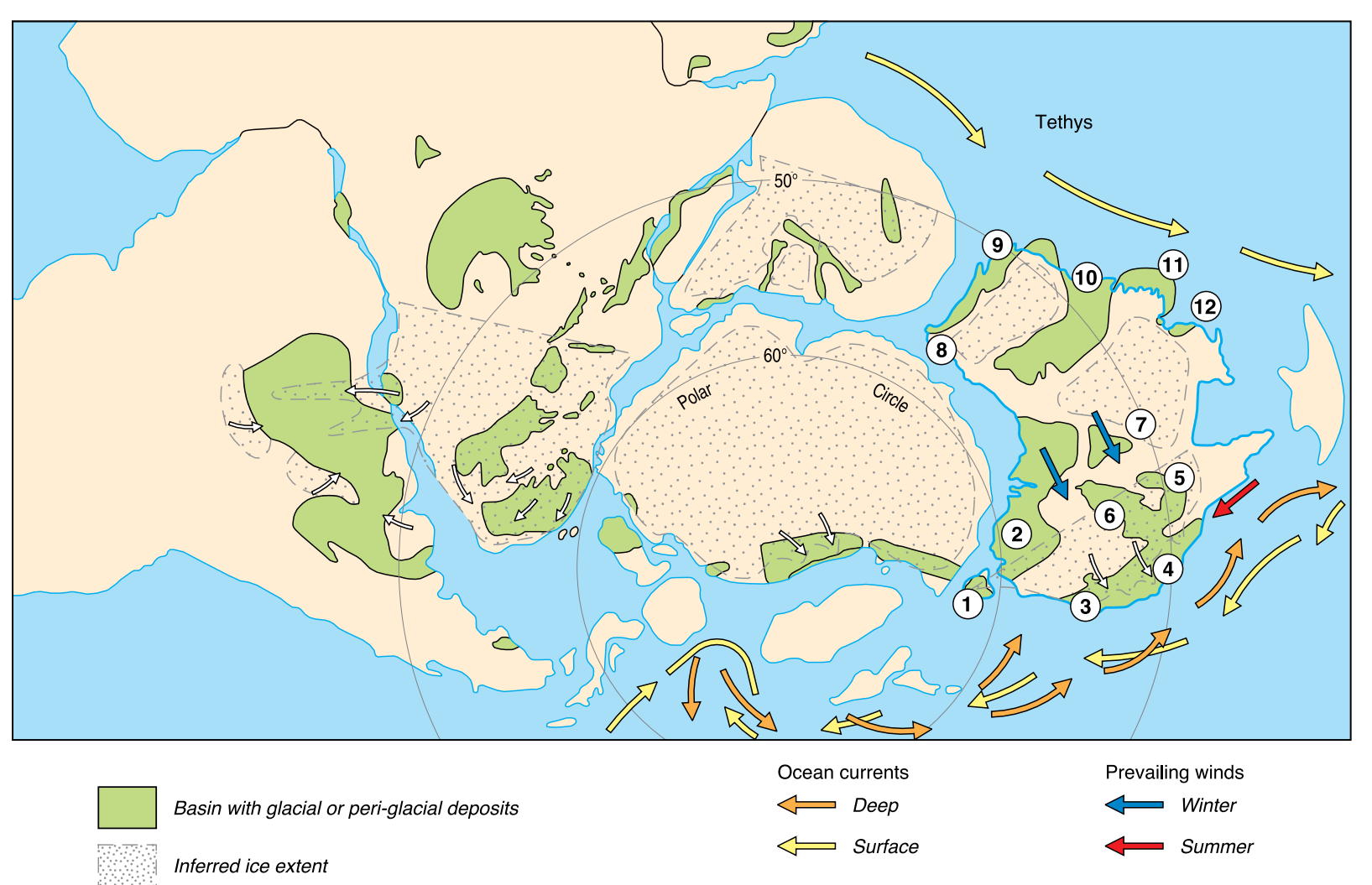

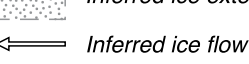

(1) Tasmania

(7) Pedirka-Arckaringa

(2) Murray

(8) Perth

(3) Sydney

(9) Carnarvon

(4) Bowen

(10) Canning

(5) Galilee

(11) Browse

(6) Cooper

(12) Bonaparte

Figure 2.35: Gondwana reconstruction from the late Carboniferous to early Permian. Sedimentary basins formed across much of Australia at this time, some being the sites of major coal and coal-seam gas resources (Chapter 9). Australia and Antarctica were tightly coupled in East Gondwana. Australia was completely separated from the Antarctic vestige of Gondwana at $34 \mathrm{Ma}$, becoming an island continent in the geologically recent past (Figure 2.20). (Source: after López-Gamundí, 2010)
Larapintine has also been used to describe the particular petroleum systems related to oil source rocks deposited in warm, shallow seas during the early Paleozoic in onshore Australia (Chapter 4). The largest commercial Larapintine petroleum accumulations are the Palm Valley gas field and Mereenie oil field in the Amadeus Basin in central Australia (Figure 2.21b). Ordovician organic-rich marine sediments provide the source rock and seal for the gas and oil in underlying sandstone reservoirs. Giant anticlines, formed during the Alice Springs Orogeny, provide the structural architecture for the hydrocarbon traps. However, in comparison with younger systems (see below and Chapter 4), the Larapintine system was very minor $(<10 \%$ of Australia's total hydrocarbon resources).

In central Australia, the intraplate Alice Springs Orogeny was a succession of contractional events that inverted large parts of the Larapintine Seaway. Prior to this, the basins of the Centralian Superbasin (Amadeus, Georgina, Wiso and Ngalia) were contiguous. The orogeny was intense: deep crustal rocks were exhumed some $30 \mathrm{~km}$ and juxtaposed with undeformed rocks of similar age. As part of this orogeny, the south-directed Redbank Shear Zone offset the Moho, creating one of the largest gravity gradients on Earth (Figure 2.12). The spectacular MacDonnell Ranges at, and near, Alice Springs comprise Amadeus Basin sediments tilted as a consequence of exhumation associated with the Redbank Shear Zone (Figure 2.31). The Alice Springs Orogeny also produced topographic relief. This topography resulted in the development of foreland basins and possibly the topographic 
head that drove hydrothermal fluid flow in the Mississippi Valley-type $\mathrm{Pb}-\mathrm{Zn}$ deposits of the Canning Basin (Figure 2.33).

The assembly of the continents into Pangaea led to extensive glaciations in the late Carboniferous and Permian (Figure 2.35). Streams of ice entered Australia from the uplands of Antarctica to the south, bringing glacial debris into the sedimentary record, with extensive deposition in central Australia and in the rift sequences along the western margin, in the Perth, Carnarvon and Bonaparte basins. The Permian glaciation also removed or modified much of the arid zone's pre-existing landscape, although large tracts were ice free. An example is the deep oxidation, visible to more than $60 \mathrm{~m}$ depth, in the Au deposits of the Tanami Desert region in the Northern Territory (Figure 5.3b). Deep Permian-aged oxidation was likely enhanced by the fact that the atmosphere may have contained $50 \%$ more oxygen than today. A further example of Permian weathering is the karst system developed at $345 \mathrm{Ma}$ in the Jenolan Caves to the west of Sydney, making these the oldest currently open cave system in the world. It is possible that some of these old landscapes have been formed, buried and more recently exhumed, rather than being continuously exposed for hundreds of millions of years (Chapter 5).

\section{0}

Gondwana breakup seen by Jurassic (ca $175 \mathrm{Ma}$ ) dolerite tors on Mt Wellington, Tasmania. o Getty Images [G Dixon]

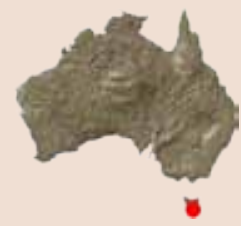

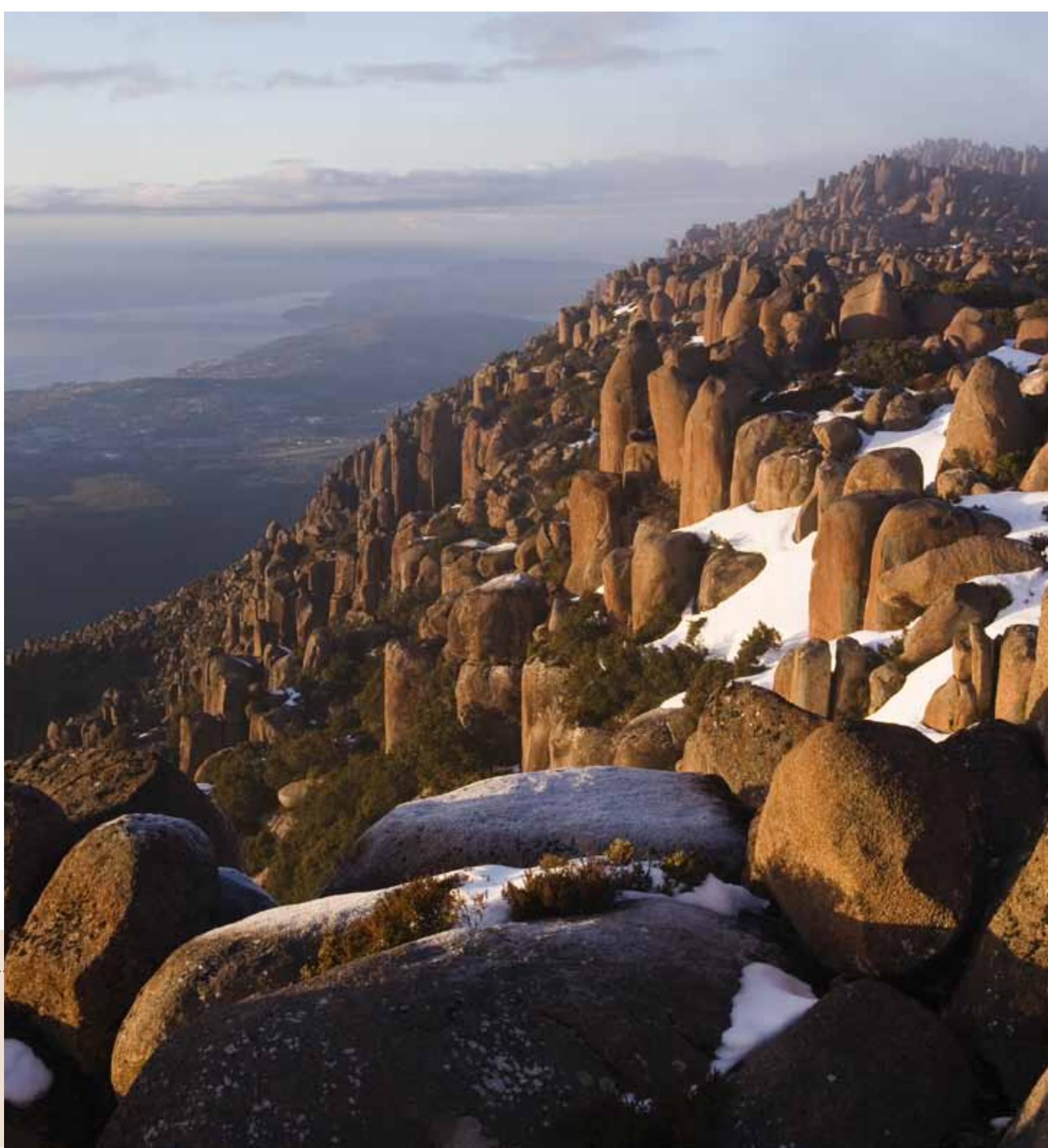


The vast Permian coal deposits of the SydneyBowen-Gunnedah basin system in eastern Australia formed in a foreland basin behind the continental volcanic arc system of the New England Orogen. Counter-flow in the mantle wedge above the subduction zone is thought to have created the slowly subsiding accommodation space for the thick accumulation of the coal measures. The cool high-latitude plate position of Australia at this time, an environment similar to the modern Russian taiga, permitted the accumulation of vast amounts of peat from Glossopteris and other species. These peat seams, accumulated over hundreds of thousands of years, were compacted into black coal, with the largest seam at Blair Athol being $31 \mathrm{~m}$ thick (Chapter 9).

\section{0-160 Ma-breakup of Pangaea}

After final amalgamation around $250 \mathrm{Ma}$, Pangaea lasted less than 100 Myr before it started to break apart. This breakup initiated at around $180 \mathrm{Ma}$ as the Atlantic Ocean and Tethys Sea began to form, separating Gondwana (which included Australia, Antarctica, South America, Africa and India) from Laurasia (which included North America and Eurasia). During the Triassic, the western margin underwent a series of transpressional events, known collectively as the Fitzroy Movement. Ongoing subduction occurred along the eastern margin of the continent, with widespread volcanoclastic detritus being deposited in the Eromanga and Surat basins. The emplacement of voluminous ca 175 Ma tholeiitic dolerite sills, which form part of the Karoo-Ferrar Large Igneous Province in Tasmania, presaged the breakup.
One of Australia's iconic rocks, the Hawkesbury Sandstone of the Sydney Basin, was deposited as Pangaea broke up. This quartz-rich sandstone was both a boon and a drawback to the growing colony of New South Wales. Ideally suited for building because it is both durable and easily worked, it was used to construct many public buildings in Sydney, including Government House and the older buildings at the University of Sydney. However, soil that developed on the Hawkesbury Sandstone was poor, and escarpments formed from it were a major impediment to exploration and settlement across the Blue Mountains west of Sydney. On the western margin of the continent, vast delta systems poured sediment onto the North West Shelf, creating the Triassic-aged reservoir rocks for Australia's vast hydrocarbon resources (Chapter 4).

\section{0-65 Ma-breakup of Gondwana and creation of Australia}

Gondwana began to fragment in the Jurassic, as East and West Gondwana separated with seafloor spreading between Africa and Madagascar, and the Atlantic Ocean started to open between Africa and South America. A triple point of extension, centred just southwest of Perth (WA), cut the jigsaw between India, Antarctica and Australia. The northwest margin of Australia had formed by $154 \mathrm{Ma}$, as the last of a series of continental slivers, Argo Land in Burma, rifted away. By $120 \mathrm{Ma}$, the breakup had extended far into Gondwana, separating Australia from Greater India, and the entire west coast of Australia faced the Indian Ocean. A series of panels illustrating the breakup is given in Chapter 4 .
Australia unzipped from Antarctica via an easterly-propagating rift system. Rift basins had begun to form as far east as the Polda Basin in South Australia at $155 \mathrm{Ma}$. By $145 \mathrm{Ma}$, rifting in the Gippsland Basin, Victoria, had occurred. By $120 \mathrm{Ma}$, volcanic detritus was flooding into eastern Australia (Eromanga Basin), and rifting stopped in the Bass Basin. The Large Igneous Province of Kerguelen started to form around 118-110 Ma and the Broken Ridge around $95 \mathrm{Ma}$ (Figure 2.1), while volcanism continued on the Lord Howe Rise (now submerged off eastern Australia).

During the Cretaceous, a large inland sea formed across much of eastern Australia (Box 4.3). This Eromanga Basin is up to $1200 \mathrm{~m}$ thick and covers several older basins. Some workers have suggested that remnants of the west-directed subduction zone slab, which dominated the tectonics of eastern Australia, continued to exert an influence by descending in the mantle and drawing down the lithosphere, creating the accommodation space for the Eromanga Basin sediments. This concept helps explain why much of eastern Australia was inundated by sea in the Early Cretaceous but largely high and dry in the Late Cretaceous when global sea-levels were at their highest (Chapter 4). Along the southern margin, the giant Ceduna delta partly filled the seaway between Antarctica and Australia with continental detritus.

By $95 \mathrm{Ma}$, the longstanding west-directed Palaeopacific Ocean subduction zone beneath eastern Australia retreated to the east. This event coincided with uplift and formation of the eastern highlands of Australia (95-85 Ma), including 
uplift and erosion of the Eromanga Basin. By this time, a significant seaway had developed between Australia and Antarctica, though there was still connection through Tasmania. Breakup could have occurred to the north of Tasmania through the Bass Strait region where the rift basins of the Otway, Bass and Gippsland lie. The dolerite massif of Mt Wellington, which stands above present-day Hobart, is a legacy of earlier attempts at rifting. The thinning of the crust was accommodated by basin formation in the Gippsland and Bass Strait areas, creating one of Australia's main hydrocarbon provinces (Chapter 4).

Rifting along the east coast began before $c a 85 \mathrm{Ma}$ in the south, and propagated northwards, resulting in the opening of the Tasman Sea, taking the Lord Howe Rise and New Zealand to the east. The former links to the other parts of Gondwana remain evident through associations of flora and fauna (Chapter 3). The Southern beech, Nothofagus, is today found in Tasmania, New Zealand and southernmost South America. Australia even has a native rhododendron whose nearest relatives are in the Himalaya. The distinctive marsupial populations of Australia are a thriving remnant of a distribution that once spread across the southern continents (Chapter 3).

Figure 2.36: Summary of the climate of Cenozoic Australia inferred from sedimentological and palaeontological evidence in inland and southern marginal basins and from weathering regimes. Oxygen isotopes are proxies for ocean temperature, data sourced from deep-sea drilling cores. The low $\delta^{18} \mathrm{O}$ values correspond to warmer periods, and the onset of cooling and glaciation is marked by a sharp rise in the $\delta^{18} \mathrm{O}$ values.

(Sources: after Fujioka \& Chappell, 2010, and references therein)

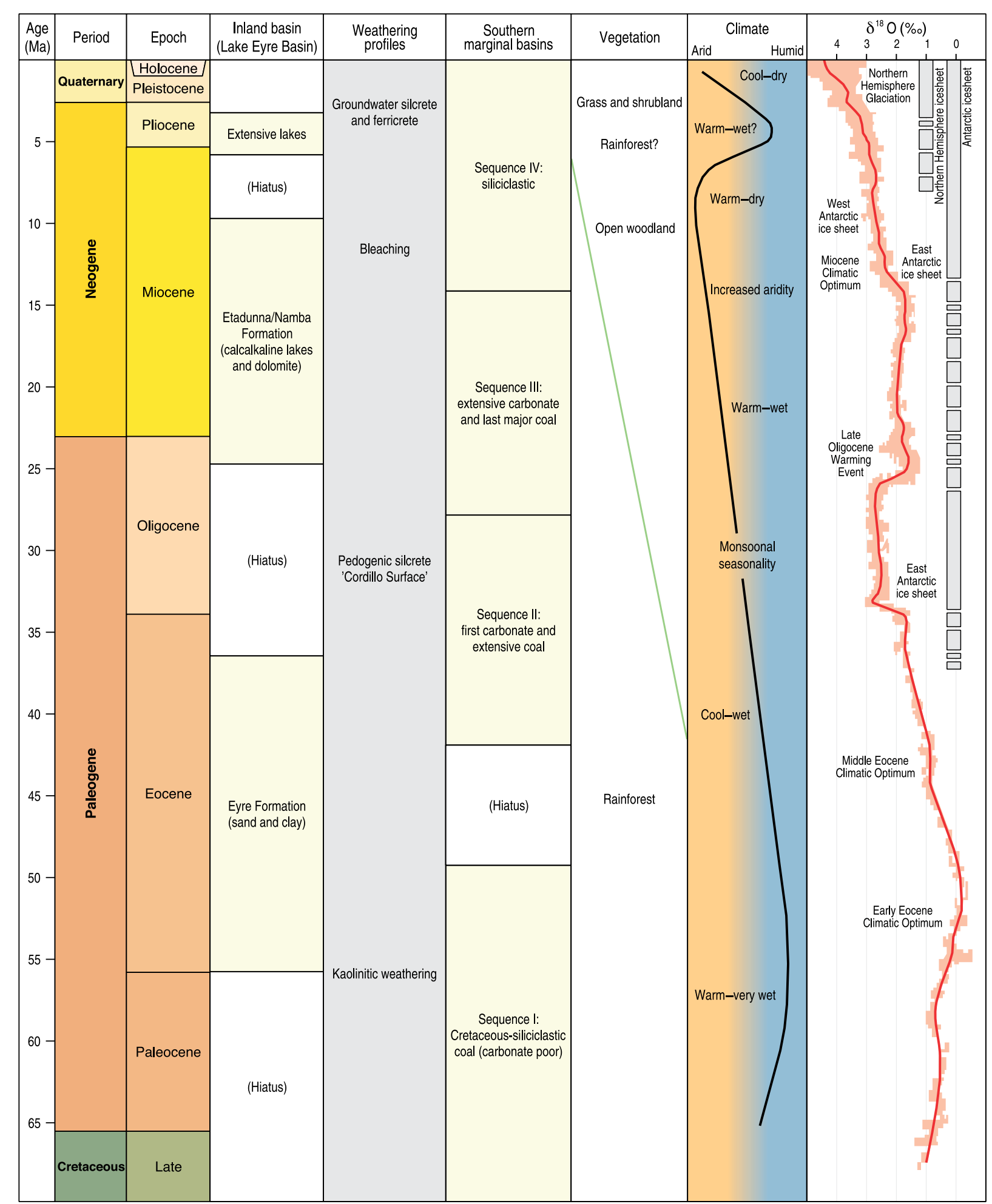




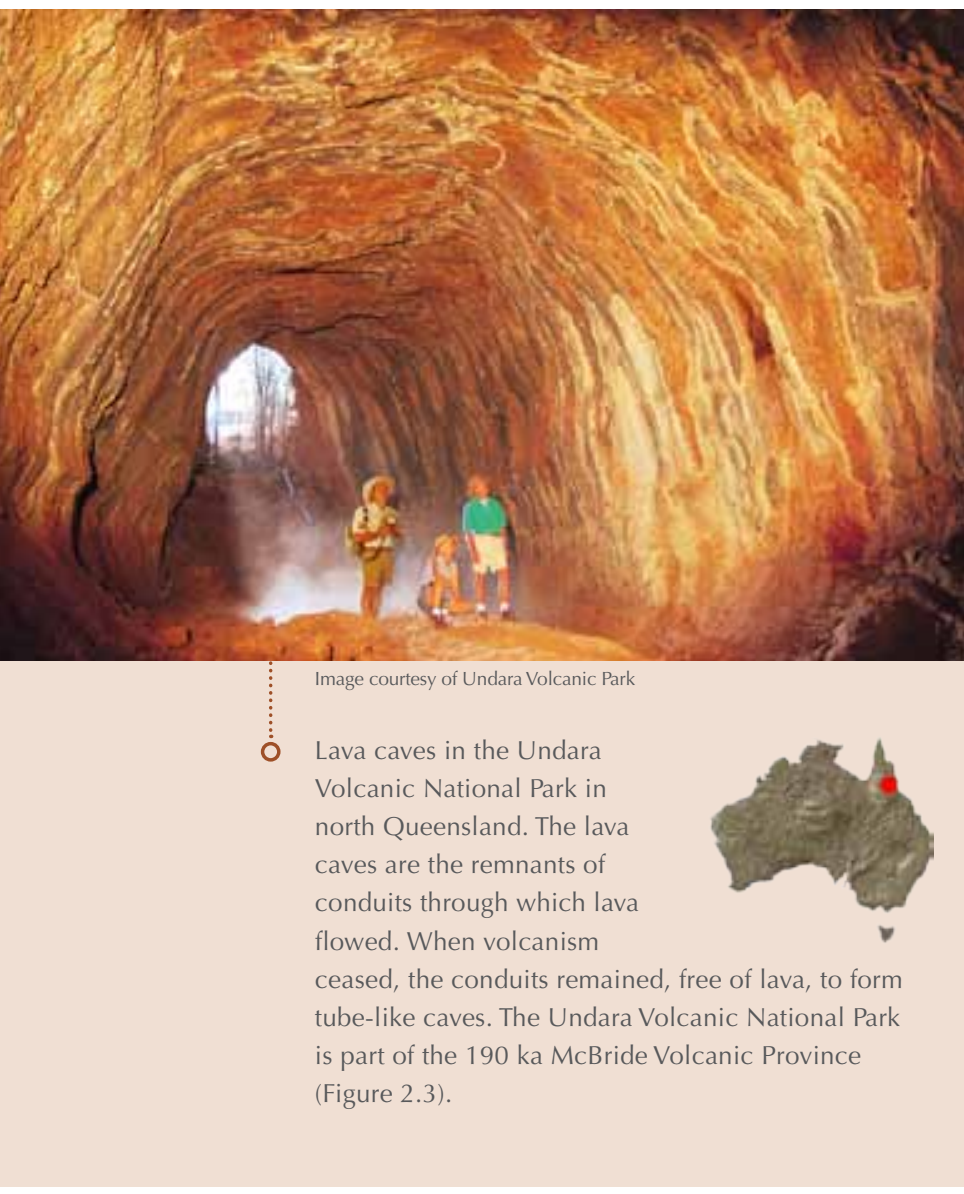

Mesozoic weathering and landscapes continued to develop, especially on granitic rocks in eastern Australia. By the end of the Cretaceous, the fundamental physiography and the palaeovalley architecture of today's arid Australia was established. These palaeovalley systems formed as a network of wide and shallow valleys in the landscape, but without sediment infill. Many of these palaeovalleys are important groundwater aquifers (Chapter 7). Some of these landscapes are as old as the Cambrian, but they are unlikely to have remained continuously exposed at the surface for this duration. Fission-track dating suggests that these very ancient landscapes were exposed, then buried and finally more recently exhumed (Chapter 5).

\section{5-2.6 Ma-Australia girt by sea}

The past 65 Ma have left an extensive imprint on the Australian continent, with around $80 \%$ of the surface geology of Australia comprising Cenozoic rocks of some kind (Figure 2.7). Most of this cover consists of thin aeolian sand, lakes and fluvial deposits. Locally, discrete basin entities developed, such as the Eucla Basin in Western Australia, the Murray Basin in southeastern Australia and the Karumba Basin in northern Australia, as well as their offshore extensions (Figure 2.9). Knowledge of Cenozoic Australia comes from the combined study of landscape, stratigraphy, palaeontology, isotope geochemistry and geochronology (Figure 2.36).

By $65 \mathrm{Ma}$, oceanic crust floored the Southern Ocean as far east as western Victoria. Further to the east and the south, the crust was very thin at this time, but a connection with Antarctica remained as sediments sourced from the south were deposited in the sag phase of the Sorell Basin off the west coast of Tasmania. The Ceduna delta system was abandoned at this time. Seafloor spreading started with the opening of the Coral Sea and the Queensland Plateau at around $60 \mathrm{Ma}$. Following breakup, Australia's initial drift was to the northwest. But a ridge subduction in the northwest Pacific at around $52 \mathrm{Ma}$ resulted in termination of Tasman Sea spreading and a change in the Australian Plate vector to its present-day northerly direction. Seafloor spreading in the Southern Ocean accelerated at around $45 \mathrm{Ma}$, and it was not until $34 \mathrm{Ma}$ that full separation of Australia and Antarctica occurred. Australia, as a separate continent, was released from the remnants of Gondwana and commenced the northward march to meet Asia.

The formation of the passive margins not only created most of Australia's hydrocarbon plays, but also preserved the huge energy reserves in coal and coal-seam gas along the eastern margin. If the Pacific-Australian Plate subduction margin, now in New Zealand and Fiji, had remained just offshore of New South Wales and Queensland, then these easily won energy resources may have been destroyed or rendered uneconomic (Chapter 9). Had this rollback of the subduction zone not occurred, maybe the mountains, and thus ski fields, of southeast Australia might have been world class.

From about $45 \mathrm{Ma}$ to $10 \mathrm{Ma}$, Cenozoic sediments were deposited in the Lake Eyre $(360 \mathrm{~m})$, Eucla (750 m onshore, to $6 \mathrm{~km}$ offshore), Karumba (up to $1700 \mathrm{~m}$ offshore) and Murray $(600 \mathrm{~m})$ basins. The climate was warmer and wetter than today, 
and rainforests were extensive (Figure 2.36). During this time, the sea made several incursions onto the land. The Eocene (42.5-34 Ma) and MiocenePliocene (15-2.6 Ma) shorelines preserved along the Eucla Basin margin are good examples of these repeated incursions. These marine incursions have left a legacy of salt, which today is being mobilised into the present-day rivers and groundwater. These incursions have also deposited sulfur in some coal and lignite deposits, rendering them less suitable to use. Most of the salt burden contained in Australian soils is, however, a function of aeolian salt carried directly from the sea or as dissolved salt carried in rainwater. Salt remains in the Australian landscape because the continent's river systems either do not drain into the sea or, if they do, are sluggish and have low discharge rates (Chapter 5).

Major palaeovalley systems provided detritus to the Cenozoic basins and their offshore extents (Figure 2.37). Some palaeovalleys were shaped by older landscape features. The general pattern of these palaeovalleys across Australia is an early Cenozoic fluvial succession of sand, overlain by a mid-Cenozoic succession of fine-grained lacustrine sediments. These palaeovalleys are known for a variety of resources, including iron ore, $\mathrm{U}$ and groundwater (Chapter 7). For example, a significant proportion of the Hamersley iron ore production in the Pilbara (WA) comes from pisolitic iron that formed in the Robe and Yandi palaeochannels, which were active at around $30 \mathrm{Ma}$ (Figure 2.33). In this region, late-stage goethite mineralisation has been dated at $18 \mathrm{Ma}$ near the surface, and $5 \mathrm{Ma}$ at depth, reflecting the progressive lowering of the water-table as northern Australia became more arid (Chapter 5).

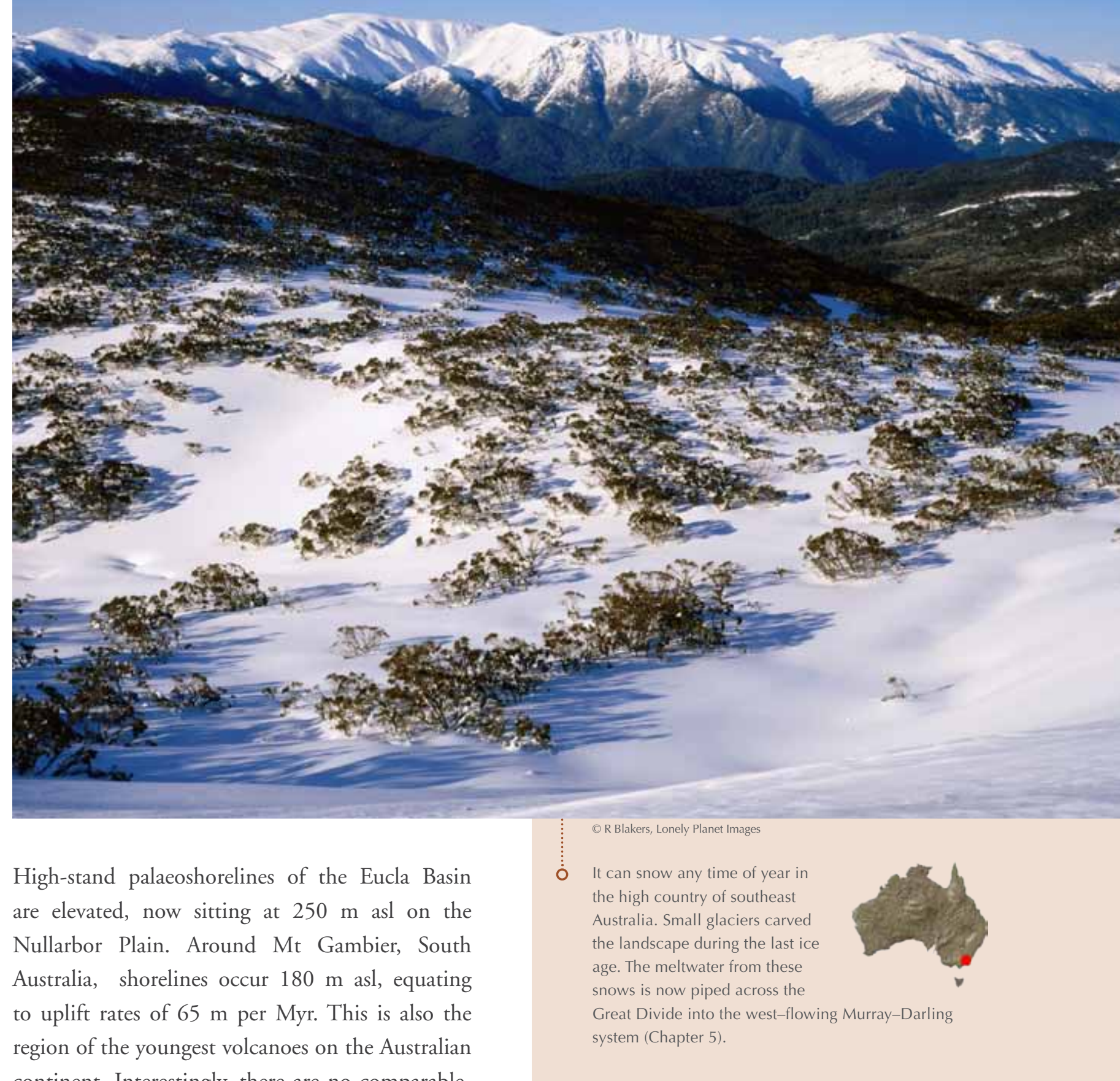

continent. Interestingly, there are no comparableaged marine shorelines exposed on the north coast. Possibly, there was a northward tilting of the plate, caused by the subduction pull of the northern margin (Chapter 6). Some of these Cenozoic palaeoshorelines contain economic concentrations of rutile, zircon, ilmenite, and minor leucoxene and monazite (Figures 2.33 and 2.37). 


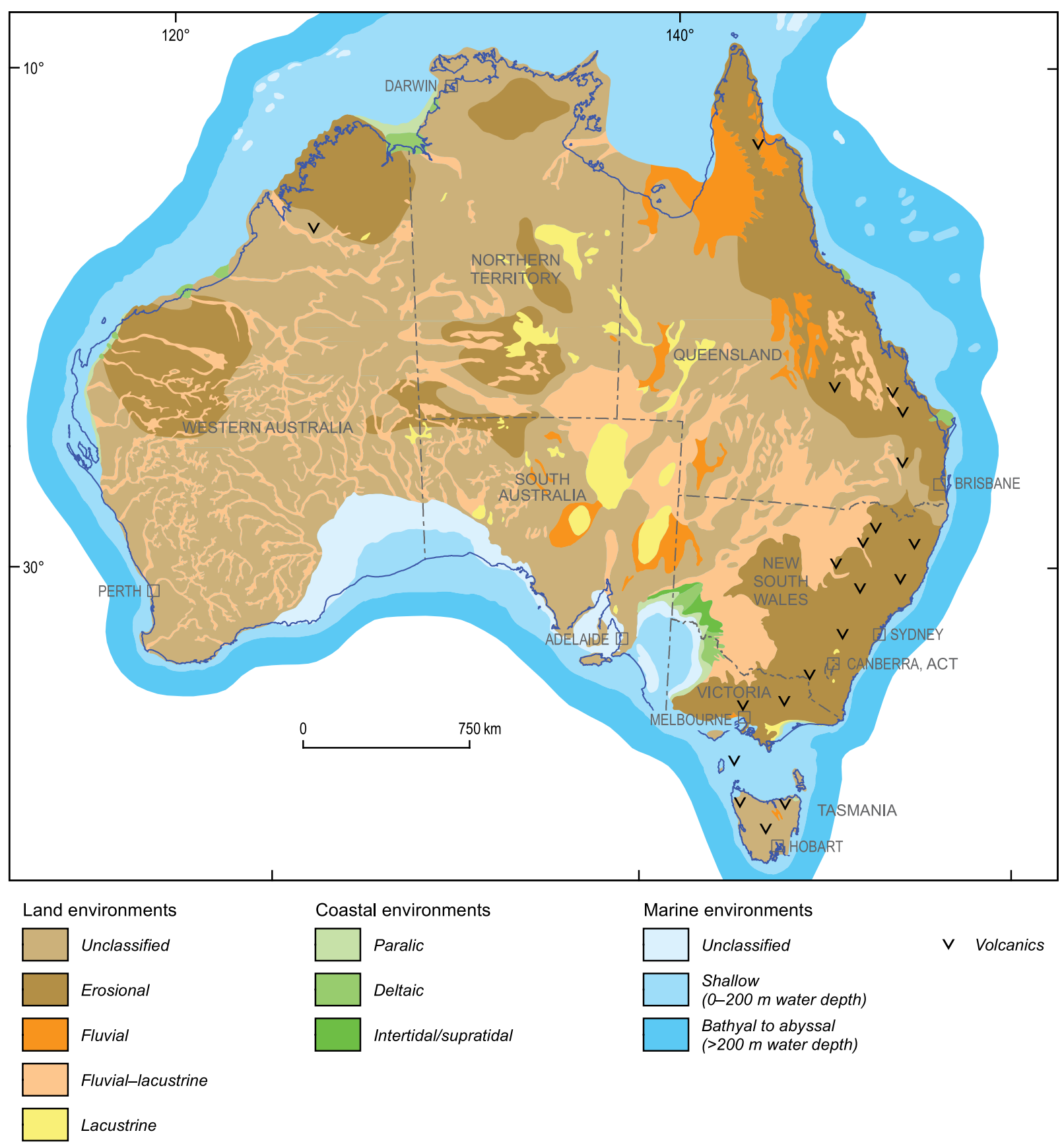

Figure 2.37: Map of the environments during Cenozoic Australia, between $30 \mathrm{Ma}$ and $10 \mathrm{Ma}$.
The brown coals of the La Trobe Valley in southeast Victoria, which are burnt in power stations today, are up to $130 \mathrm{~m}$ thick. They were formed between $30 \mathrm{Ma}$ and $20 \mathrm{Ma}$, when the climate was humid. Similarly, the oil-shale resources near Gladstone in Queensland (Figure 2.21b) and diatomite deposits from the Warrumbungles (NSW) into southeast Queensland were also formed in lacustrine basins at this time.

The Ellendale lamproite field (WA) was emplaced around $25 \mathrm{Ma}$, probably as a result of a short-lived mantle hotspot. More than 80 separate pipes cross the northern margin of the Canning Basin, which marks a persistent zone of continental weakness adjacent to the very resistant margin of the Kimberley Craton. Along the eastern margin of the continent, gemstones were carried in eruptions associated with the Newer Volcanic Group as the Australian Plate moved northwards over mantle hotspots. At $32 \mathrm{Ma}$, the Mount Dukes Intrusive Complex in tropical northeast Queensland contains the youngest granite known on the Australian mainland (Figure 2.3). This granite was comagmatic with the shield volcanoes common to the east coast.

Australia and Antarctica-and South America and Antarctica-had separated sufficiently at around $25 \mathrm{Ma}$ for full circulation between the Southern and Pacific oceans to occur. Although polar glaciation had started in West Antarctica around $34 \mathrm{Ma}$, the great ice sheet on Antarctica began to develop around 15-10 Ma in the east and 10-6 Ma in the west. The formation of the Antarctic ice sheet fundamentally altered Earth's marine and 
terrestrial climate and sea-levels. The impacts on Australia were large, as the meridional temperature gradients steepened and the subtropical monsoon contracted northwards, which placed much of the continent in the drier mid-latitudes (Figure 2.36).

The late early Miocene ( $c a 16 \mathrm{Ma}$ ) was the climax of a Neogene warm period, followed by cooling and increasing aridity. Opal began to be deposited, such as in Coober Pedy (SA), at this time and during punctuated intervals thereafter. Deep oxidation and weathering occurred in southeast Australia in the Miocene. Between $16 \mathrm{Ma}$ and $12.9 \mathrm{Ma}$, there were major short-term climate fluctuations. This was the period of the stabilisation of the East Antarctic ice sheet. The boundaries between climatic zones strengthened, which led to the increased aridification of mid-latitude continental regions in Australia, Africa, and North and South America. Grasslands developed, stimulating the evolution of grazing mammals (Chapter 3), and in Australia the rainforests retreated (Figure 2.36).

By $10 \mathrm{Ma}$ (Late Miocene), Australia had moved northwards into a latitudinal position similar to that of today. Sea-levels were lower, so that much of the continent was exposed to weathering and erosion (Chapter 5). Pollen evidence shows that the period between ca $5 \mathrm{Ma}$ and $c a 2 \mathrm{Ma}$ was wet in Australia, with rainforests again supported (Figure 2.36). The extensive cave systems of the Nullarbor Plain formed in the uplifted marine sediments of the Eucla Basin. Recent dating has shown a range in ages of these speleothems, from 7.5 Ma to $c a 1 \mathrm{Ma}$, with a distinct peak in cave formation between 4.1 Ma and 3.5 Ma.
The Cenozoic tectonic history of Australia was not entirely associated with breakup. The active convergence that is still occurring today along Australia's north commenced at about $40 \mathrm{Ma}$. Timor is now accreted onto the Australian Plate and is moving together with Australia. Collision with proto-Indonesia and related fragments caused the cessation of carbonate shelf deposition and initiation of widespread siliciclastic sedimentation on top of the Australian continental basement at about 12 Ma. The collision emplaced the Irian (West Papua) ophiolite and created the present mountainous topography that forms the spine of the island of New Guinea. A well-developed fold-thrust belt has grown over the Australian Plate margin in the southern part of New Guinea; this active seismic region has folds developing today. The foreland basins created by Australia's collision also host the giant accumulations of hydrocarbons (such as the Tangguh and Hides gas fields). The collision and underlying structure of the Australian Plate also control the location of the region's giant $\mathrm{Cu}-\mathrm{Au}$ deposits (such as Grasberg and Ok Tedi).

Convergence and major dextral strike-slip faulting commenced around $5 \mathrm{Ma}$ across the Australian Plate boundary in New Zealand. This resulted in far-field shortening across Australia, and renewed uplift along the eastern highlands and the Flinders Ranges (SA). Present-day convergence along the eastern plate margin contributes to the continent's stress regime and earthquake hazard (Figure 2.2).

Towards the end of the Pliocene, the climatic zones now governing Australia had become established, although the climate was often wetter than today.
The pace of climate change increased, as the Quaternary glacial cycles commenced, including the expansion of ice caps in the Northern Hemisphere around $3 \mathrm{Ma}$. In the African savanna, along the widening eastern rift valleys, early hominins were evolving.

\section{6-0 Ma-evolution of modern Australia}

One of the difficulties in understanding the Australian landscape is that it is a complex mosaic of many superimposed landscapes that developed during vastly differing climatic conditions. For example, many of the features of Quaternary Australia were inherited from landscapes as old as the Cambrian (Chapter 5). The preservation of these ancient landscapes and its regolith is a function of the tectonic stability afforded by the old cratonic roots of the continent and the plate position during the Pleistocene to Holocene. Most of Australia avoided the physical rigours of the last ice ages, with glaciers limited to the southeastern highlands.

The Pleistocene and Holocene ice age impacts in Australia were driven by cycles of aridity, which were linked to the glacial-interglacial cycles. In Tasmania, the maximum ice extent occurred at $c a 1 \mathrm{Ma}$, with later advances in the past $100 \mathrm{kyr}$ being less extensive. During these glacial episodes, atmospheric circulation intensified, with a reduction in atmospheric moisture and an increase in 'continentality' because of lower sea-levels (Box 2.6). The net water budget reduced, due to decreased precipitation and increased wind-enhanced evaporation. Aeolian processes 


\section{OCEANS TO ICE-QUATERNARY CLIMATE AND SEA-LEVEL CYCLES (вох 2.6)}

Global changes in climate over several million years are recorded in oxygen $(\mathrm{O})$ isotopes preserved in the tests of fossil Foraminifera that have been buried in deep-sea sediments. Figure B2.6a shows a time series of these data for the last $4 \mathrm{Myr}$ derived from several sediment cores. The lower values in this graph reflect periods of warm global temperature when there was a greater relative abundance of the lighter $\mathrm{O}$ isotope, ${ }^{16} \mathrm{O}$, in seawater and the calcium carbonate $\left(\mathrm{CaCO}_{3}\right)$ tests of the foraminiferans.

Conversely, higher values reflect periods of cool global temperature, when more of this $\mathrm{O}$ isotope was locked up in ice caps. Likewise, sea-level was higher in the warm periods and lower in the cool periods. The trend line displays the decline in global temperatures and sea-level since the Late Miocene and the onset of lower, more variable global temperature and sea-level in the Quaternary (last ca 2.6 Myr), especially during the last $800 \mathrm{kyr}$

Large, regular fluctuations in sea-level have occurred over the Quaternary as the ice sheets grew and then melted, approximately every $100 \mathrm{kyr}$ (Figure B2.6b). The record of sea-level change for the last glacial cycle (130 ka to present, Figure B2.6c) reveals well the second-order fluctuations in sea-level that occur within a glacial cycle. These data show that sea-level is rarely stable over geological time-scales and has seldom sat at its present high position. Note that the arrival of humans between $55 \mathrm{ka}$ and $21 \mathrm{ka}$ occurred when sea-level was $60 \mathrm{~m}$ to $125 \mathrm{~m}$ lower than today.
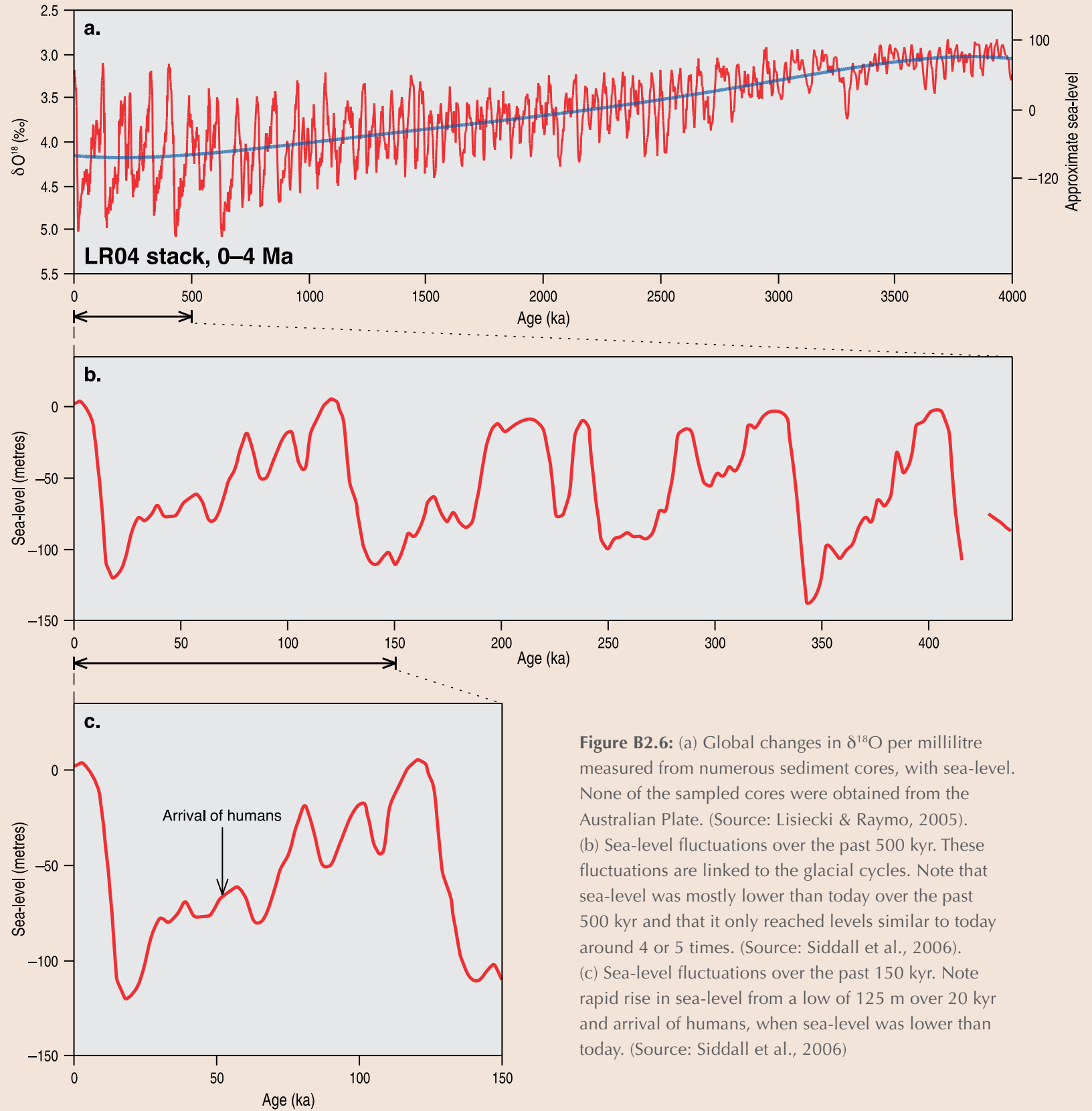

Figure B2.6: (a) Global changes in $\delta^{18} \mathrm{O}$ per millilitre measured from numerous sediment cores, with sea-level. None of the sampled cores were obtained from the Australian Plate. (Source: Lisiecki \& Raymo, 2005). (b) Sea-level fluctuations over the past 500 kyr. These fluctuations are linked to the glacial cycles. Note that sea-level was mostly lower than today over the past $500 \mathrm{kyr}$ and that it only reached levels similar to today around 4 or 5 times. (Source: Siddall et al., 2006). (c) Sea-level fluctuations over the past $150 \mathrm{kyr}$. Note rapid rise in sea-level from a low of $125 \mathrm{~m}$ over $20 \mathrm{ky}$ and arrival of humans, when sea-level was lower than today. (Source: Siddall et al., 2006) 
forests. This was the continent that the first Australians settled. The forests declined rapidly from about 45-42 ka, accompanied by an increase in native grasses (Poaceae) and biomass burning, all of which may be linked to human arrival and disturbance (Chapter 3).

The last glacial maximum saw Lake Eyre completely dry and exposed to the wind, which scoured its base and deepened the lake floor. Transport of dust was particularly active at $22 \mathrm{ka}$ and was likely active for a few thousand years before and after this event. Aeolian dust also mantled many of the hills and slopes of arid Australia, covering bare rocks and slopes and changing surface-water runoff. Towards $22 \mathrm{ka}$, continental Australia was $10^{\circ} \mathrm{C}$ cooler than today. It was also much drier and windier, and sea-level was around $125 \mathrm{~m}$ lower (Box 2.6).

The Sahul and Bass Strait land bridges connected the mainland with New Guinea and Tasmania. Perennial lakes existed in the Gulf of Carpentaria and Bass Strait. The river mouths were located at the edge of the continental shelf, which meant that the rivers were longer than today. Many of the rivers carved deep canyons into the outer continental slope, such as the Murray River (SA) and Perth (WA) (Chapter 6). The Murray Canyons are still active conduits for shelf-derived sediment transport to the abyssal plains, and the Perth Canyon is an important breeding ground for the endangered blue whale.

A spectacular $90 \mathrm{~m}$ high waterfall on the Yarra River crowned the entrance to what is now Port Phillip Bay near Melbourne. Aboriginal stories say it showered Point Nepean in a permanent mist. The local Boonwurrung Aboriginal people were known as the 'people-of-the-mist', and the traditional name for the Yarra was Birrarung, meaning 'river of mists'.

The climate warmed, sea-levels rose, and the land bridges were swamped around $6 \mathrm{ka}$. Palynology records the return of warmer and wetter climatic conditions, which saw the tropical rainforests expand between 8-6 ka and again at 3 ka (Chapter 3). Lake levels in western Victoria reached a maximum at $7.2 \mathrm{ka}$. After $5.5 \mathrm{ka}$, these lakes started to become more saline. Continental Australia still had volcanoes, the last being active around $4.6 \mathrm{ka}$ in Mt Gambier.

During the glacial maximum, drought and cold, together with the lower $\mathrm{CO}_{2}$ levels, would have had a negative impact on Australian trees and forests (Chapter 3). Grasslands and savanna became more dominant at this time. The widespread loss of trees and their associated deep roots led to rising groundwater tables, which brought salt closer to the land surface (Chapter 7).

Aboriginal and Torres Strait Islander people have occupied Australia at least since 55-45 ka. They have survived the many major climatic upheavals that have beset the country over these millennia. There are many examples of episodic occupation by Aboriginal people at specific sites. These patterns were driven by availability of water and food and sea-level. For example, at sites around Shark Bay on the mid-western Australian coast, there are records of two periods of occupation: firstly, during the late Pleistocene between $30 \mathrm{ka}$ and $18 \mathrm{ka}$, and secondly, during the Holocene between about $7 \mathrm{ka}$ and $6 \mathrm{ka}$. Rock shelters at the nearby Eagle Bluff and the Zuytdorp Cliffs were occupied around $4.6 \mathrm{ka}$. Other sites at Monkey Mia and Useless Loop show that the current period of occupation began about $2.3 \mathrm{ka}$. When people returned to Shark Bay in more recent times, they came primarily to hunt turtles, dugongs and land mammals.

\section{To sum up}

The geological evolution of Australia is a fascinating microcosm of the evolution of planet Earth. The fundamental features of Australia's geology, including the climate, environment, wealth and landscape, have shaped the Australian people in many ways. The first Australians-the Aboriginal and Torres Strait Islander peoplewhose beliefs, customs and extraordinary culture extend back millennia, have also been shaped by Australia's remarkable geology. In turn, they shaped the landscape to their needs and adapted to the remarkable changes in climate over the past 60-50 kyr. The Anthropocene is an epoch of dramatic change. How Australians living today will deal with change will, in many ways, be shaped by the geological heritage of this continent (Chapter 11).

In the next chapter, we go back to the beginning and look further at the astonishing changes in the life forms in Australia through geological time. 


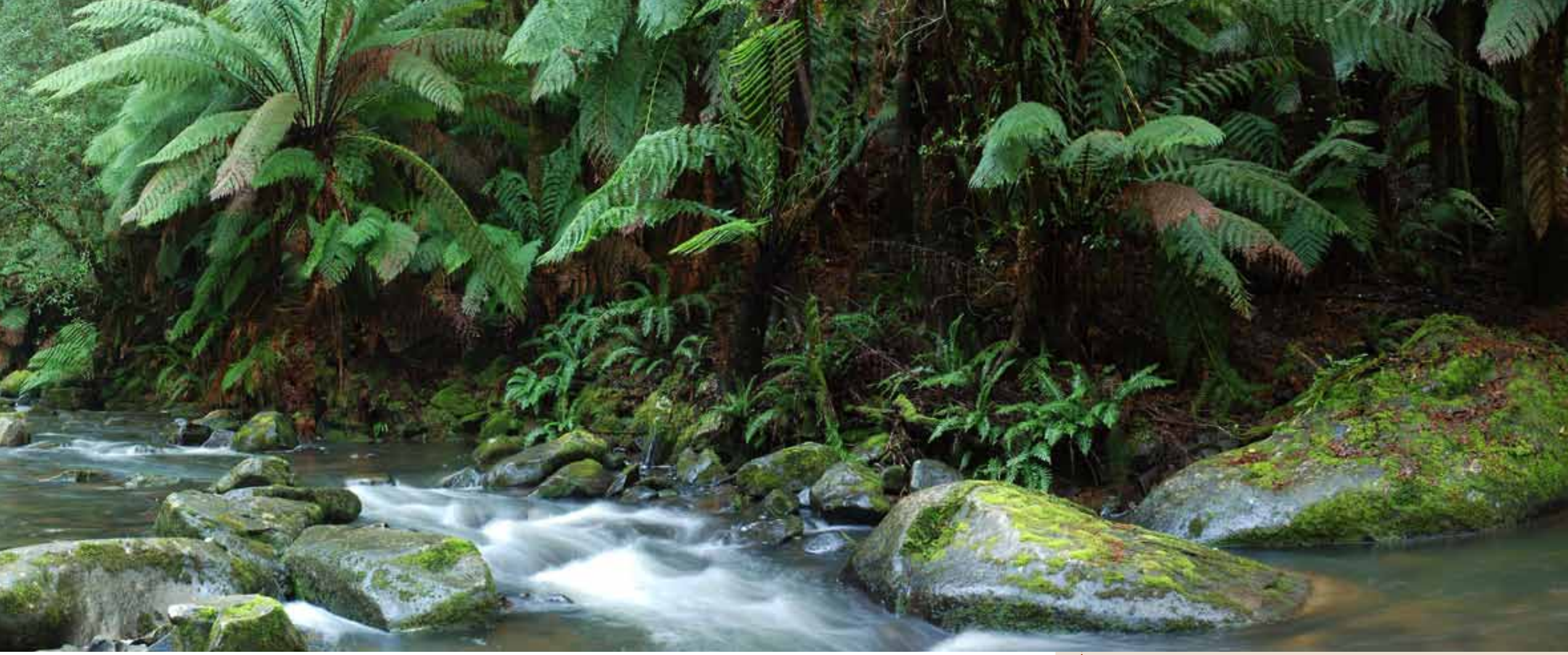

\section{Bibliography and further reading}

\section{Australia's current tectonic setting}

Braun J, Dooley J, Goleby B, van der Hilst R \& Klootwijk C (eds) 1998. Structure and evolution of the Australian continent, Geodynamics Series 26, American Geophysical Union, Washington.

DeMets C, Gordon RG \& Argus DF 2010. Geologically current plate motions. Geophysical Journal International 181

Ferrett R 2005. Australia's volcanoes, Reed New Holland, Chatswood.

Graham I (ed) 2008. A continent on the move: New Zealand geoscience into the 21st century, Geological Society of New Zealand, Wellington.

Hillis RR \& Reynolds SD 2003. In situ stress field of Australia. In: Evolution and dynamics of the Australian Plate. Hillis RR \& Müller RD (eds), GSA Special Publication 22 and GSA Special paper 372, 49-60.
Quigley MC, Clark D \& Sandiford M 2010. Tectonic geomorphology of Australia. In: Australian landscapes, Bishop P \& Pillans B (eds), Geological Society, London, Special Publications 346, 243-265.

Royer J-Y \& Gordon RG 1997. The motion and boundary between the Capricorn and Australian Plates. Science 277 $1268-1274$

Tagliabue A, Bopp L, Dutay J-C, Bowie AR, Chever F, Jean-Baptiste P, Bucciarelli E, Lannuzel D, Remenyi T, Sarthou G, Aumont O, Gehlen M \& Jeandel C 2010.

Hydrothermal contribution to the oceanic dissolved iron inventory. Nature Geoscience 3, 252-256.

Thornton W 2007. Tnorala-baby falling. CAAMA Collection, Ronin Films, Canberra.

Tregoning P 2002. Plate kinematics in the western Pacific derived from geodetic observations. Journal of Geophysical Research 107, 1-8.

Tregoning P 2003. Is the Australian Plate deforming? A space geodetic perspective. In: Evolution and dynamics of the Australian Plate, Hillis RR \& Müller RD (eds), Geological Society of Australia Special Publication 22, 41-48.
The Otway Ranges, a fine example of Cool Temperate Rainforest in southwest Victoria. Over $80 \%$ of this bioregion still has a cover of native vegetation, and $22 \%$ is in formal reserves.

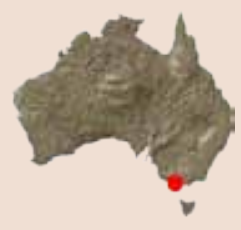




\section{Mapping Australia}

Aitken ARA 2010. Moho geometry gravity inversion experiment (MoGGIE): a refined model of the Australian Moho, and its tectonic and isostatic implications. Earth and Planetary Science Letters 297, 71-83.

Australian dictionary of biography, 2006-11, National Centre of Biography, Australian National University, Canberra. http://adb.anu.edu.au

Australian Greenhouse Office 2005. National Carbon Accounting System, Canberra. www.greenhouse.gov.au/ncas

Birch WD 2003. Geology of Victoria, Geological Society of Australia Special Publication 23

Branagan D 1986. Strzelecki's geological map of southeastern Australia; an eclectic synthesis. Historical Records of Australasian Science 64, 375-393.

Branagan D 2009. The Geological Society on the other side of the world. In: The making of the Geological Society of London, Lewis CLE \& Knell SJ (eds), Geological Society, London, Special Publication 317, 341-371.

Bureau of Mineral Resources, Geology and Geophysics 1979 Earth science atlas of Australia, Bureau of Mineral Resources, Geology and Geophysics, Canberra.

Burrett CF \& Martin EL 1989. Geology and mineral resources of Tasmania, Geological Society of Australia Special Publication 15.

Day RW, Whitaker WG, Murray CG, Wilson IH \& Grimes KG 1983. Queensland geology: a companion volume to the 1:2,500,000 scale geological map (1975), Geological Survey of Queensland Publication 383

de Caritat P \& Cooper M 2011. National geochemical survey of Australia: the geochemical atlas of Australia, Geoscience Australia Record 2011/20, Geoscience Australia, Canberra.

Doutch HF 1979. Major structural elements of Australia. In: Earth science atlas of Australia, Bureau of Mineral Resources, Geology and Geophysics, Canberra.

Drexel JF, Preiss WV \& Parker AJ 1993. The geology of South Australia, Geological Survey of South Australia, Bulletin 54

Earth Sciences History Group 2010. Thematic issue: snapshots of the geological program covering the whole of Australia, Geological Society of Australia ESHG Newsletter 41.
Edgeworth David TE 1911. Notes on some of the Chief Tectonic Lines of Australia [part of a Presidential Address]. Journal and Proceedings of the Royal Society of New South Wales: 45, 4-60.

Finlayson DM 2008. A geological guide to Canberra region and Namadgi National Park, Geological Society of Australia (ACT Division), Canberra.

Geological Society of Australia 1971. Tectonic map of Australia and New Guinea, 1: 5M, Geological Society of Australia, Sydney.

Geological Survey of Western Australia 1990. Geology and mineral resources of Western Australia, Memoir 3, Geological Survey of Western Australia, Perth.

Geoscience Australia 2001. Palaeogeographic atlas of Australia. www.ga.gov.au/meta/ANZCW0703003727.html

Gunn P (ed) 1997. Thematic issue: airborne magnetic and radiometric surveys, AGSO Journal of Australian Geology and Geophysics 17.

Harris PT \& Whiteway T 2011. Global distribution of large submarine canyons: geomorphic differences between active and passive continental margins. Marine Geology 285, 69-86.

Hoatson DM, Claoué-Long JC \& Jaireth S 2008. Guide to using the 1:5000 000 scale map of Australian Proterozoic mafic-ultramafic magmatic events, Geoscience Australia Record 2008/15, Geoscience Australia, Canberra.

Johnson DP 2009. The geology of Australia, 2nd edn, Cambridge University Press, Port Melbourne.

Lymburner L, Tan P, Mueller N, Thackway R, Lewis A, Thankappan M, Randall L, Islam A \& Senarath U 2011. 250 metre dynamic land cover dataset of Australia, version 1 Geoscience Australia, Canberra.

McKenzie N, Jacquier D, Isbell R \& Brown K (ed) 2004. Australian soils and landscapes: an illustrated compendium, CSIRO Publishing, Collingwood.

National Library of Australia 2007. Australia in maps: great maps in Australia's history from the National Library's collection National Library of Australia, Canberra.

Plumb KA 1979. The tectonic evolution of Australia. Earth Science Reviews 49, 205-249.
Ross S 2010. A chronicle of change: AusGeo News celebrates 20 years. AusGeo News, December 2010, 100. www.ga.gov. au/ausgeonews/ausgeonews201012/chronicle.jsp

Scheibner E 1996, 1998. Geology of New South Walessynthesis, Geological Survey of New South Wales Memoir 13, Geological Survey of New South Wales, Maitland.

Shaw RD, Wellman P, Gunn P, Whitaker AJ, Tarlowski C \& Morse M 1995. Australian crustal elements (1:5,000,000 scale map) based on the distribution of geophysical domains (v 1.0), Australian Geological Survey Organisation, Canberra.

\section{Australian lithosphere}

Clitheroe G, Gudmundsson O \& Kennett BLN 2000.

The crustal thickness of Australia. Journal of Geophysical Research 105, 13697-13713.

Kennett BLN, Salmon M, Saygin E \& AusMoho Working Group 2011. AusMoho: the variation of Moho depth in Australia. Geophysical Journal International 187, 946-958.

Hillis RR \& Müller RD (eds) 2003. Evolution and dynamics of the Australian Plate, Geological Society of Australia Special Publication 22.

\section{Australia through time}

Australian Journal of Earth Sciences 2008. Thematic issue: geochronology of Australia, Australian Journal of Earth Sciences 55(6/7)

Betts PG \& Giles D 2006. The 1800-1100 Ma tectonic evolution of Australia. Precambrian Research 144, 92-125.

Betts PG, Giles D, Schaefer BF \& Mark G 2007. 1600-1500 Ma hotspot track in eastern Australia: implications for Mesoproterozoic continental reconstructions. Terra Nova 19, 496-501.

Bishop P \& Pillans B (eds) 2010. Australian landscapes, Geological Society of London Special Publication 346.

Cawood PA 2005. Terra Australis Orogen: Rodinia breakup and development of the Pacific and Iapetus margins of Gondwana during the Neoproterozoic and Paleozoic. Earth-Science Reviews 69, 249-279.

Cawood PA \& Korsch RJ 2008. Assembling Australia: Proterozoic building of a continent. Precambrian Research $166,1-396$ 
Champion DC, Kositcin N, Huston DL, Mathews E \& Brown C 2009. Geodynamic synthesis of the Phanerozoic of Eastern Australia and implications for metallogeny, Geoscience Australia Record 2009/18, Geoscience Australia, Canberra.

Fujioka T \& Chappell J 2010. History of Australian aridity: chronology in the evolution of arid landscapes. In: Australian landscapes, Bishop P \& Pillans B (eds), Geological Society,

London, Special Publication 346, 121-139.

Giles D, Betts PG \& Lister GS 2004. 1.8-1.5-Ga link between the North and South Australian Cratons and the Early-Middle Proterozoic configuration of Australia. Tectonophysics 380, 27-41.

Gray DR \& Foster DA 2004. Tectonic review of the Lachlan Orogen: historical review, data synthesis and modern perspectives. Australian Journal of Earth Sciences 51, 773-817.

Great Barrier Reef Marine Park Authority 2007. Great Barrier Reef Climate Change Action Plan 2007-2011. www.gbrmpa.gov.au/corp_site/key_issues/climate_change/ management_responses

Hawkesworth CJ, Dhuime B, Pietranik AB, Cawood PA, Kemp AIS \& Storey CD 2010. The generation and evolution of the continental crust. Journal of the Geological Society 167 , 229-248.

Hoffman P 1991. Did the breakout of Laurentia turn Gondwanaland inside-out? Science 252, 1409-1412.

Huston DL, Blewett RS \& Champion DC 2012. Australia through time: a summary of its tectonic and metallogenic evolution. Episodes: in press.

International Commission on Stratigraphy 2009. International stratigraphic chart. www.stratigraphy.org/ upload/ISChart2009.pdf

Korsch RJ, Kositcin N \& Champion DC 2011. Australian island arcs through time: geodynamic implications for the Archean and Proterozoic. Gondwana Research 19, 716-734.

Laurie J (ed) 2009. Geological timewalk, Geoscience Australia, Canberra.

Le Heron DP 2011. Sea ice-free conditions during the Sturtian glaciation (early Cryogenian), South Australia. Geology 39, 31-34.
Lisiecki LE \& Raymo ME 2005. A Pliocene-Pleistocene stack of 57 globally distributed benthic $\delta^{18} \mathrm{O}$ records. Paleoceanography 20, PA1003.

López-Gamundí OR 2010. Late Paleozoic glacial events and postglacial transgressions in Gondwana, Geological Society of America Special Papers 468

Moss PT \& Kershaw AP 2000. The last glacial cycle from the humid tropics of northeastern Australia: comparison of a terrestrial and a marine record. Palaeogeography, Palaeoclimatology, Palaeoecology 155, 155-176.

Myers JS, Shaw RD \& Tyler IM 1996. Tectonic evolution of Proterozoic Australia. Tectonics 15, 1431-1446.

Neumann NL \& Fraser GL (eds) 2007. Geochronological synthesis and time-space plots for Proterozoic Australia, Geoscience Australia Record 2007/06, Geoscience Australia, Canberra.

Pisarevsky SA, Wingate MTD, Powell CM, Johnson S \& Evans DAD 2003. Models of Rodinia assembly and fragmentation. In: Proterozoic East Gondwana: supercontinent assembly and breakup, Yoshida M, Windley BE \& Dasgupta S (eds), Geological Society, London, Special Publication 206, $35-55$.

Siddall M, Chappell J \& Potter E-K 2006. Eustatic sea level during past interglacials. In: The climate of past interglacials, Sirocko F, Litt T, Claussen M \& Sanchez-Goni M-F (eds), Elsevier, Amsterdam, 74-92.

Squire RJ, Campbell IH, Allen CM \& Wilson CJL 2006. Did the Transgondwanan supermountain trigger the explosive radiation of animals on Earth? Earth and Planetary Science Letters 250, 116-133.

van Ufford AQ \& Cloos M 2005. Cenozoic tectonics of New Guinea. AAPG Bulletin 89, 119-140.

Veevers JJ (ed) 2000. Billion-year earth history of Australia and neighbours in Gondwanaland, GEMOC Press, Sydney.

Veevers JJ 2006. Updated Gondwana (Permian-Cretaceous) earth history of Australia. Gondwana Research 9, 231-260.

Wingate MTD, Pisarevsky SA \& Evans DAD 2002. A revised Rodinia supercontinent: no SWEAT, no AUSWUS. Terra Nova 14, 121-128. 